\title{
MICROCLIMA EM CAFEZAL (Coffea arabica L.): TEMPERATURA DO AR E DAS FOLHAS
}

\section{LUIZ LONARDONI FOLONI}

Orientador: NILSON AUGUSTO VILLA NQVA

Tese apresentada à Escola Superior de Agricultura "Luiz de Queiroz", da Universidade de São Paulo, para obtenção do título de Doutor em Sólos e Nutrição de Plantas

\section{PIRACICABA}

Estado de São Paulo-Brasil

Novembro, 1977 
Dedico à

GISEIA, minha esposa e. MARIANA, minha filha 
...A gente vai con+ra a corrente, Até não poder resistir,

Na volta do barco é que sente,

o quanto deixou de cumprir... 
Ao Dr. Nilson Augusto Viıla Nova, pelela amizade, dedicação e orientação no decorrer do curso de pós graduação.

Aos colegas do Departamento de Ciências Ambientais da Facuicąa de de Ciências Agronômicas de Botucatu, Dr. Antrrio Tubelis e Dr. Fernando José Lino do Nascimento, pelo incertivo e colabo ração no desenvolvimento e preparo deste trabalic.

Ao Sr. José Agenor Schiavon, peio apoio e colaboração na soluz ção de problemas de orden particular.

A Fundação de Amparo à Pesquisa do Estado de São Paulo pela concessão da bolsa de aperfeiçoamento e ao Instituto Brasilei ro do Café através do Grupo Executivo da Racionalização da Câ feicultura pelo auxílio financeiro.

Aos funcionários do Departamento de Cièncias Arbientais, em es pecial aos Srs. Joel Campos dos Santos, Antonio Aparecido Mar tins e Antonio Mariano da Silva, pela colaboraçẽo na obtenção dos dados de campo, datilografia e desenhos, e as demais pes soas que de uma forma ou de outra contribuiram para a realização deste trabalho.

Os meus sir eros agradecimentos 
4. MATERIAI E METODO $\ldots \ldots \ldots \ldots \ldots \ldots \ldots \ldots \ldots \ldots$

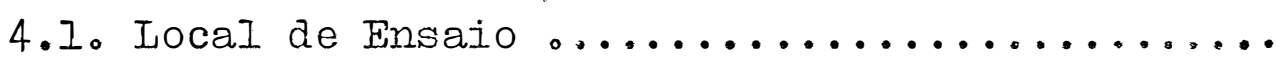

4.2. Medição da Temperatura do Ar .............

4.3. Medição da Temperatura das Folhas .........

4.4. Medição do Vento Percorrido .............

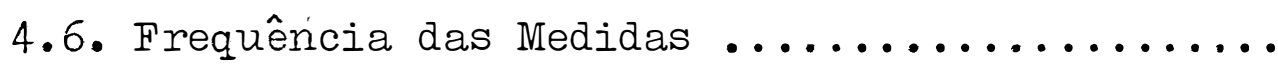

4.7. Cálculo da Temperatura do Ar Média Diária ...

5. RESULTADOS $\ldots \ldots \ldots \ldots \ldots \ldots \ldots \ldots \ldots \ldots \ldots \ldots \ldots \ldots \ldots \ldots \ldots \ldots$

5.1. Ensaio de Temperatura das Folhas ..........

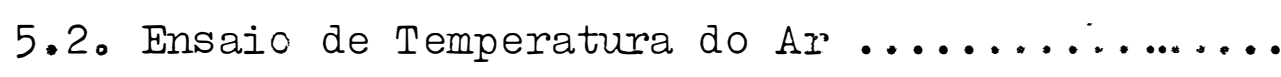

6. ANALISE E DISCUSS $\tilde{A} O \ldots \ldots \ldots \ldots \ldots \ldots$ 
-vii.

página

6.1.2. Desvios da Temperatura das F lhas em Relação à Temperatura do Ar .........

6.1.3. Relações entre a Temperaturas das Fo Ihas $a$ do $A r \ldots \ldots \ldots \ldots \ldots \ldots \ldots$

6.1.4. Relações entre as Diferenças da Terlpe ratura das Folhas e do Ar e Vento I'er

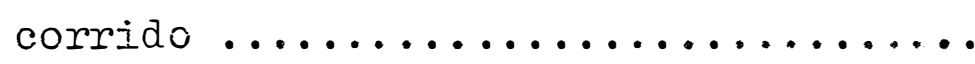

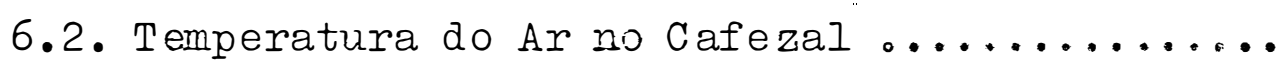

6.2.1. Curso Diário da Temperatura do Ar ...

6.2.2. Sequềncia Espacial da Temperatura do

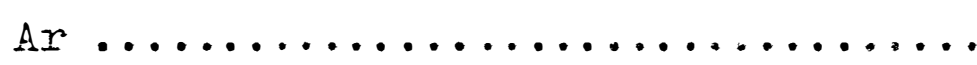

6.2.3. Sequência Diária dos Tautócronos Mé

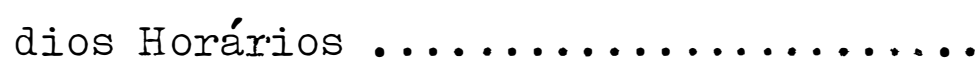

6.2.4. Perfis Verticais de Temperatura Média

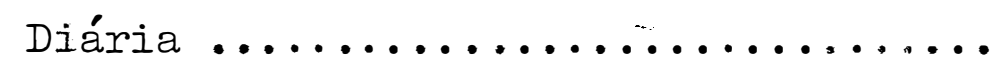

6.2.5. Análise de Variância da Temperatura Mé

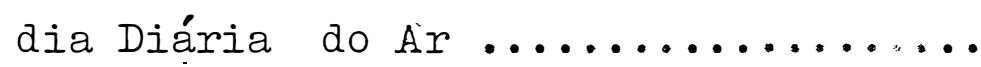

6.2.6. Perfis Verticais de Temperatura Máxima

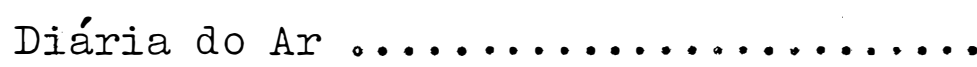

64

6.2.7. Análise de Variância da Temperatura Má

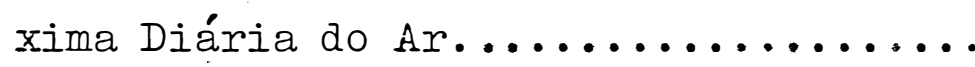

6.2.8. Perfis Verticais de Temperatura Rffma

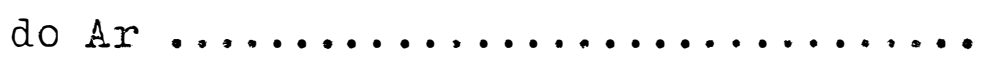


6.2.9. Análise de Variância da Temp catura Mín

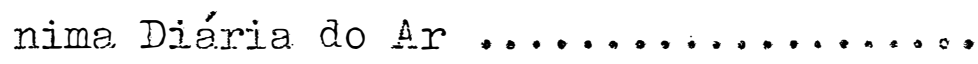

6.2.10.Estimativa da Temperatura Média Díria do Ar na Cultura ...............

6.3. Relações de Temperatura do Ar entre o Posto

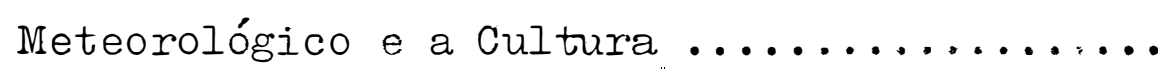

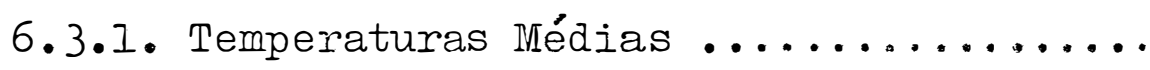

7. Conchusర్t $\ldots \ldots \ldots \ldots \ldots \ldots \ldots \ldots \ldots \ldots \ldots$

7.I. Sobre a Temperatura das Folhas ..........

7.2. Sobre a Temperatura do Ar no Cafezal .......

7.3. Sobre as Relações da Temperatura do Ar entre o Postọ Meteorológico e a Cultura ..........

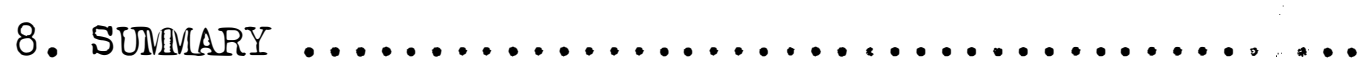




\section{IISTA DAS TABEIAS}

Tabela

página

1 Valores méaios mensais de precipjta 1968) e temperatura do ar (1959 a. 1968) para Botucatix-SP

2 Características físicas, químicas e granulomé tricas do solo do local de ensaio ............

3. Temperatura das folhas e do ar $\left({ }^{\circ} \mathrm{C}\right)$ para os três níveis de medição no período de 10 a ll/ 12/1971

4 Temperatura das folhas e do ar $\left({ }^{\circ} \mathrm{C}\right)$ para os três níveis de medição no período de 17 a 18/ 12/1971

5 Vento percorrido a $2 \mathrm{~m}$ acima da cultura ( $\mathrm{Km}$ ).. 32

6 Momentos de início de quatro formações de orva tho sobre a folhagem externa dos cafeeiros, nos três níveis de medição

7 Temperatura média horária do ar ( $\left.{ }^{{ }^{0}} \mathrm{C}\right)$ na cultú ra, nos cinco níveis de observação

8 Temperatura média diária do ar verdadeira( $\left(\frac{\mathrm{cm}}{}\right)$ na cultura $\left({ }^{\mathrm{C}}\right)$

9 Temperaturas extremas diárias do ar $\left({ }^{\circ} \mathrm{C}\right)$ nos

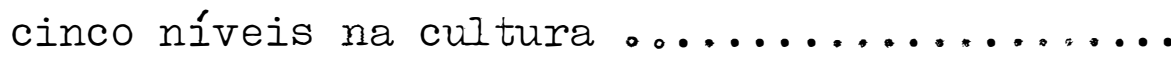

10 Temperatura média diária do ar $\left({ }^{\circ} \mathrm{C}\right)$ nos níveis na cultura, calculada segundo DEMET ( $\mathrm{T}_{\mathrm{ef}}$ ), IAC $\left(\mathrm{T}_{\mathrm{ce}}\right)$ e valores extremos $\left(\mathrm{T}_{\mathrm{cxn}}\right)$. 
11 Temperatura média diária ào ar no posto meteorológico calculada segundo DENErT $\left(\mathrm{T}_{\text {i. }}\right)_{\text {: }}$ IAC $T_{\text {pe }}$ e temperaturas extremas $T_{\text {pxn? }}$, temperetura máxima $\left(\mathrm{T}_{\mathrm{px}}\right)$ e temperatura mónira $\left(\mathrm{T}_{\mathrm{pn}}\right)$ s em

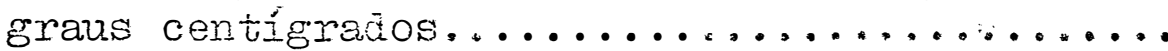

12 Temperatura do ar nos momentos em que a temperatura da folha $\left(T_{f}\right)$ e a do ar $\left(T_{\text {ar }}\right)$ foi extre ma

13 Coeficiente linear (a), angular (b) e correlação $(r)$, teste $t$ e significância ảe "r", e desvio padrão da regressão para as regressões lineares entre a temperatura da folina e do ar nos três níveis de medição ...........

14 Frequência de ocorrência diária dos gradiertes verticais de temperatura do ar na cultura ...

15 Análise de variância da temperatura média diá

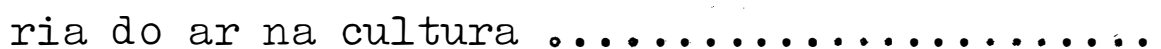

I6 Comparação do valores médios e extremos diá rios de temperatura do ar $\left({ }^{\circ} \mathrm{C}\right)$ na cultura pelo teste de DUNCAN ao nível de 5\% de probabilida de.

17 Análise de variância da temperctura máxima diá

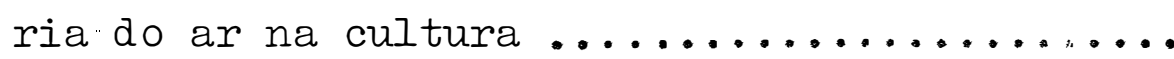

18 Análise de variância da temperatura nínime diá

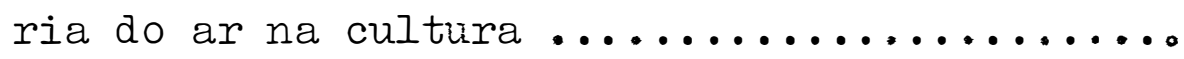


Tabela

página

19 Comparação entre a temperatura nédi diária da ar nos cinco níveis na cultura, pelo teste de DUNCAN ao núvel de 5\% de probabilialade......

20 Coeficiente Iinear (a), angular (b) e de correlação $(r)$, teste $t$ e significância de " $r$ " de desvio padrão, para as regressões linekres entre os valores estimados e verdadeiros da temperatura média do ar na cultura .........

21. Coeficiente linear (a), angular ( ) e de cor relação $(r)$, teste $t$ e significâncià de " $x$ " e desvio padrão para as regressões lineares en tre as temperaturas média verdadeira na cultu ra e as temperaturas médias no posto meteoroló gico segundo os modelos do DEVIET, IAC e as temperaturas extremas $\ldots \ldots \ldots \ldots \ldots \ldots \ldots \ldots$

22 Coeficiente linear (a), angular (b) e de cor relação $(r)$, teste $t$ e significância de " $r$ " de desvio padrão para as regressões lineares en tre as temperaturas extremas diárias observa das na cultura e no posto meteorológico. 
IISTA DAS FIGURAS

Figura

página

I Esquema da troca de energia entre a planta e

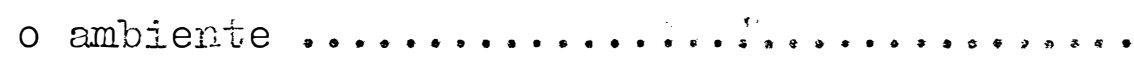

2. Relação méaia entre temperatura da folha e do ar para 40 culturas diferentes .........

3 Localização geográfica do município de Butü catu: dentro das zonas ecológicas aptas para a cafeicultura no Estado de São Paulo .....

4 Mapa plani-altimétrico da região de Botuca tu-SP, mostrando parte da Estação Experimen. tal de Botucatu, onde as áreas assinalades em negrito indicam a localização do posto Ine teorológico ( $p$ ) e o local de ensaio (c) ...

5 Detaliies do psicrômetro de aspiração no Ie vantamento dos perfis de temperatura do ar.

6 Curso da temperatura das folhas e do ar no nível de $0,2 \mathrm{H} . \ldots \ldots \ldots \ldots \ldots \ldots \ldots . . \ldots \ldots$

7 Curso da temperatura da folha e do ar no rí vel de $0,4 \mathrm{H} \ldots \ldots \ldots \ldots \ldots \ldots \ldots \ldots \ldots$

8 Curso da temperatura das folhas e do ar rio nível de $0,6 \mathrm{H}$

9 Temperaturas extremas da folha e do ar nos três níveis da cultura ................

10 Histograma dos desvios entre a temperatura das folhas e a temperatura do ar para os três níveis de observação na cultura ...... 
11 Diagraina de dispersão da temperatura das fo. Ihas e do ar e equações lineares de regressão

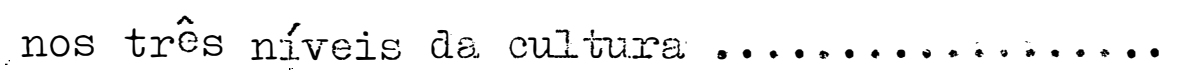

12 Diagrama de distribuição dos desvios entre a temperatura das folhas e do ar em função do

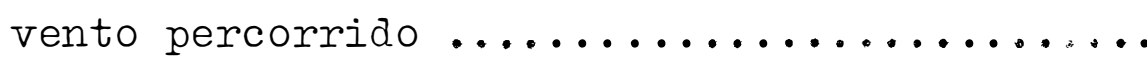

13 Curso diário dos valores médios horários da temperatura do ar no cafezal em cinco níveis de medição..$\ldots \ldots \ldots \ldots \ldots \ldots \ldots \ldots$

14 Sequência espacial da temperatura média horá

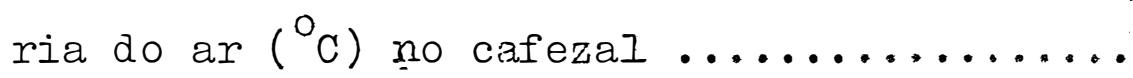

15 Sequência diária dos tautócronos médios de

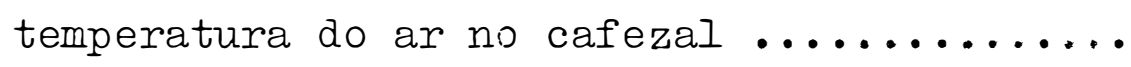

16 Perfis verticais de temperatura média diária e média de ensaio $\left({ }^{\circ} \mathrm{C}\right)$ na cultura em relação à temperatura no nível $1, \mathrm{OH} \ldots \ldots \ldots \ldots \ldots$.

17 Perfis verticais de temperatura máxima diária do ar na cultura

18 Perfis verticais de temperatura mínima diária

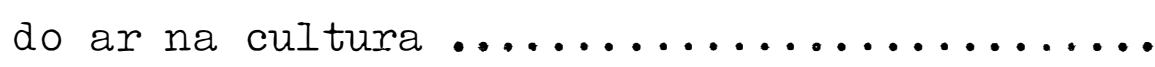

19 Histogramas dos desvios entre os valores esti mados e verdadeiros da temperatura módia do

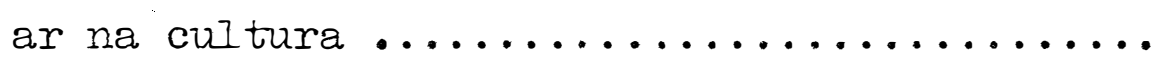


20 Histogramas dos desvios das tempera uras do ar médias diárias: calculados a partir de observações no posto meteoroíǵgico, em relẹ. ção à temperatura do ar média verdadeira,

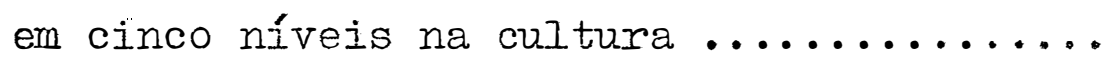

21 Histogramas dos desvios de temperaturas $\mathrm{X}$ tremas na cultura em relação ao posto meteo.

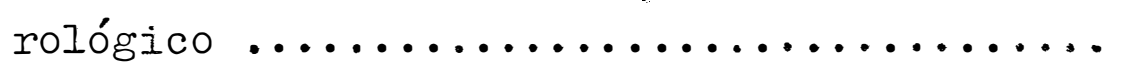


•xit.

IIISTA DE FOTOGRAEIAS

Fotografia

página

I Aspecto de um psicrômetro de aspiraçäo instalado na cultura .............

22

2

Vista da instalação da unidade de meị. ção de temperatura do ar na cultura . .

22 
Este trabalho estuda o regime térmico das fo Thas e do ar em uma cultura de café, com a finalidede de esta belecer relações de condições térmicas entre a cultura e o pos to meteorológicó.

A temperatura das folhas do cafeeirc foi medi da, em três níveis, com termo-elementos de cobre-constantana, inseridos na nervura principal das folhas. A temperatura do ar foi medida, em cinco níveis, com psicrômetros de aspiração, de termômetros de mercúrio。

A temperatura das folhas do cafeeiro foi maior que a do ar circundinte durante o período diumo, e menor no período noturno. Ela pode ser estimada a partir da temperatura do ar, através de equações lineares de regressão.

A temperatura do ar na cultura aumentoi com a altura durante a noite e diminuiu durante 0 ia. as inversões dos gradientes ocorreram das 08 às 10 horas e das 16 às 18 ho ras.

A região da cultura onde ocorreu o maior aqueci 
mento abrange de $20 \%$ a $40 \%$ da altura das plantas.

Em termos diários, a temperatura média do ar de cresceu com a altura na cultura, a temperatura máxima do ar decresceu e a temperatura mínima do ar cresceu. Era consequên cia, a amplitude térmica decresceu cóm a altura.

A temperatura do ar média diária verdadeira da cultura pode ser estimada, através de equações lineares de re gressão, em função da temperatura média calculada pelos mode Ios do DENET, do IAC ou das temperaturas extremas, a partir de leituras efetuadas na cultura ou no posto meteorológico. 
2. INTRODUÇÃO

o conhecimento das condições micrometeorológi cas das culturas agrícolas é urna das modernas ferramentas com que a Agronomia conta para o aumento de produtividade. Atingese esse objetivo porque é o arbiente físico das culturas que condiciona o rendimento fotossintético, a absorção de água e de minerais, o aparecimento de pragas e de doenças,

A medição dos parâmetros micrometeorológicos é uma tarefa onerosa, que consome muito tempo e que exige pessoal especializado e material específico. Para contomar essas dificuldades, procura-se estabelecer modelos matemáticos pelos quais possa se determinar as condições micrometoorológicas das culturas a partir de dados meteorológicos, coletados rotinei ramente, O estabelecimento aessas relações permite avaliar si tuações micrometeorológicas passadas, para exnicar fatos pregressos, bem como atuar rotineiramente sobre a cultura.

A finalidade deste trabajho é contricuir ao es tudo micrometeorológico da cuitura cafeeira, levantanáo as con dições térmicas reinantes em um cafezal, plantado em Botucatu$\mathrm{SP}$, e determinando os modelos que permitam avaliar climatolo 
gicamente a temperatura no interior da cultura.

o parâmetro temperatura foi o escolhido para es te estudo por constituir-se no principal fator limitante da cultura. Elegeu-se a cultura do café pelo fato do Brasil destą car-se como o maior produtor de café do mundo e suas exportações, embora considerando-se outras fontes de divisas, serem ainda de capital importância para o país. 


\section{REVISÃO BIBLIOGRAFICA}

Uma planta livremente exposta à atnosfera, com adequada disponibilidade de nutrientes e água, ten o rendimen to de seu processo fotossintético controlado pela temperatura (BURKHOLDER, 1936)。A temperatura do processo é a do protoplas ma das plantas, que pode ser estimada pela temperatura das fo Ihas。

A taxa fotossintética líquida em café depende da abertura dos estomatos, que é govemada pela disponibilida de de água no solo e pela ação combinada da radiação solar e temperatura das folhas. ALVIN e HAVIS (1954) encontraram que, durante a estação seca os estomatos permaneciam em sua maioria completamente fechados. Na estação churosa, em dias cobertos, permaneciam completamente abertos e em dias sem nebulosidade eles começavam a se fechar muito cedo, apresentando pequena a bertura no fim da tarde. NUNES et alii (1968) mostraram clara mente que a taxa fotossintética máxima oco re ne condição par ticular em que a concentração intema de $\mathrm{CO}_{2}$ é igual a zero.

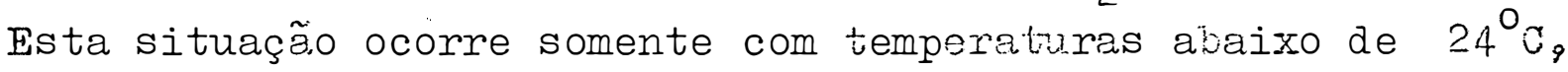
com uma intensidade de radias, ão maior que $0,15 \mathrm{cal} / \mathrm{cm}^{2} \cdot \mathrm{min}$, va 
Ior facilmente atingido em conãições de campo. Aciria de $24^{\circ} \mathrm{C}$, a concentração estomatal de $\mathrm{CO}_{2}$ cresce lirearmente a uma taxa de 20 ppm por ${ }^{\circ} \mathrm{C}$. As taxas máximas de fotossíntesse são menores acima de $24^{\circ} \mathrm{C}$ como consequência da maior concentração de come da maior resistência totaI a cifus̃̃o. HEATH e OKCHARD (1957) ve rificaram que a concentração de dióxido de carbono no interior da folha de café aumenta de forma logarítinica até $30^{\circ} \mathrm{C}$, e ain da mais rapidamente entre $30^{\circ} \mathrm{C}$ e $35^{\circ} \mathrm{C}$ 。

A medição da temperatura das folhas exige equi pamento de alto custo, pessoal especializado e cuidados contí nuos para não se alterar a geometria das folhas em torno do 10 cal de medida.(IDIE, 1968)。 Em consequência, os pesquisadores utilizam a temperatura do ar em substituição a temperatura da folha, na interpretação de resultados fisiológicos. Entretanto também nắo se prodecem medições de temperatura do ar no inte rior da cultura. Seria então conveniente estabelecer-se um es quema que permitisse a estimativa da temperatura das folhas do café utilizando-se dados climatológicos de observação roti neira。

A temperatura de uma folha ou órgão vegetal é consequência da interação da planta com o meio ambiente. Sua temperatura é controlada através dos processos de radiação, transpiração, conveç̧ão e condução térmica (GATES, 1965), con forme a Figura 1. Estes processos variam continiamente em im portância no estabelecimento da temperatura das folhas no de correr do dia e da noite. 
.07 .

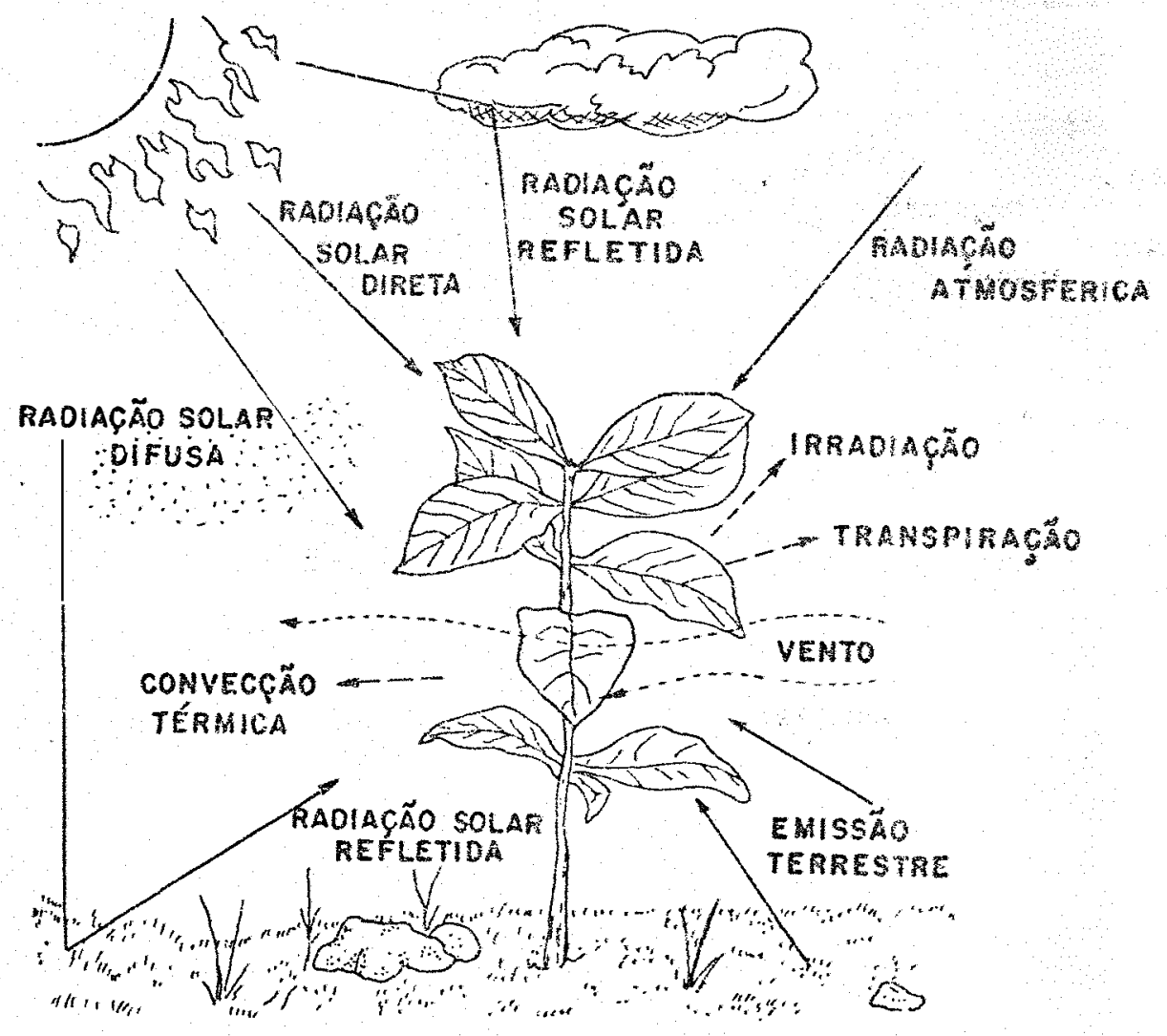

Figura 1. Esquema da troca de energia entre a pianta e 0 ambi ente。

Fonte: GATES(1965).

LINACRE (1964) comparando os resultados de 40 pesquisas realizadas com diferentes culturas, em diversas par tes do mundo, verificou que existe una tendência para a igual dade entre a temperatura do ar e da folha ao rejor de $33^{\circ} \mathrm{C}$. Em temperaturas inferiores, as folhas tenden a se apresentar mais aquecidas que o ar. Em tomperaturas maiores, estha tende a ser mais fria que o ar, conforme a Figura 2。 
.08.

rais do balanço de energia das folhas, confirnou o valor méáio obtido por LINACRE (I964), e coinentou que i temperatura máxima de qualquer superfície úmida, incluindo plantas, deveria ser ao redor de $33^{\circ} \mathrm{C}$. Folhas cujas temperatures excedan este valor estariam em đéfice de água。

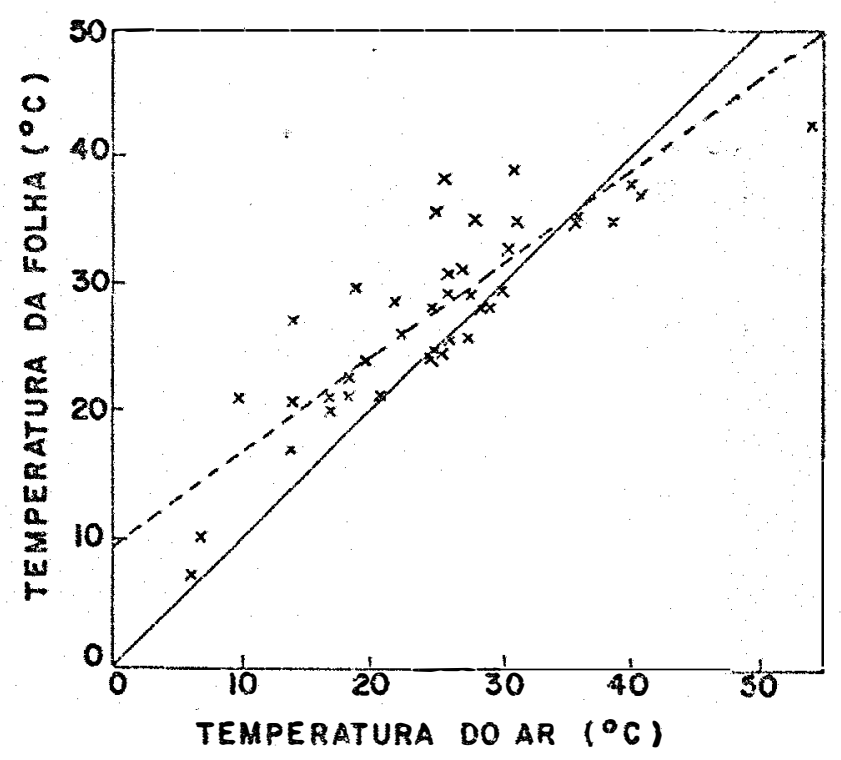

Figura 2. Relação média entre temperatura da folha e do ar pa ra 40 culturas diferentes。

Fonte: LINACRE (1964).

ANSARI \& LOONIS (1959) verificarami que folhas finas sofrem um aquecimento de $6^{\circ} \mathrm{C}$ a $10^{\circ} \mathrm{C}$ pelo efeito da luz solar em um minuto, e que folhas murchas ou trirgidas sofrem semelhantes variações de temperatura.

Estudos de temperatura de folha ae cafeeiro, em condições de campo, foram realizadas em alguns países. Smith em 1909, citado por KIRKPATRICK (1935), observou no Ceilão, sob 
condições de alta insolação e alta umidade do ary ao redor do meio do dia, que a temperatura de folhas verdes inteiramente expostas ao sol atinge entre $35^{\circ}$ a $45^{\circ} \mathrm{C}$, soralmente $10^{\circ}$ a $15^{\circ} \mathrm{C}$ acima da temperatura do ar na plantação. As maiores diferenças entre temperatura da folha e do ar coorreram anties do meio do dia, mas as maiores teuperaturas das folinas cerca de uma hora depois. A passagem de uma nuvem causou una rápida queda da or dem de $10^{\circ} \mathrm{C}$, embora a temperatura da folha permanecesse entre 3 a $5^{\circ} \mathrm{C}$ acima da temperatura do ar, mesmo após o sol ter se obscurecido por uma hora ou mais.

Verificou ainda que folhas sombreadas tinham $\underline{u}$ ma temperatura de 1 a $2{ }^{\circ} \mathrm{C}$ maior que a do ar circundante no pe ríodo entre o meio dia e as 16 horas.

SANTOS et alii (1958) mediram a temperatura do ar e de folhas em mudas de cafeeiros, a pleno sol e sombrea das, durante um dia com nebulosidadé, um sem nebulosidade e nu ma noite de irradiação. As observações durante o dia mostraram que as temperaturas extremas observadas foram $38,5^{\circ} \mathrm{C}$ para fo Iha a pleno sol, enquanto a folha sombreada estava a $2 I^{\circ} \mathrm{C}$ e a do ar a $25^{\circ} \mathrm{C}$. A máxima à sombra ocorreu em momento diferente da máxima a pleno sol, atingindo o valor de $26,7^{\circ} \mathrm{C}$ quando a folha a pleno sol era de $33,3^{\circ} \mathrm{C}$ e a do ar $28,8^{\circ} \mathrm{C}$. As mínimas ocorreram simultaneamente e foram $11, l^{\circ} \mathrm{C}$ a pleno sol, $10,8^{\circ} \mathrm{C}$ a sombra e $13,1^{\circ} \mathrm{C}$ no ar。As diferenças de temperatura máximas observadas entre folha a pleno sol e ar de $13,0^{\circ} \mathrm{C}$ e folha co berta e ar de $-4,0^{\circ} \mathrm{C}$. Estes resultados foram obtidos em Piraci caba-SP, em dois dias distintos no mês de julho: As temperatu ras em noite de irradiação foram realizadas em Campos de Jor dão-SP, no mesmo mês. Observaram que a temperatura das folhas 
foi menor que a temperatura do ar durante a noite, com as dife renças variando de 0,3 a $2,4^{\circ} \mathrm{C}$, a medida que se aproximava do momento de ocorrência da temperatura mínima diária: Estas para a folha, foi de $-3,9^{\circ} \mathrm{C}$.

ORTOLANI (1973) cita que investigações realiza das pela Seção de Climatologia Agrícola do Instituto Agronômi co, em condições especiais de verão, mostram que a temperatura de folhas de cafeeiros atinge $50^{\circ} \mathrm{C}$. Fm Campinas foram medidas temperaturas de folhas de cafeeiros Caturra, com termopar em contacto com a superfície inferior de folhas expostas à radia ção solar direta. Durante os meses de fevereiro E março de197 foram selecionados dez dias em função dos máximos extremos de temperatura do ar。 Nesses dias foram registradas 156 ocor rências com temperaturas de folhas entre 40 e $45^{\circ} \mathrm{C}, 62$ entre 45,1 e $50,0^{\circ} \mathrm{C}$ e 6 entre 50,1 e $50,8^{\circ} \mathrm{C}$.

Como a temperatura do ar é de mais fácil medi ção, exige pessoal menos especializado e possibilita a sua me dição rotineira, em relação a temperatura das folhas, seria in teressante desenvolver-se um modelo pelo qual esta última pu desse ser estimada a partir da primeira。

Poucas são as medições da temperatura do ar no interior de cafezais com a finalidade primeira de se conhecer - regime térmico da cultura.

Excelente trabalho foi desenvolvido por KIRCKPA TRICK (1935), que estudou o microclima de uma cultura de café no Quênia, Africa Oriental. Pela pouca disponibilidade instru mental o autor procedia a medição em apenas doie pontos, nor malmente ao nível de 1,30 m acima do solo dentro e fora da cul 
tura. Realizou medições de temperatura do ar, da folha e do so Io, umidade do ar, velocidade do vento, poder evaporante do ar, precipitação e intensidade Iuminosa. Fstudou o efeito modi ficador da topografia, espaçamerto, colheita, sombreamento, quebra vento e cobertura do solo sọre os parâmetros meteoroló gicos medicos。

COSTA e SCHRODER (1956) realizaram medições de temperatura e umidade relativa do ar em cafezais não sombrea dos em Ribeirão Preto-SP e Matão-SP. Estes parâmetros foram re gistrados por termo-higrógrafos convencionais, em quatro ní veis, sendo dois no interior e dois acima da cultura. Simulta neamente eram feitas observações em um posto meteorológico pró ximo. Foram estudados duas séries de dados, ccrrespondentes a um período na estação seca e outro na chuvosa.

Compararam o curso da temperatura do ar das saias do\$ cafeeiros com o curso a dois metros acima das copas; estudaram a sequência diária dos perfis de sequência diária do ar e analisaram a distribuição da amplitude térmica diária com a altura. Análise semelhante foi feita para umidade relativa do ar. O regime e a distribuição da velocidade do vento foi a nalisada em sete níveis。

Os trabalhos de KIRCKPATRICK (1935) e COSTA e SCHRODER (1956) não esclarecem suficientemente o regime térmi co no interior da cultura. o primeiro porque não levou em con ta a distribuição vertical da temperatura no interior da cultu彑 ra e no segundo, como os próprios autores recorheceram, o equi pamento utilizado não era adequado para me içَ̃e microclimato lógicas. Seria conveniente que se fizesse um estudo mais abran 
gente do regime térmico no interior da cultura utilizando equi pamento específico.

Para dar uma maior amplitude de aplicação aos resultados, seria oportuno o estabelecimento de relações entre as condições microclimáticas da cultura com as condições macro climáticas locais. Tais relações permitiriam a utilização de todo o acervo de dados meteorológicos, de algumas dezenas de anos, em benefício de racíonalização da cultura.

o presente trabalho foi desenvolvido em função dos aspectos considerados nesta análise bibliográfica, com vis tas a contribuir para o melhor conhecimento do regime térmico da cultura. Os objetivos deste trabalho podem $s \in r$ resumidos nos seguintes Ítens:

- estudar o regime térmico das folhas do cafeei ro;

- estudar o regime térmico do ar na cultura;

- estabelecer um modelo de estimativa da tempe ratura das folhas do cafeeiro a partir da tem peratura do ar na cultura;

- estabelecer um modelo de estimativa da tempe rátura do ar na cultura a partir da temperatura do ar medida em um posto meteorológico. 
4. MATERIAL E INÉTODO

4.1. Local de Ensaio

o presente estuđo foi realizado ra Estação Expe rimental "Presidente Meãici" (antiga Estação 'Experimental de Botucatu), no município de Botucatu, definido pelas coordena das geográficas: altitude $815 \mathrm{~m}$, latitude $22^{\circ} 52^{\prime} \mathrm{s}$ e longitude $48^{\circ} 27^{\prime}$ W. Grw, conforme mostrado nas Figuras 3 e 4.

O clima de Botucatu pode ser considerado como sub-tropical chuvoso, que devido as tendências verificadas nos últimos anos, pode ser ind́icado como do tipo Cfo segundo a classificação de KUppen e BB'r segundo a classificação de Thomthwaite (SETZER, 1946)。

Os dados de precipitação pluviom crica mostram um total médio anual de $1314 \mathrm{~mm}$, conforme mostra a Tabela 1 .

A tendência observade é de ma ruativa regula ridade das precipitações anuais em tomo do valor médio, e que nos anos mais secos geralmente chove mais que $1000 \mathrm{~mm}$. A dis tribuição estacional das precipitações indica que $37 \%$ do total 


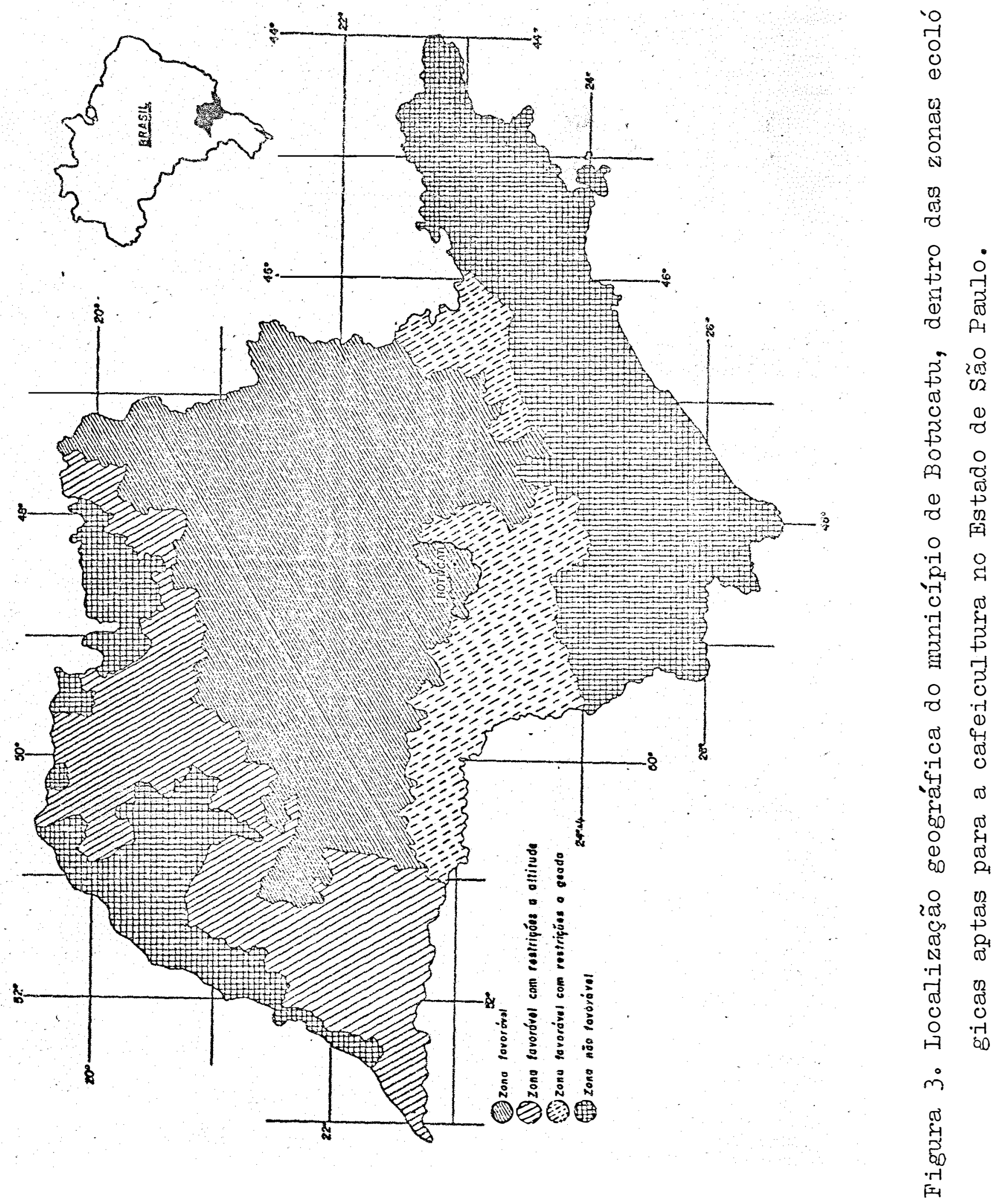




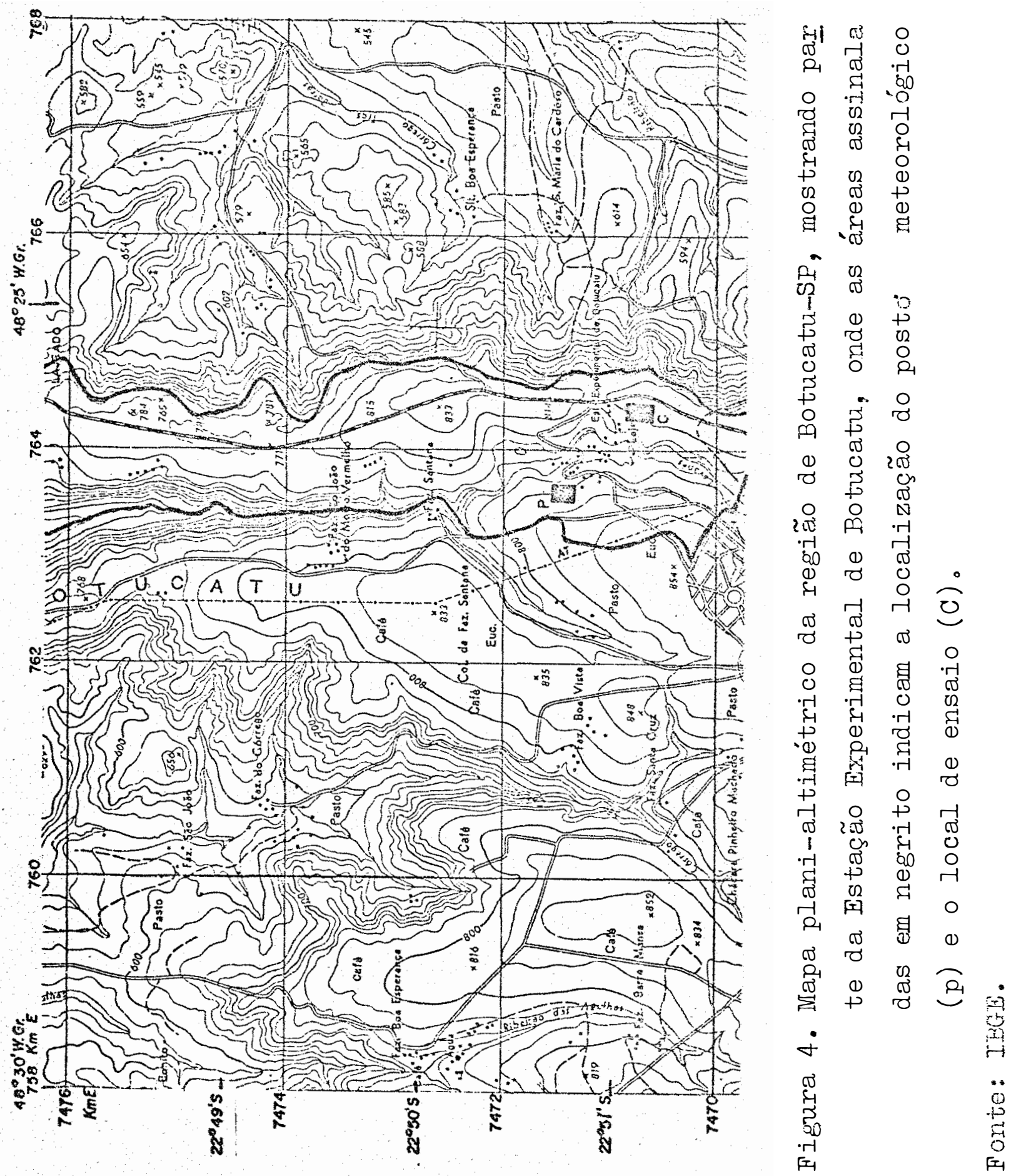




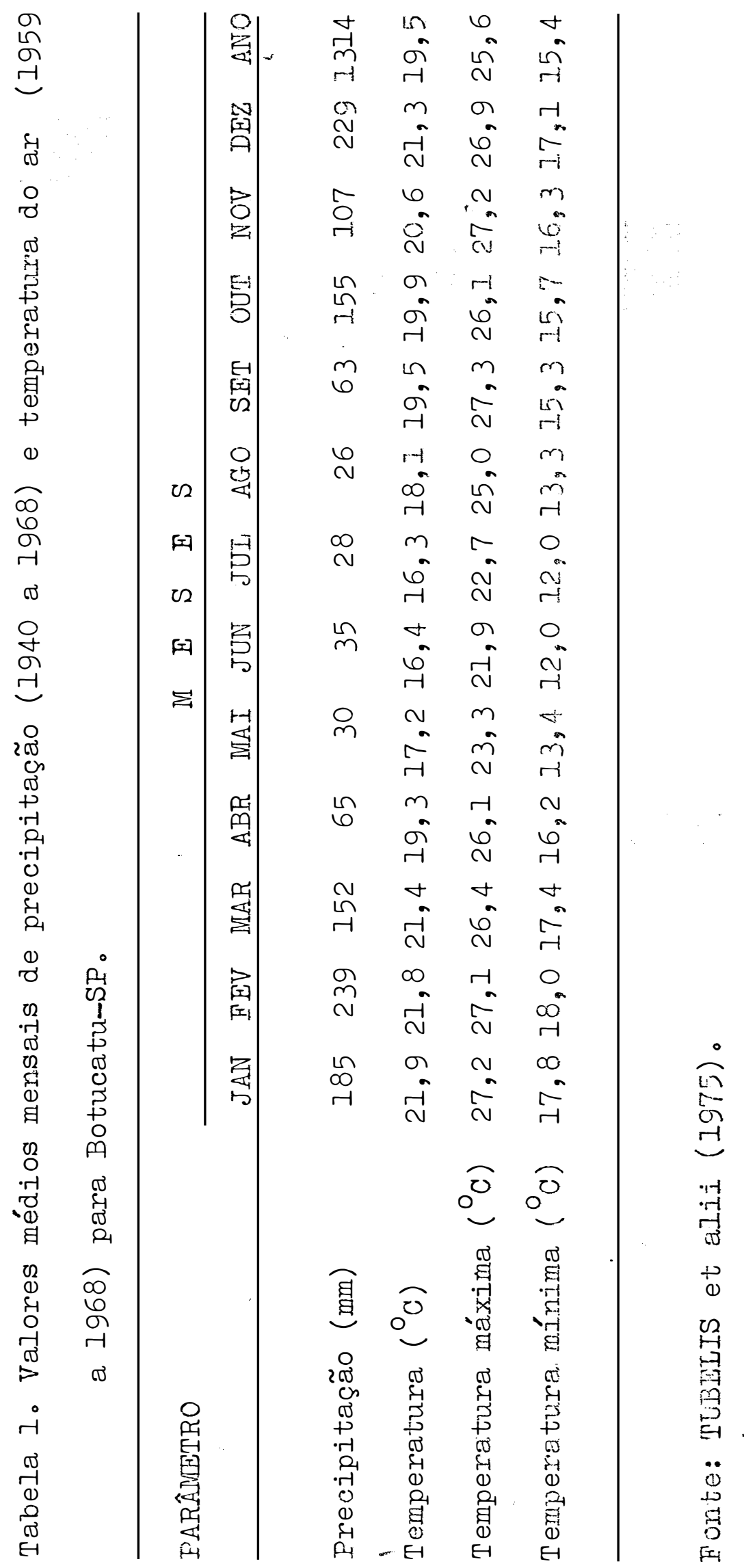


anual incide na primavera, $4.4 \%$ no verão, $10 \%$ no outono e $9 \%$ no inverno, caracterizando um período chuvoso de outubro a março e um período estival de abril a setembro.

A temperatura do ar apresenta um valcr médio a nual de $19,5^{\circ} \mathrm{C}$ sendo janeiro o mês mais quente com $21,9^{\circ} \mathrm{C}$ e jü tho o mês mais frio com $26,3^{\circ} \mathrm{C}$. Observa-se uma tendência da temperatura aumentar de juIho a janeiro, e decrescer de janei ro a julho。 Ocorrem 8 meses (setemtro a abril) em que a tempe ratura média é superior a temperatura média anual.

A temperatura média no período chuvoso é de $21,2^{\circ} \mathrm{C}$ e no período estival de $17,8^{\circ} \mathrm{C}$.

A análise dos dados médios de temreraturas 'ex tremas mostra que os valores médios anuais são $25,6^{\circ} \mathrm{C}$ e $15,4^{\circ} \mathrm{C}$ indicando uma amplitude térmica média anual de $10,2^{\circ} \mathrm{C}$ o curso da tempetratura mínima acompanha o curso da temperatura média, apresentando os menores valores em junho e julho $\left(12^{\circ} \mathrm{C}\right)$ e os maiores valores em fevereiro $\left(18,0^{\circ} \mathrm{C}\right)$ 。 o curso da temperatura máxima não segue o da temperatura média, apresentando um pata mar de setembro a abril, período no qual ela varia entre os va lores médios de 26,1 a $27,3^{\circ} \mathrm{C}$; decresce de abril a junho, quando alcança $21,9^{\circ} \mathrm{C}$ e aumenta de junho a setembro, $\mathrm{A}$ amplitude térmica apresenta maiores valores em agosto e setembro, perío do no qual são observados os maiores valores extremos absolu tos (TUBEIIS, et alii, 1975)。

Conforme é mostrado na Figura 3, o município de Botucatu-SP é considerado como uma regiãc apta para a cafei cultura

A cultura de café utilizada é da variedade "Mun 
do Novo", com oi.to anos de idade, plantado no espaçamerto de 3 x $2 \mathrm{~m}$, com 4 plantas por cova. As plant: z apresentavam uma altura méaiia cie $2,75 \mathrm{~m}$, com forma tronco-cônica, bem enīolha das, com diânetro médio de $2,00 \mathrm{~m}$ é $1,70 \mathrm{~m}$ respectivamente a $0,55 \mathrm{~m}$ e $1,65 \mathrm{~m}$ acima do solo. 0 Índice de cobertura de solo pela cultura era de aproximadamente $50 \%$.

O tipo de solo do local de ensaio é rerra Roxa Estruturada (TOSIN et alii, 1973). Os solos deste tipo sao de senvolvidos a partir de rochas eruptivas básicas sob relevo normal, onduiado, ber drenados e de cores avermeihadas. São, em geral, profundos, diminuindo a espessura à mećida que o re levo se torna mais acentuado, transitando para o litossol da unidade.Apresertam a sequência de horizontes: Ax - B2I - B22B23 - B3 - C. As características físicais, químices e granulomé tricas do solo do local de ensaio estão na Tabele. 2.

A cultura estava localizada em terreno de meia encosta, com declividade média de $8 \%$ e exposição oeste. As li nhas de plantas eram orientadas na direção norte-sul. A altitu de média do local de ensaio é de 800 metros, corforme pode ser visto na Figura 4. Esta mesma Figura mostra a localização do posto meteorológico, que dista aproximadamente 850 metros do local de ensaio, e apresenta uma altitude de 800 metros.

4.2. Medição da Temperatura do Ar

A temperatura do ar foi medicáa aucuvés de psicrô metros de aspiração forçada nos dois termômetros. Os termôme tros eram de coluna de mercúrio, com escala de $-15 \mathrm{a}+61^{\circ} \mathrm{C}$, e 


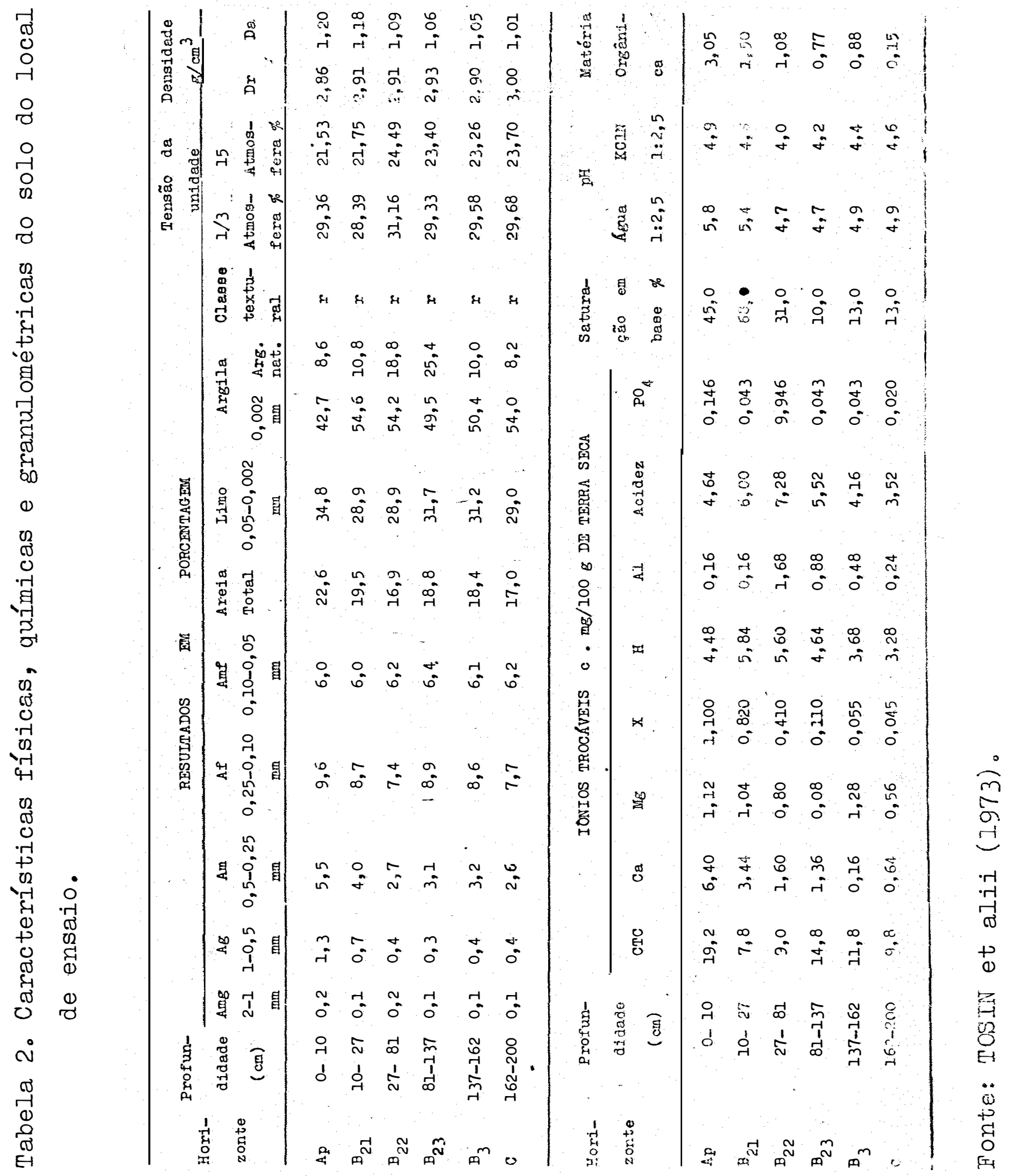


divisões de $0,2^{\circ} \mathrm{C}$, e foram protegidos da radiação solar direta por uma placa rótíca polida, instalada cima e distanciada de 3 cm dos tubos ae aspiração. Estes tubos foran racobertos com papel alumínio para eliminar a inciāencis de radiação difu sa e refletida. O psicrômetro utilizado esté rostrado em deta thes na Figura 5 .

A aspiração ae cada psicrômetro ŕo feita, à dis tância, pela ventoinha do próprio psicrômetro. A ligação do psicrômetro à ventoinha foi feita por duto plástizo flexível de $32 \mathrm{~mm}$ de diâmetro interno e 8 metros de compriaento. A fo tografia 1 mostra a instalação de um psicrômetro.

A unidade para medida da temperatira do ar cons tou de cinco psicrômetros, montados em haste única, e instala dos nas seguintes alturas acima do solo: 0,55 m, 1,10 m, 1,65 $\mathrm{m}, 2,20 \mathrm{~m}$ e 2,75m. Estas alturas corresponaiam aos níveis de $0,2 \mathrm{H} ; 0,4 \mathrm{H} ; 0,6 \mathrm{H} ; 0,8 \mathrm{H}$ e $1,0 \mathrm{H}$, onde $\mathrm{H}$ é a altura média das plantas. A unidade foi instalada no meio da rua, com os psicrô metros na horizontal, aspirando ar do lado poente das plantas, a uma distância média de $10 \mathrm{~cm}$ das folhas. As ventoinhas de as piração foram colocadas fora da linha de plantas om que efetua vam as medidas. A fotografia 2 mostra uma vista da unidade de međição de temperatura do ar.

4.3. Medição da Temperatura das Folhas

A medida da temperatura das folhas do cafeeiro foi feita através de terno-elementos de cobre-constantan AWG26, instalados na nervura principal das Iolnes, na sua face 

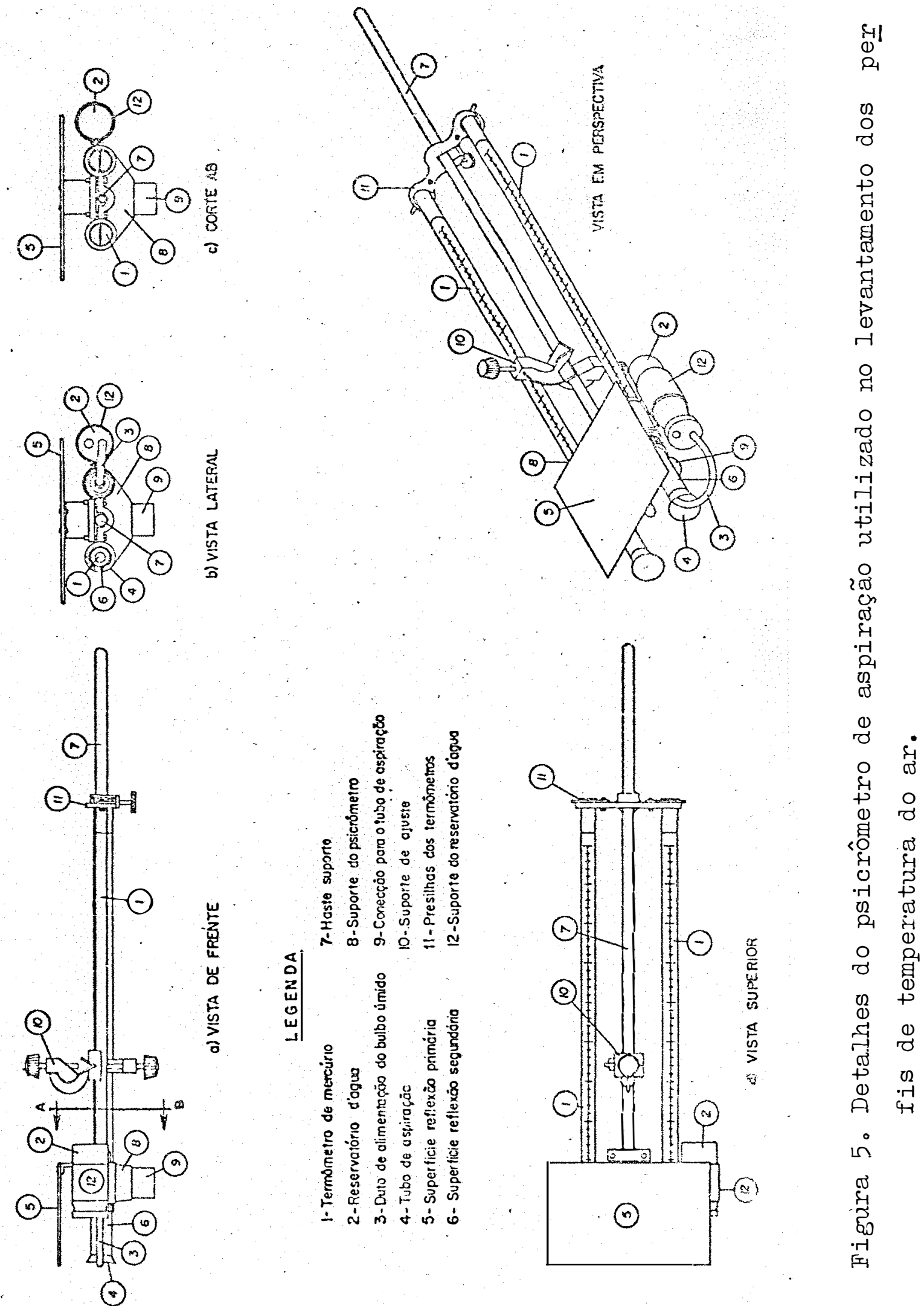


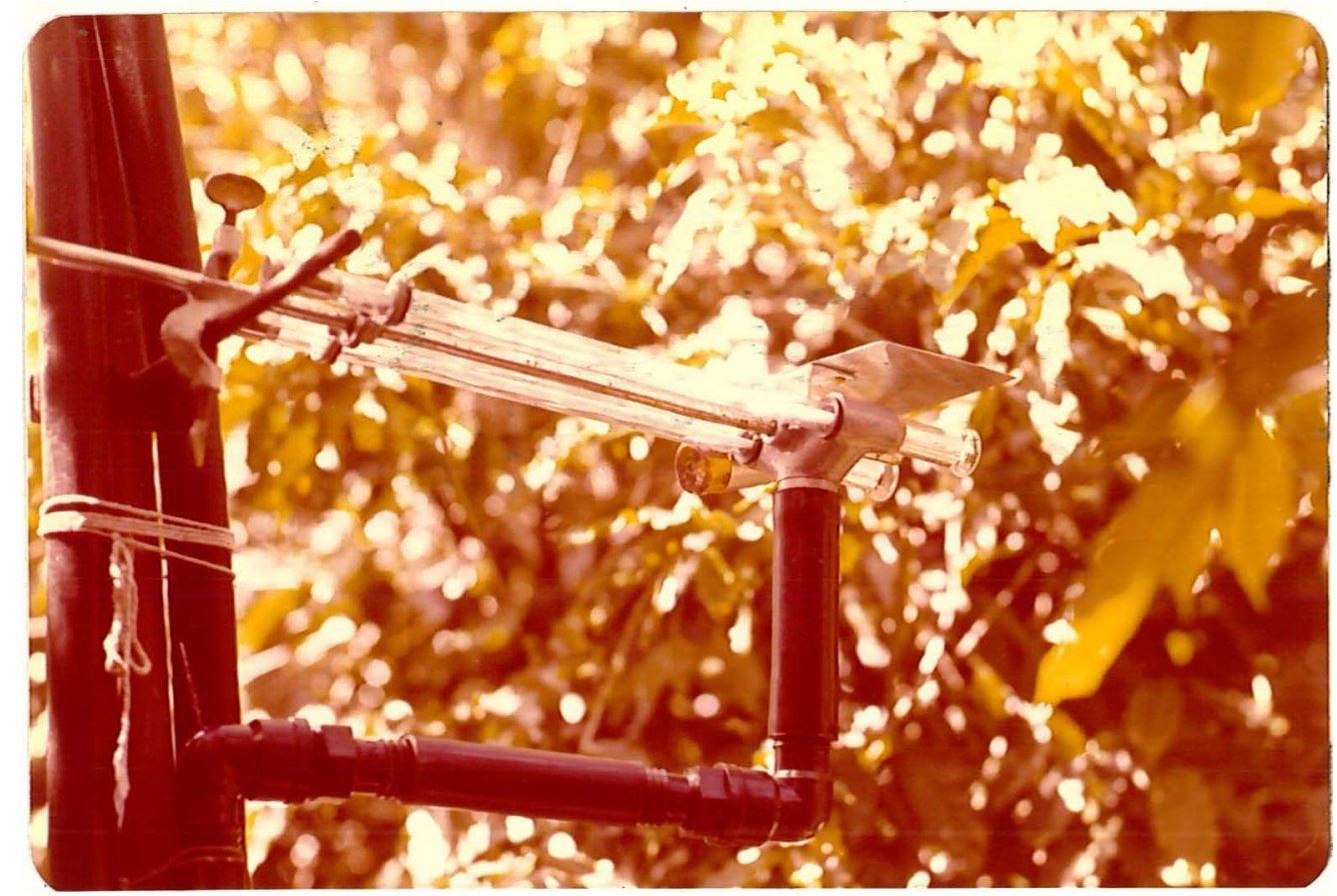

FCTOGRAFIA 1

Aspecto de um psicrômetro de aspiração instalado na cultura.

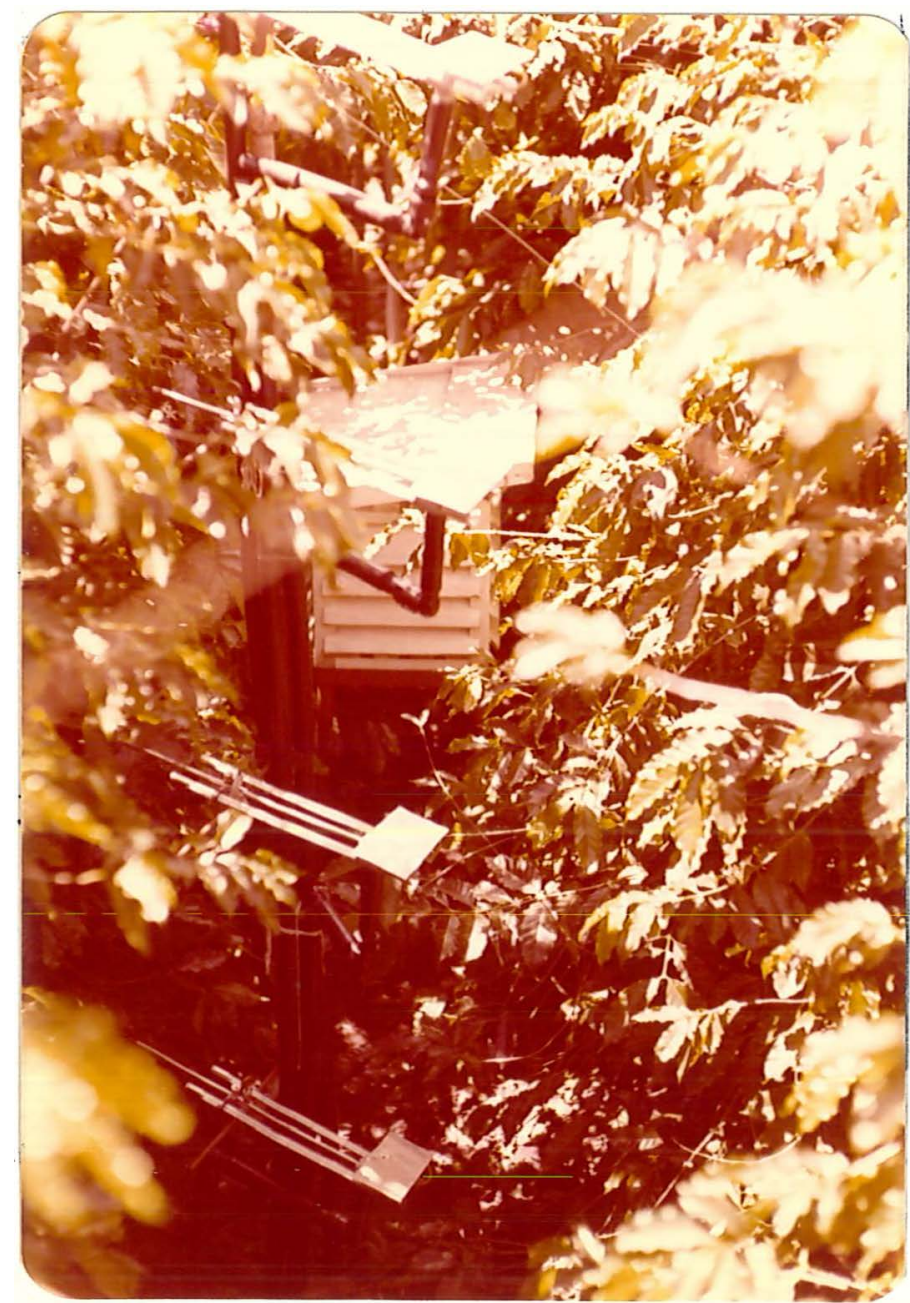

FOTOGRAFIA 2

Vista da instalaçäo da unidade de rnedição de temperatura do ar na culltura。 
dorsal。A

folhas nao poj elterada peia u tilização dos temo-elementos。 As rnediūas foram realizadas em folhas externas nos níveis de: $0,55 \mathrm{~m}(0,2 \mathrm{H}), 3,10 \mathrm{~m}(0,4 \mathrm{H})$ e $1,65 \mathrm{~m}(\mathrm{O}, 6 \mathrm{H})$ 。

A Ieitura das forças eletronotrizes foi feita a través de uma ponte potenciométrica, ra escala de 0 a 50 mili volts, divisão de urn miervvolt e precisão de 0,02\%。

A força eletromotriz lida $\left(\mathbb{E}_{\hat{\ell}}\right)$, eva corrigida da constante de calibração do elemento $\left(C_{i}\right)$ e aa força eletromo triz devida a difererça de temperatura da fonte fria em rela ção a $0^{O} \mathrm{C}\left(\mathrm{C}_{f}\right)$, utilizando-se a expressão:

$$
E_{c}=E_{\ell} \pm C_{i} \pm C_{I} \quad \ldots \ldots \ldots \text { (equação } I \text { ) }
$$

onde $E_{C}$ é a força eletromotriz corrigida。

A força eletromotriz corrigida era transformada em temperatura através de tabela de conversão, publicadas pelo NATIONAI BUREAU OF STANDARDS(NBS) dos Estados Unidos da Améri ca do Norte (WEAST, 1968/69)。

4.4. Medição do Vento Percorricio

O vento percorrido foi medico através de uin anemômetro totalizador, de três conchas hemisféricas para vento de 1 a $60 \mathrm{~m} / \mathrm{s}$, instalado a 2,00 m acima do níve médios das plantas. 
4.5. Posto Meteorológico

Foram utilizados dados de temperctira do ar, ob servados nos horários das 07, 09, 14 e 21 horas e das tempera turas extremas。

As leituras de temperatura do ar foram liaas com um psicrômetro de aspiração forçada, com termômotros de mercú rio em vidro e com divisões de $0,2^{\circ} \mathrm{C}$. As temperuturas extremas foram lidas com termômetros de máxima e de mónina, respectiva mente, de mercúrio em vidaro e álcool em vidro, jubos com divi sões de $0,2^{\circ} \mathrm{C}$.

4.6. Frequência das Niedidas

As leituras da temperatura das folras, da tempe ratura do ar e vento percorrido na cultura foram realizadas a cada trinta minutos。

Simultaneamente com as medições, eram fieitas ob servações visuais da formação de orvalho sobre ms folhas expos tas dos cafeeiros.

4.7. Cálculo da Temperatura do Ar Média Diária

A temperatura do ar média dirria roi calculada das seguintes formas: 
a) Procedendo a média de 48 leituras:

$$
t \bar{M}=\frac{\sum_{1}^{48} t_{i}}{48} \quad \ldots \ldots \ldots(\text { equação } 2)
$$

onde:

$$
\begin{aligned}
& t \vec{M}=\text { temperatura do ar média diária verdaảeira. } \\
& t_{\dot{i}}=\text { temperatura do ar observada no momento da leitura. }
\end{aligned}
$$

b) Utilizando o modelo do Departamento Nacional de Meteorologia (DEMET) ao Ministério da Agri cultura (BRASII, 1969):

$$
t_{F}=\frac{t_{O g}+2 T_{21}+t_{X}+t_{n}}{5} \ldots(\text { equação } 3)
$$

onde:

$$
\begin{aligned}
& t_{\mathrm{F}}=\text { temperatura do ar média diária, estimada segundo } \\
& \text { DENET. } \\
& t_{09}=\text { temperatura do ar observada às og horas locais。 } \\
& t_{2 I}=\text { temperatura do ar observada às } 21 \text { horas locaìs。 } \\
& t_{\mathrm{X}}=\text { temperatura do ar máxima do dia. } \\
& t_{n}=\text { temperatura do ar mínima do dia. }
\end{aligned}
$$


c) Uțilizardo o modelo do Instituto Agronômico de Campinas (IAC), da Secretarie da Agricuztu ra do Estado de São Paulo (Gowoy, 1957):

$$
t_{E} \frac{t_{07}+t_{14}+2 T_{21}}{4} \ldots(\text { equação } 4)
$$

onde:

$$
\begin{aligned}
& t_{\mathrm{F}}=\text { temperatura do ar média diária, estima segundo } \\
& \text { IAC. } \\
& t_{07}=\text { temperatura do ar observada às } 07 \text { horas locais。 } \\
& t_{14}=\text { temperatura do ar observada às } 14 \text { horas Iocais. } \\
& t_{21}=\text { tempere.tura do ar observada às } 21 \text { horas locais。 }
\end{aligned}
$$

d) Utilizanßo as temperaturas do ar extremas diá rias:

$$
t_{x n}=\frac{t_{x}+t_{n}}{2} \quad \ldots \ldots \ldots \text { (equação } 5 \text { ) }
$$

onde:

$$
\begin{aligned}
& t_{x n} \doteq \begin{array}{l}
\text { temperatura do ar média diária, estimada pelas } \\
\text { temperaturas extremas. }
\end{array} \\
& t_{x}=\text { temperatura do ar máxima do dia. } \\
& t_{n}=\text { temperatura do ar mínima do dia. }
\end{aligned}
$$


os Íraices $\underline{C}$ e $P$, incluídos na simbologia das temperaturas médias, indicam que os valon, se referem, respec tivamente, à medições na cultura ou no posto meteorológico.

4.8. Análises Estatísticas

A análise de variância dos dados ce temperatura do ar média diária no interior da cultura foi feita como bio cos ao acaso, onde os dias representavam os blocos e os níveis de medição os tratamerıos. As expressões utilizadas nesta aná lise são as propostas por GOMES: (1966).A verificição das mé dias diferentes foi feita pelo tesde de DUNCAN (coNES, 1966).

As equações lineares de regressão foram feitas pelo método dos quadrados mínimos (GONES, 1966)。 o cálculo do coeficiente de correlação linear " $r$ " e o teste de significân cia deste coeficiente pelo teste "t", foi Ieito segundo GRANER (1966)。 
.28.

5. RESULTADOS

5.1. Ensaio de Temperatura das Folhas

Os valores da temperatura das folhes e da tempe ratura do ar no interior da cultura, nos níveis de $0,2 \mathrm{H}, 0,4 \mathrm{H}$ e $0,6 \mathrm{H}$, encontram-se nas Tabelas 3 e 4 .

Os valores do vento percorrido a $2,0 \mathrm{~m}$ acima do topo da cultura encontram-se na Tabela 5.

Na. Tabela 6 são mostrados os momentos de início de formação de orvalho. No período de 17 a 18 de dezembro de 1971 não ocorreu o fenômeno。

5.2. Ensaio de Temperatura do Ar

Os valores de temperatura do ar, observados em cinco níveis no interior da cultura, no perí do de 16 de março de 1971 a 05 de setembro de 1972, estão contidos nas Tabelas de 7 a 10. Os valores de ternperatura média horária para o pe ríodo estão contiaos na Tabela 7. A temperatura nédia diária 
verdadeira esté inseriáa na Tabela 8. Os valores extremos diá rios de temperatura do ar estão reunidos na Tabelí 9. Os valo res de temperatura média diária do ar calculados segundo o DENE'T, IAC e valores extremos, estão contidos na labela 10。

Os valores médios e extremos diáxios de tempera tura do ar no posto meteorológico, observados durante os ensa ios, estão contidos na Tabela 11 . 
Tabela 3. Temperatura das folhas e do ar $\left({ }^{\circ} \mathrm{C}\right)$ para os três níveis de medição no período de 10 . 11/12/1971.

\begin{tabular}{|c|c|c|c|c|c|c|}
\hline \multirow{3}{*}{ Hora } & \multicolumn{6}{|c|}{$\mathbb{N}$} \\
\hline & \multicolumn{2}{|c|}{$\mathrm{O}, 2 \mathrm{H}$} & \multicolumn{2}{|c|}{$0,4 \mathrm{H}$} & \multicolumn{2}{|c|}{$0,5 \mathrm{H}$} \\
\hline & Folhe & Ar & Folha & Ar & Fclha & Ar \\
\hline $17 \mathrm{hOO}$ & 22,7 & 23,8 & 23,2 & 23,6 & 22,9 & 23,6 \\
\hline $17 \mathrm{~h} 30$ & 23,2 & 23,8 & 23,4 & 23,6 & 23,6 & 23,6 \\
\hline $18 \mathrm{ho0}$ & 22,0 & 23,6 & 22,4 & 23,8 & 22,6 & 23,8 \\
\hline $18 \mathrm{~h} 30$ & 20,5 & 22,0 & 20,2 & 22,2 & 21,1 & 22,4 \\
\hline $19 \mathrm{hoO}$ & 19,4 & 20,3 & 18,9 & 20,2 & 19,9 & 21,0 \\
\hline $19 \mathrm{~h} 30$ & 19,2 & 20,0 & 18,9 & 20,2 & 20,4 & 20,8 \\
\hline $20 \mathrm{hOO}$ & 19,2 & 20,0 & 18,9 & 20,2 & 20,4 & 20,8 \\
\hline $20 h 30$ & 19,5 & 20,0 & 19,2 & 20,2 & 19,9 & 20,8 \\
\hline $21 \mathrm{hO} 00$ & 19,5 & 20,0 & 19,4 & 20,4 & 20,9 & 20,8 \\
\hline $2 \ln 30$ & 18,7 & 19,8 & 19,2 & 20,2 & $=0,6$ & 20,6 \\
\hline $22 \mathrm{hOO}$ & 19,6 & 19,4 & 19,0 & 19,8 & 20,6 & 20,3 \\
\hline $22 h 30$ & 19,5 & 19,7 & 18,7 & 20,0 & 20,1 & 20,3 \\
\hline $23 \mathrm{hOO}$ & 19,5 & 19,4 & 19,4 & 19,6 & 19,1 & 19,8 \\
\hline $23 \mathrm{~h} 30$ & 19,5 & 19,4 & 19,4 & 19,6 & 19,1 & 19,8 \\
\hline OOhOO & 19,5 & 19,6 & 18,7 & 19,8 & $3.9,9$ & 20,0 \\
\hline oon 30 & 20,2 & 19,8 & 19,7 & $-20,2$ & 20,6 & 20,4 \\
\hline Olhoo & 20,7 & 19,7 & 19,9 & 20,0 & 20,6 & 20,3 \\
\hline $0 \ln 30$ & 18,7 & 19,2 & 18,7 & 19,2 & 19,4 & 19,6 \\
\hline $02 \mathrm{hOO}$ & 18,5 & 19,0 & 18,4 & 19,2 & 18,9 & 19,6 \\
\hline $02 \mathrm{~h} 30$ & 19,0 & 18,4 & 17,9 & 18,4 & 18,9 & 18,6 \\
\hline O $3 \mathrm{hOO}$ & 18,2 & 18,4 & 18,9 & 18,4 & 18,4 & 18,6 \\
\hline $03 \mathrm{~h} 30$ & 19,7 & 19,0 & 18,7 & 19,2 & 19,6 & 19,5 \\
\hline O4h00 & 19,0 & 19,0 & 19,2 & $1.8,9$ & 19,1 & 19,0 \\
\hline $04 \mathrm{~h} 30$ & 19,0 & 19,0 & 19,4 & 19,0 & 19,6 & 19,0 \\
\hline $05 \mathrm{~h} 00$ & 19,0 & 18,8 & 19,2 & 18,9 & 19,1 & 19,0 \\
\hline $05 \mathrm{~h} 30$ & 18,7 & 18,6 & 18,2 & 18,5 & 18,4 & 18,6 \\
\hline 06h00 & 19,7 & 19,0 & 19,4 & 19,0 & 19,6 & 19,4 \\
\hline $06 \mathrm{~h} 30$ & 20,0 & 19,2 & 19,9 & 19,2 & 20,1 & 19,6 \\
\hline O7h00 & 20,5 & 19,4 & 20,4 & 19,6 & 20,1 & 19,6 \\
\hline $07 h 30$ & 22,0 & 20,4 & $2 I, 7$ & 20,2 & 21,4 & 20,4 \\
\hline
\end{tabular}


Tabela 4. Temperatura das folhas e do ar $\left({ }^{\circ} \mathrm{C}\right)$ para os três níveis de medição no período de 17 a 18 de dezembro de 1971.

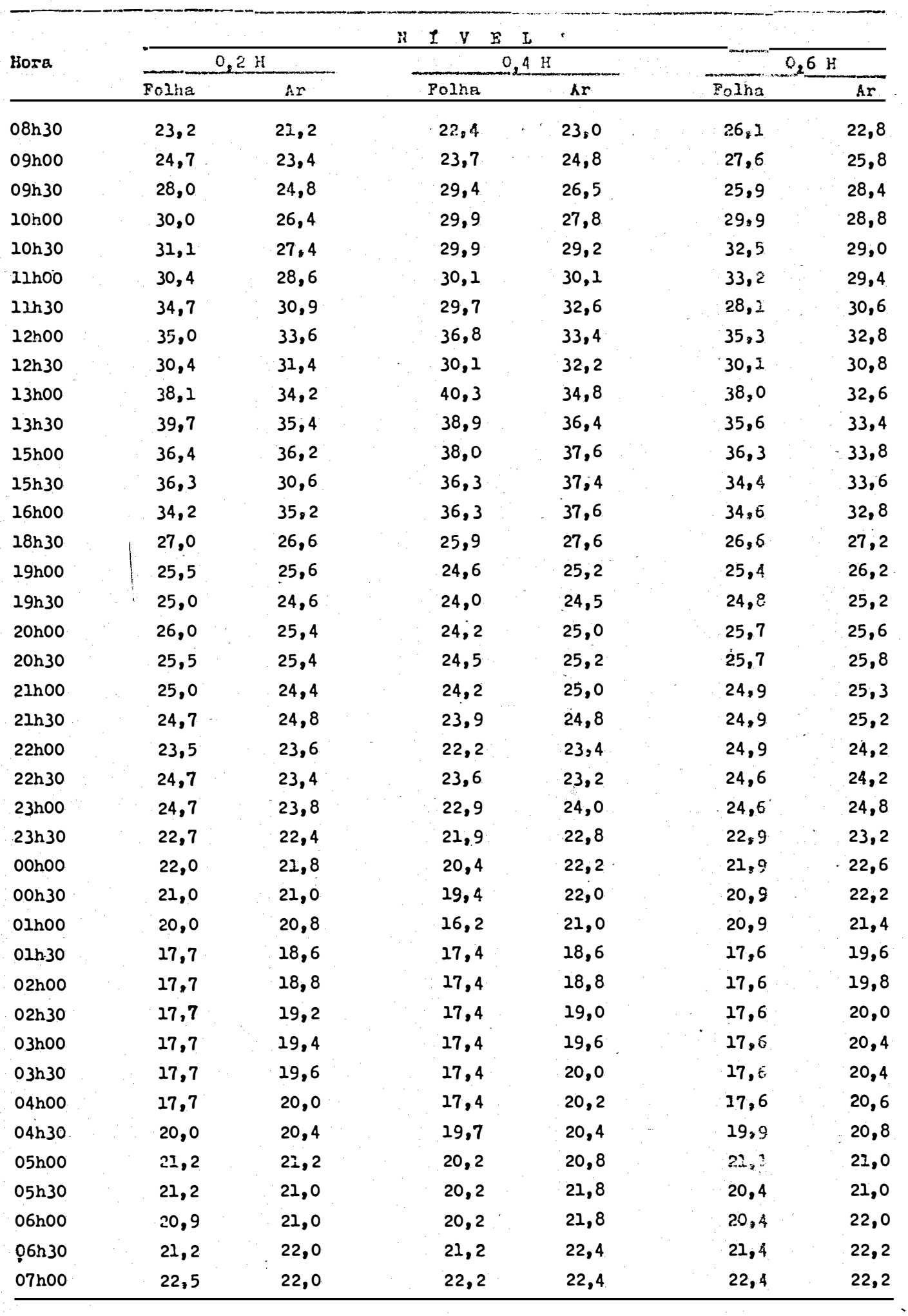




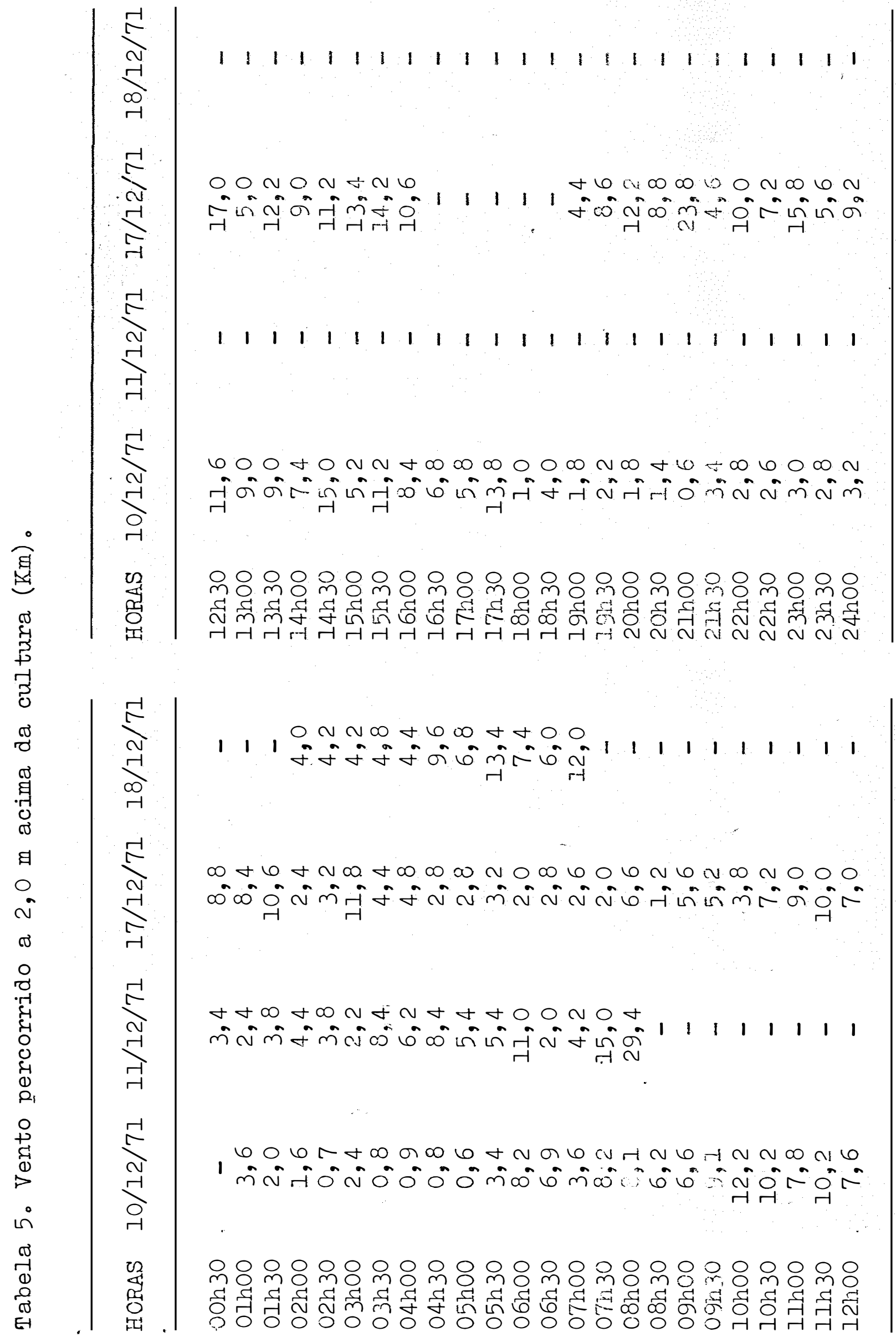


.33.

Tabela 6. Momertos de início de quatro formações de orvalho so bre a folhagem extema dos cafeeiros, nos três ní veis de medição。

\begin{tabular}{lllll}
\hline \multirow{2}{*}{ NOITE } & \multicolumn{3}{c}{ NIVEL } \\
\cline { 3 - 5 } & $0,2 \mathrm{H}$ & $0,4 \mathrm{H}$ & $0,6 \mathrm{H}$ \\
\hline
\end{tabular}

\begin{tabular}{rrrrr} 
& I & $2 \ln 30$ & $22 \mathrm{~h} 30$ & $23 \mathrm{~h} 00$ \\
10 a II/I2/7I & II & $22 \mathrm{hl} 5$ & $00 \mathrm{~h} 00$ & $23 \mathrm{~h} 45$ \\
& III & $02 \mathrm{~h} 00$ & $02 \mathrm{~h} 30$ & $03 \mathrm{~h} 00$ \\
& IV & $02 \mathrm{~h} 50$ & $03 \mathrm{hl} 5$ & $03 \mathrm{~h} 45$ \\
& & & & \\
\hline
\end{tabular}


Tabela 7. Temperatura média horária do ar $\left({ }^{\circ} \mathrm{C}\right)$ na cultura, nos cirıco níveis de observação.

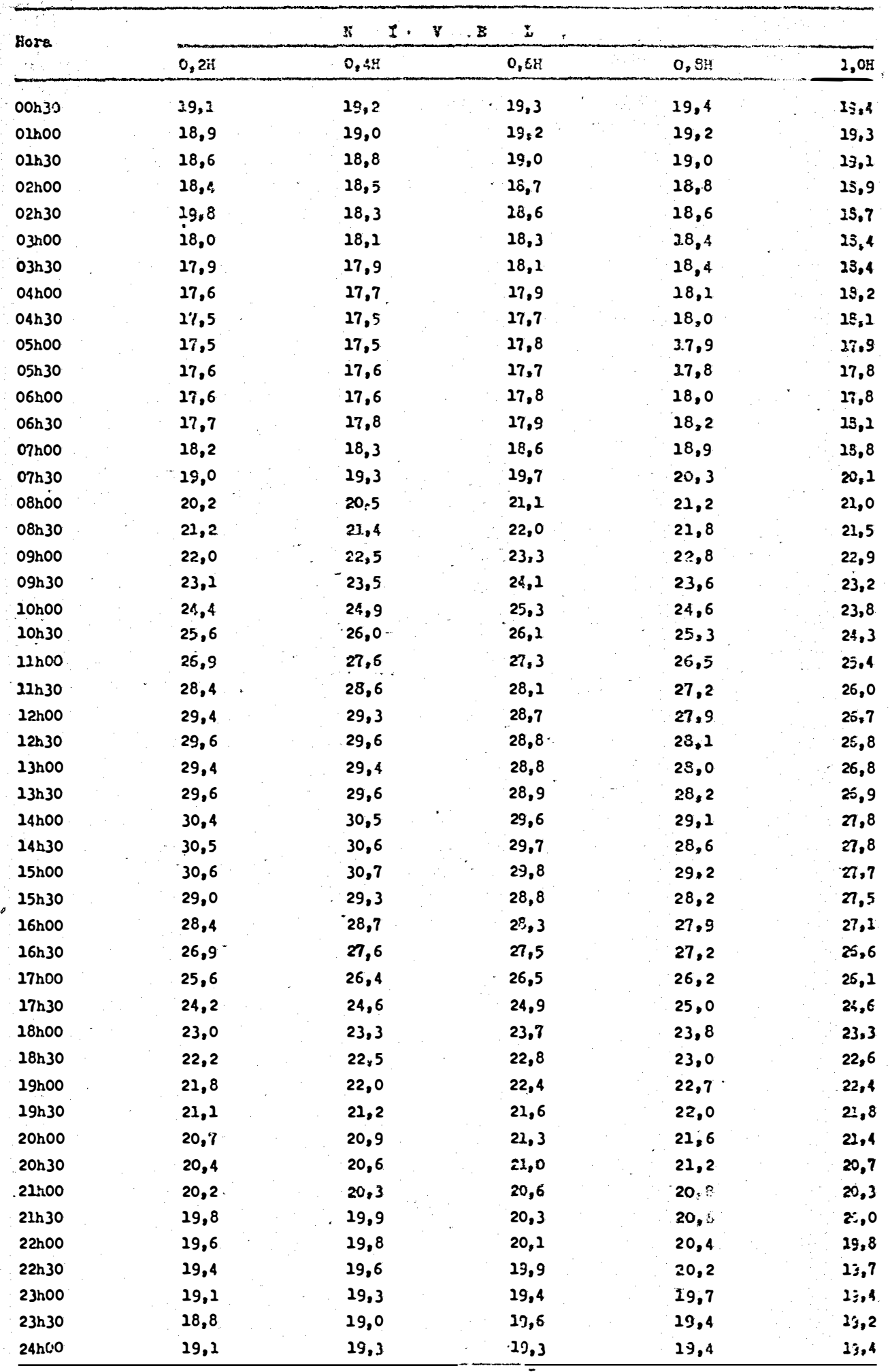


.35.

Tabela 8. Temperatura média diária do ar verảeira (Tcm) na cultura $\left({ }^{\circ} \mathrm{C}\right)$ 。

\begin{tabular}{llllll}
\hline & \multicolumn{5}{c}{ NIVEI } \\
\cline { 2 - 6 } DIA & $0,2 \mathrm{H}$ & $0,4 \mathrm{H}$ & $0,6 \mathrm{H}$ & $0,8 \mathrm{~F}$ & $1,0 \mathrm{H}$ \\
\hline & & & & \\
$16 / 03$ & 25,3 & 25,6 & 25,6 & 25,7 & 25,3 \\
$17 / 03$ & 25,6 & 26,1 & 26,0 & 26,3 & 25,7 \\
$18 / 03$ & 26,3 & 26,7 & 26,6 & 26,5 & 25,9 \\
$19 / 03$ & 24,6 & 24,8 & 25,4 & 25,4 & 24,8 \\
$26 / 03$ & 22,1 & 22,2 & 22,2 & 21,9 & 21,4 \\
$30 / 03$ & 22,0 & 22,3 & 22,3 & 22,0 & 21,4 \\
$31 / 03$ & 22,8 & 22,9 & 22,8 & 22,7 & 22,3 \\
01/04 & 22,6 & 22,7 & 22,7 & 22,7 & 22,2 \\
02/04 & 22,1 & 22,4 & 22,4 & 22,2 & 21,7 \\
$10 / 12$ & 22,5 & 22,6 & 22,7 & 22,9 & 22,3 \\
$18 / 01$ & 24,5 & 24,7 & 25,0 & 25,2 & 24,8 \\
01/09 & 12,1 & 12,5 & 12,9 & 12,3 & 12,2 \\
05/09 & 17,6 & 17,7 & 18,0 & 17,3 & 17,5 \\
\hline MEDIA & 22,3 & 22,6 & 22,7 & 22,5 & 22,1 \\
\hline
\end{tabular}


Ta ela 9. Temperaturas extremas diárias do ax ( ${ }^{0} \mathrm{C}$ ) nos cinco níveis na cultura.

\begin{tabular}{|c|c|c|}
\hline \multirow{3}{*}{ DIA } & MLAXIMA $\quad(\mathrm{TCX})$ & MfNINA (TCn) \\
\hline & NIVEI & NIVEL \\
\hline & $\mathrm{O}, 2 \mathrm{H} \mathrm{O}, 4 \mathrm{H} \mathrm{O}, 6 \mathrm{H} \mathrm{O,8H} \mathrm{I,OH}$ & $\mathrm{O}, 2 \mathrm{H} \quad \mathrm{O}, 4 \mathrm{H} \quad 0,6 \mathrm{H} \mathrm{O}, 8 \mathrm{H} \mathrm{I,OH}$ \\
\hline $16 / 03$ & $36,8 \quad 36,8 \quad 35,0 \quad 33,8 \quad 32,5$ & $20,020,220,621,021,0$ \\
\hline $17 / 03$ & $35,8 \quad 36,4 \quad 35,0 \quad 36,1 \quad 33,2$ & $19,819,820,020,220,3$ \\
\hline $18 / 03$ & $35,8 \quad 35,6 \quad 35,7 \quad 33,6 \quad 32,4$ & $21,621,821,821,821,0$ \\
\hline $19 / 03$ & $35,635,634,533,832,0$ & $19,019,019,019,219,0$ \\
\hline $26 / 03$ & $32,332,131,030,427,6$ & $17,6 \quad 17,517,7 \quad 17,817,6$ \\
\hline $30 / 03$ & $31,531,630,329,027,9$ & $17,517,417,617,817,7$ \\
\hline $31 / 03$ & $30,831,230,028,828,4$ & $18,018,218,318,418,4$ \\
\hline $01 / 04$ & $32,232,631,129,928,2$ & $17,417,4 \quad 17,617,817,6$ \\
\hline $02 / 04$ & $31,431,431,129,8.27,8$ & $17,217,217,4.17,617,4$ \\
\hline $10 / 12$ & $31,430,830,231,028,2$ & $17,417,417,617,817,7$ \\
\hline $18 / 01$ & $33,8 \quad 33,4 \quad 33,1 \quad 32,1 \quad 30,7$ & $17,617,617,618,218,6$ \\
\hline $01 / 09$ & $22,622,421,621,019,6$ & $6,2 \quad 6,4 \quad 6,6 \quad 6,8 \quad 7,2$ \\
\hline
\end{tabular}




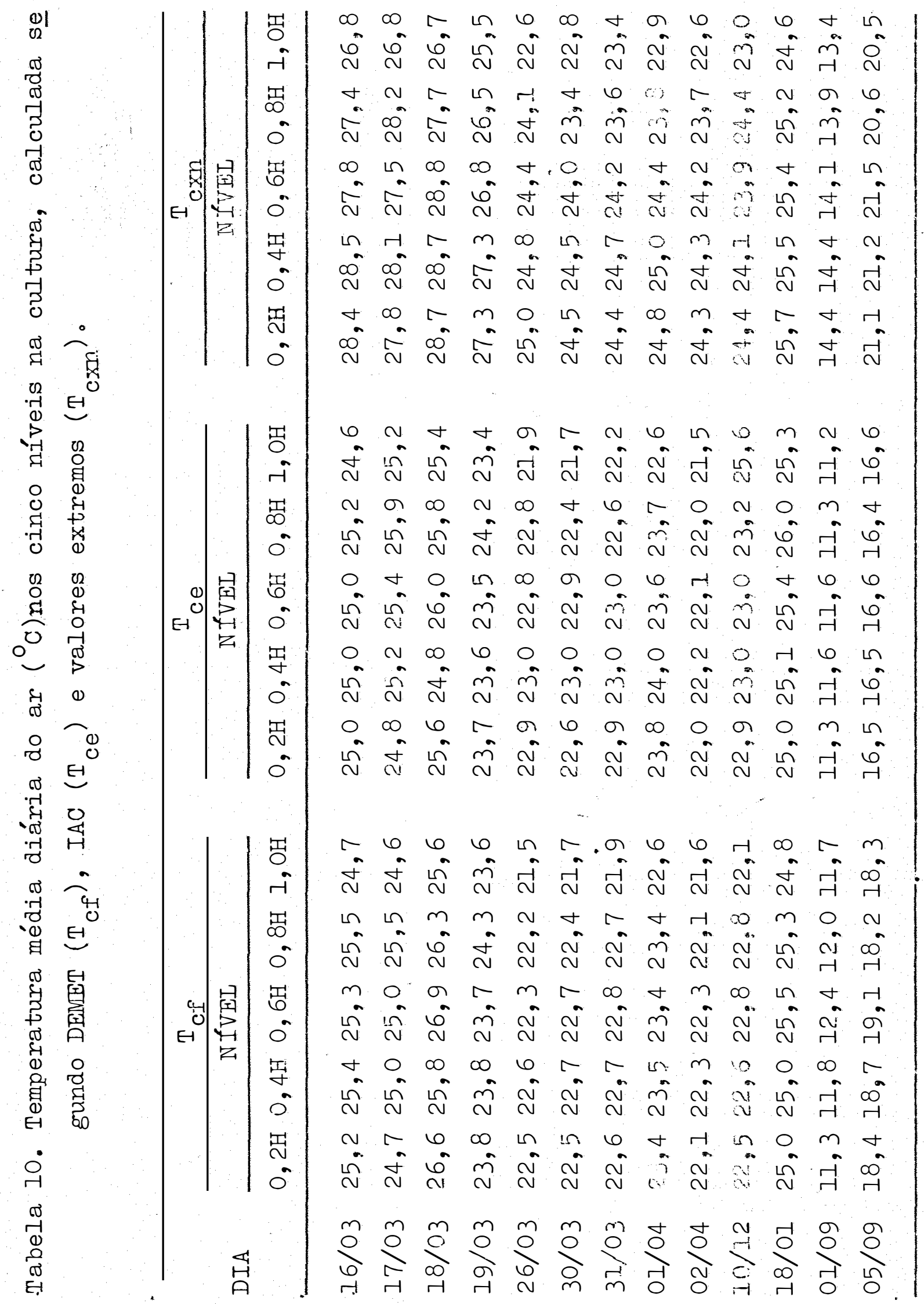


.38.

Tabela 11. Temperatura média diária do ar no posto neteorológi co calculada segundo DEVET $\mathrm{T}_{\mathrm{pf}}$, IAC $\mathrm{T}_{\mathrm{pe}}$ e temperatu ras extremas $\mathrm{T}_{\mathrm{pxn}}$; temperatura máxima $\left(\mathrm{T}_{\mathrm{px}}\right)$ e tempe ratura mínima $\left(\mathrm{T}_{\mathrm{pn}}\right)$, em graus centígrauos.

\begin{tabular}{|c|c|c|c|c|c|}
\hline \multirow[b]{2}{*}{ DIA } & \multicolumn{3}{|c|}{ MÉDIAS } & \multicolumn{2}{|c|}{ EXTREMAS } \\
\hline & ${ }^{T} p f$ & $\mathrm{~T}_{\mathrm{pe}}$ & ${ }^{T} p \times m$ & $T_{p x}$ & $T_{p n}$ \\
\hline $16 / 03$ & 25,6 & 25,4 & 27,4 & 33,0 & 21,8 \\
\hline $17 / 03$ & 25,6 & 25,7 & 27,1 & 33,5 & 20,7 \\
\hline $18 / 03$ & 26,5 & 26,1 & 28,3 & 33,5 & 23,0 \\
\hline $19 / 03$ & 24,8 & 26,0 & 26,3 & 33,0 & 19,5 \\
\hline $26 / 03$ & 22,3 & 22,7 & 23,5 & 28,7 & 18,2 \\
\hline $30 / 03$ & 22,7 & 22,8 & 24,1 & 29,9 & 18,2 \\
\hline $31 / 03$ & 22,6 & 22,5 & 24,1 & 29,4 & 18,7 \\
\hline $01 / 04$ & 22,3 & 22,1 & 24,0 & 29,5 & 18,5 \\
\hline $02 / 04$ & 21,9 & 21,6 & 24,0 & 29,9 & 18,0 \\
\hline $10 / 12$ & 22,7 & 22,8 & 23,4 & 28,0 & 18,7 \\
\hline $18 / 01$ & 24,4 & 24,8 & 25,0 & 30.0 & 20,0 \\
\hline $01 / 09$ & 12,4 & 12,5 & 13,3 & 19,2 & 7,4 \\
\hline $05 / 09$ & 18,0 & 16,2 & 20,1 & 25,0 & 15,2 \\
\hline
\end{tabular}




\section{ANALISE E DISCUSSÃO}

\subsection{Temperatura das Folhas}

6.1.1. Curso Diário da Temperatura das Folhas

o curso diário da "temperatura das folhas e do ar para as diferentes alturas no período de ensaio, no inte rior da cultura, é mostraảo nas Figuras 6,7 e 8 , corresponden do respectivamente aos níveis de $0,2 \mathrm{H}, 0,4 \mathrm{H}$ e $0,6 \mathrm{H}, \quad$ construí das a partir das Tabelas 3 e 4 。 Nessas figuras estão incluídos os valores de vento percorrido, formação de orvalho, nascer e por do sol.

Verificou-se que os cursos da temperatura das folhas variam com o nível no interior da cultura. A temperatu ra das folhas variou entre os limites de $17,7^{\circ} \mathrm{C}$ a $39,7^{\circ} \mathrm{C}$, de $16,2^{\circ} \mathrm{C}$ a $40,3^{\circ} \mathrm{C}$ e $17,6^{\circ} \mathrm{C}$ a $38,0^{\circ} \mathrm{C}$ respectivamente para os ní veis de $0,2 \mathrm{H}, 0,4 \mathrm{H}$ e $0,6 \mathrm{H}$. Estes valores de empertura são in feriores aos citados por KIRKPATRICK (1935), abrangem os obti dos por SANTOS et alii (I958) e são inferiores aos valores má ximos registrados pela Seção de Climatologia Agrícola do Insti 
.40.

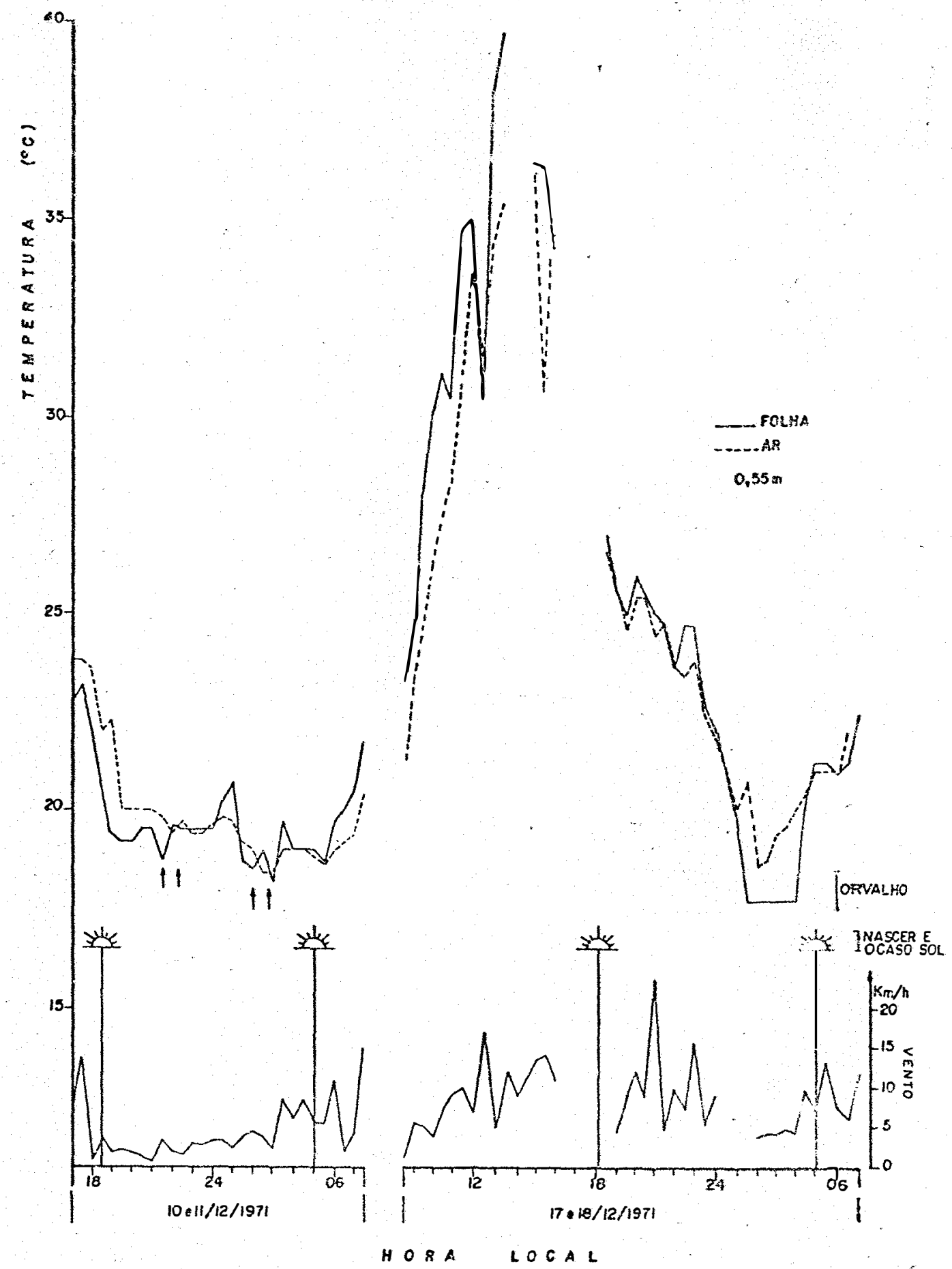

Figura 6. Curso da temperatura da folhas e do ax no nivel de $0,2 \mathrm{H}$ 。 

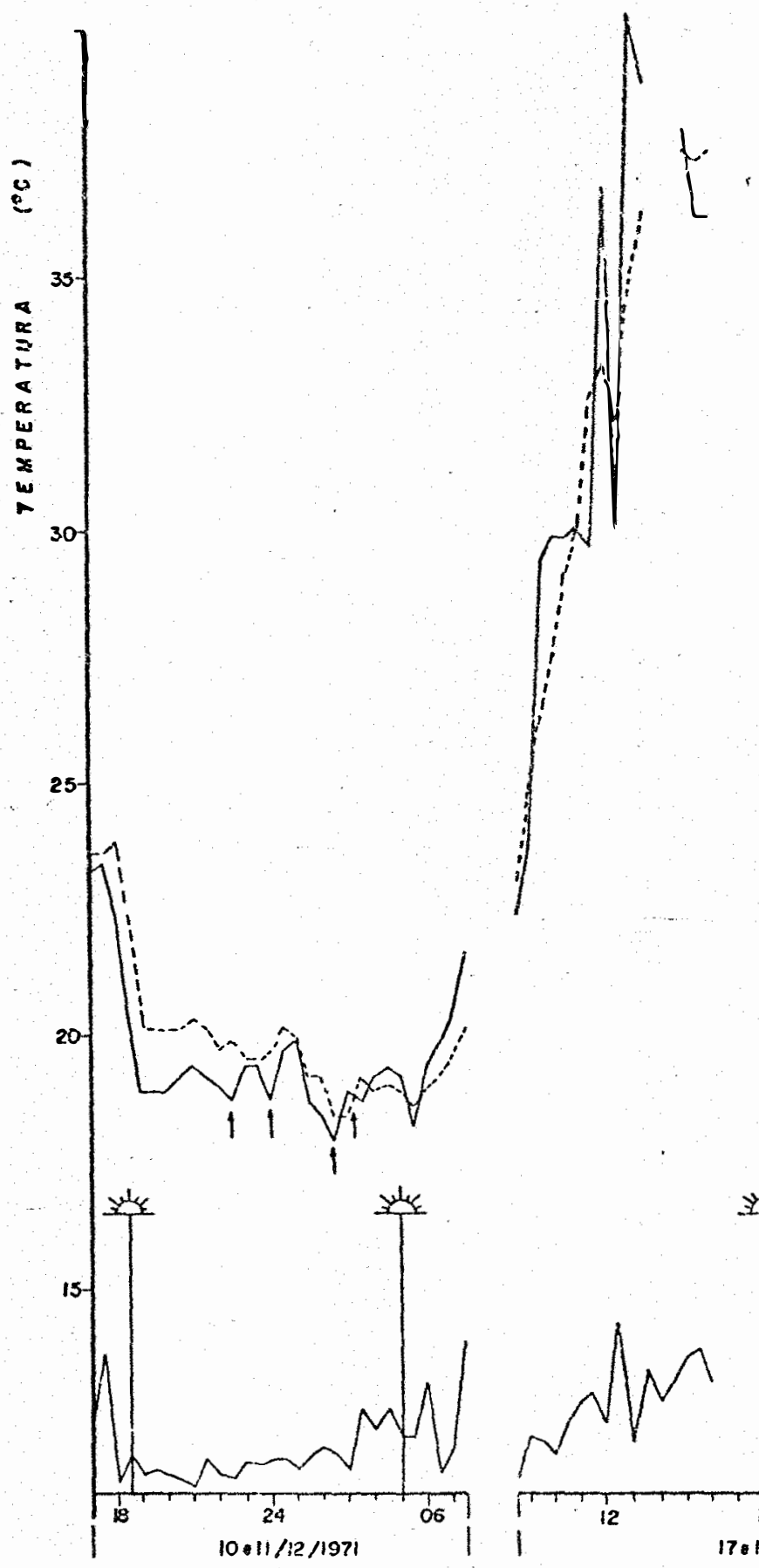

Figura 7. Curso da temoeratura da folha e do ar no nível de $0,4 \mathrm{H}$ 。 


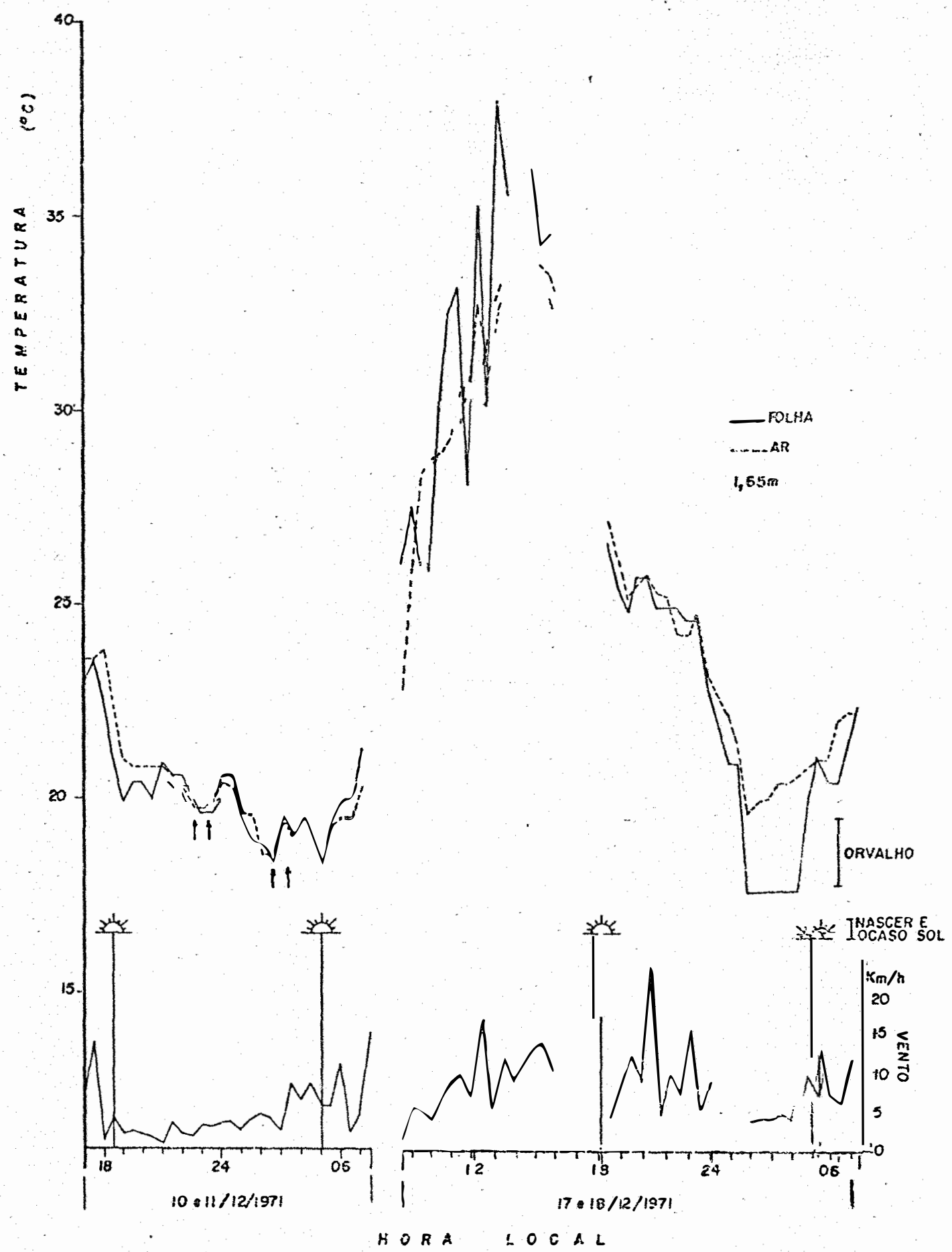

Figura 8. Curso da temperatura da folhas e do ar no nível de $0,6 \mathrm{H}$ 。 
tuto Agronômico de Campinas̃, citados por ORTOIANI "(1973)。 Tais valores discordam da afirmativa de PRIESTLEY (1960), que admi te o valor de $33^{\circ} \mathrm{C}$ como temperatura limite superior de plan tas, uma vez que o balanço hídrico mọtrava boa disponibilida de de água no solo, no períocio de ensaio, não se justificando a ocorrência de uma deficiếncia hídrica. Segundo ANSARI e LOO MIS (1959) estes valores são possíveis de ocorrer, uma vez que folhas murchas ou túrgidas apresentam um comportamento seme lhante de variação de temperatura.

De maneira geral, a temperatura das folhas, du rante o período noturno, foi meror que a do ar, confirmando constatações de SHAW (1954) e de SANTOS et alii (1958)。 Entre tanto ocorreram momentos nos quais a temperatura ás folhas se tormava maior ou igual a temperatura do ar, como consequência da formaçã de orvalho ou da cobertura do céu. Quardo da forma ção de orvalho, ocorre liberação de calor Iatente, que provoca um incremento da tempèratura das folhas, tomando-a maior que a temperatura do ar. Este fato pode ser observado no período de 10 a 11 , nas Figuras 6, 7 e 8, onde os momentos de início de quatro formações consecutivas estão indicados através àas setas. Estas alterações de temperatura, provocadas pela libera ção do calor de condensação, foram verificadas arteriormente por NASCIMENTO (1973) em cultura de café. Embora na noite de 17 a 18 não tenha ocorrido orvalho, a temperatura das folhas, no período das 18 às 24 horas, Figuras 6, 7 e 8, suplantou a temperatura do ar. Isto se deve a ocorrência de densa nebulosi dade, fato também observado por NOFFSIVGER (196I).

A temperatura das folhas no período diurno per maneceu acima da do ar. Isto se deve ao fato da folha ser o 
elemento receptor de energia solar. Verifica-se, nas Figuras 6,7 e 8, a ocormência de momento nos quai a temperatura da folha torna-se mencr que a do ar, devido a interceptação da ra diação direta pela passasem de nuvens', também constatados por KIRKPATRICK (I935); SANTOS et alii (1958), ANSARI e IOONIS (1959) e GATES (1962). É provável que a temperatura da folha permaneça acima da do ar enquanto o balanço de radiação for po s.itivo, fato que normalmente se manifesta desde após o nascer até antes do ocaso do sol.

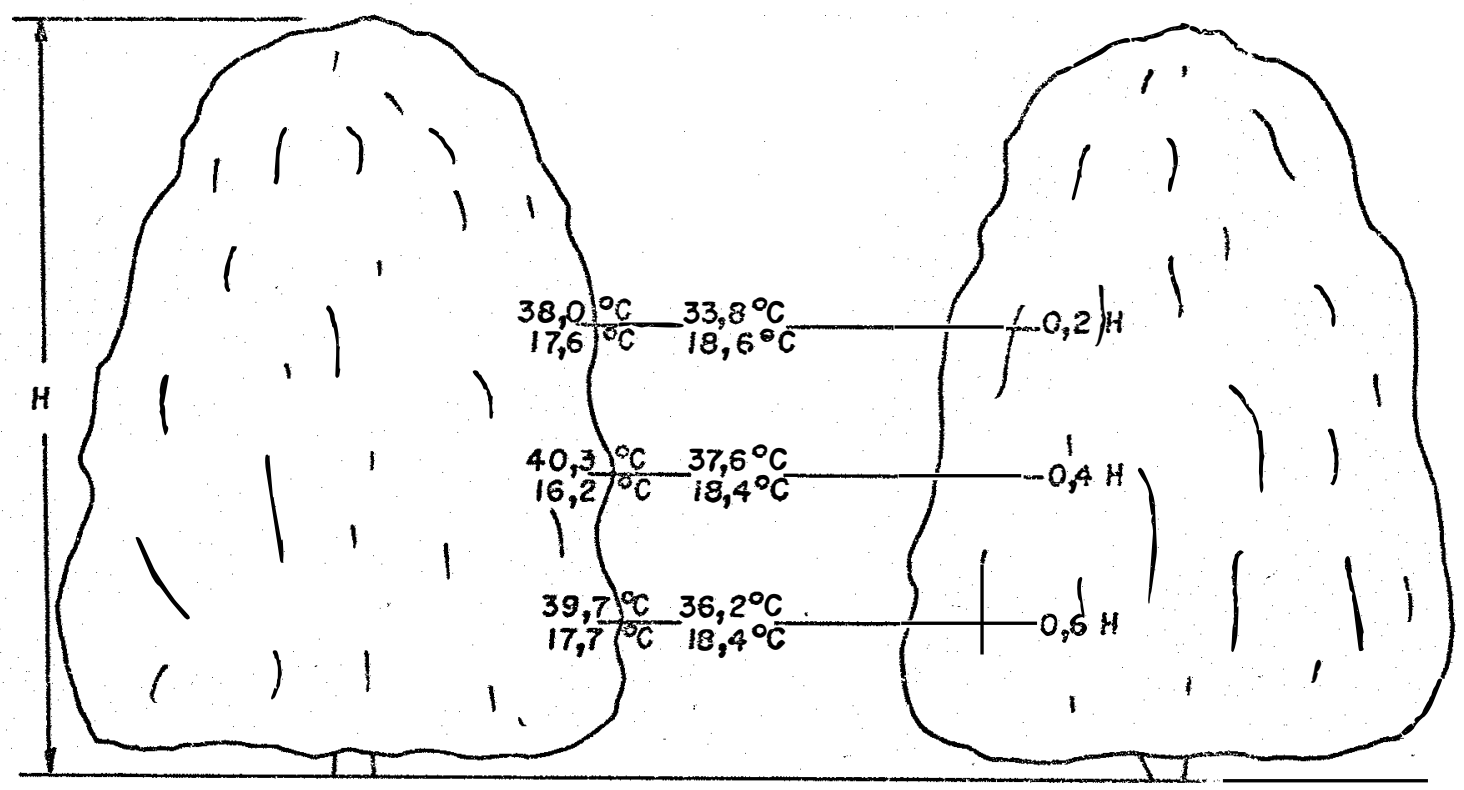

Figura 9. Temperaturas extremas da folha e do ar nos três ní veis na cultura.

Comparando-se as temperaturas extremas no inte rior da cultura, verificou-se a seguinte ordein de srandeza: de crescente para as máximas, $0,4 \mathrm{H}, 0,2 \mathrm{H}$ e $0,6 \mathrm{H}$ tanto para a fo Iha como para o ar; crescente para as mínimas, $0,4 \mathrm{H}, 0,6 \mathrm{H}$ e 
$0,2 \mathrm{H}$ para as folnas e $0,2 \mathrm{H}, 0,4 \mathrm{H}$ e $0,6 \mathrm{H}$ para 0 ar, conforme é mostrado na Figura 9.

\subsubsection{Desvios da Temperatura des Tolhas em Relacão Temperatura do Ar}

Com os dados das Tabelas 3 e 4, calculou-se os desvios da temperatura das folhas em relaçã ż do ar, para os três níveis de observação, àos dois períodos de ensaio. Estes resultados estão pontuados na Figura 10 .

De uma forma geral., os desvios comportaram-se de forma semelhante nos três níveis. A tendência àos desvios é de serem positivos durante o período diurno e negativos du. rante o noturno, o que concorda com as observações de SANTos et alii (1958). No período noturno, os desvios negativos são maiores em condições de céu descoberto, como aconteceu no in. tervalo das zero às 04 hoo do segundo período. Desvios menores foram cbservados sob condições de nebulosidade e àe formą̧̃o de orvalho, respectivamente, como os observados entre as $19 h 00$ e $24 h 00$ do segundo período e entre 2 Ih 30 às 05 h0o do primeiro período, ocorrendo inclusive valores positivos de desvios, con firmando os trabalhos de SHAW (1954), NOFFSINGER (196I) e NAS CIMENTO (1973).

No período diumo, a tendência dos desvios é acompanhar o curso díário da rađiação solar Ẻobai Estes des vios são alterados pela passagem de nuvens, podendo inclusive ocorrer inversão nos sinais, como pode ser observado no segun 


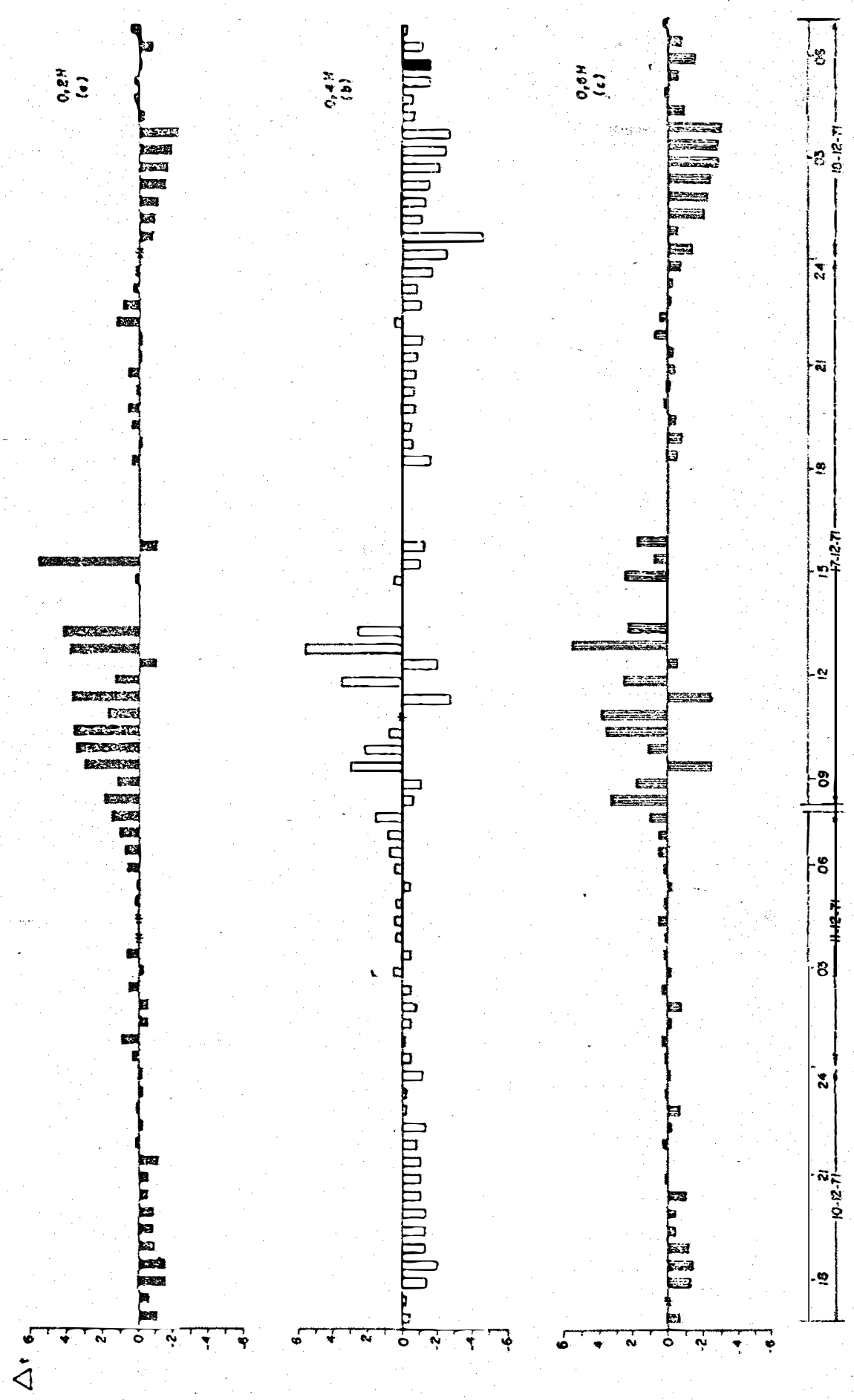

(1)

(1)

चै द्ञ

강

41

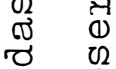

เง 0

点

\&્丩 02

ब्व

เి 2

(1) म्न

tै

(1)

ช2 बु

$p \quad$

व) ठ্

U 0 O

क्ष

\&

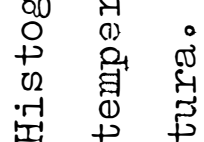

त्

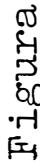


do período das $08 h 30$ até as 16h00, concordando con àAiS(1962) para outras culturas e KIRKPATRICK (1.935) er caferal.

Os vaiores extremos dos desvios para os perio dos notumo e diumo, nos diferentes níveis e pertodos de en saio, estão contias na Tabela 12. O náximo desvio positivo no turmo foi de $+1,0^{\circ} \mathrm{C}$ no nível de $0,2 \mathrm{H}$, no primeiro período, à olh0o quando a temperatura do ar era $19,7^{\circ} \mathrm{C}$. o maior valor ne gativo para o período noturno foi de $-4,8^{\circ} \mathrm{C}$ e ocomeu no nível de $0,4 \mathrm{H}$, no segundo período à $01 \mathrm{hOO}$, quando a temperatura do ar era de $21,0^{\circ} \mathrm{C}$, o máximo àesvio positivo diumo foi de $+5,7^{\circ} \mathrm{C}$ e ocorreu no nível de $0,2 \mathrm{H}$, no segundo pertodo às $15 \mathrm{~h} 30$, quan do a temperatura do ar era de $30,6^{\circ} \mathrm{C}$. 0 máximo vaior negativo foi de $-2,9^{\circ} \mathrm{C}$ e ocorreu no nível de $0,4 \mathrm{H}$, no segurido período às 11 h30, quando a temperatura do ar era de $32,6^{\circ} \mathrm{C}$. Estes des vios concordam com os valores constatados por ANSARI e IOOMIS (1959) para outras culturas e com KIRKPATRICK (1935) e SAITOS et alii (1958) para a cultura de café.

6.1.3. Relações entre a remperatura das Folinàs e do Ar

Os valores de temperatura das folhas e do ar, contidos nas tabelas 3 e 4, foram relacionados Iivarmente. Na tabela 13 encontram-se os valores do coeficiente linear, angu lar è de correlação, teste $t$ e significância de " e desvio padrão da regressão, para aquelas equações para os três níveis。 
.48 .

Tabela 12. Temperatura do ar nos momertos em que a temperatura da folha $\left(\mathrm{T}_{f}\right)$ e a do ar $\left(\mathrm{T}_{\text {ar }}\right)$ fo... extrema.

\begin{tabular}{|c|c|c|c|c|c|c|c|}
\hline \multirow[b]{2}{*}{$\begin{array}{l}\text { NIVEL } \\
(\mathrm{H})\end{array}$} & \multirow[b]{2}{*}{ PERIODO } & \multicolumn{3}{|c|}{ NOTURNO } & \multicolumn{3}{|c|}{ DIURNO } \\
\hline & & HORA & $\begin{array}{l}{ }^{\mathrm{T}} \text { ar } \\
{ }^{\circ} \mathrm{C}\end{array}$ & $\begin{array}{c}\mathrm{T}_{f}-\mathrm{T}_{\mathrm{ar}} \\
\mathrm{O}_{\mathrm{C}}\end{array}$ & HORA & $\begin{array}{l}T_{e r} \\
{ }_{0}\end{array}$ & $\begin{array}{c}\mathrm{T}_{f}-\mathrm{T}^{\mathrm{T}} \text { ar } \\
{ }^{\mathrm{O}_{\mathrm{C}}}\end{array}$ \\
\hline \multirow{4}{*}{$\mathrm{O}, 2 \mathrm{H}$} & \multirow{2}{*}{10} & Olhoo & 19,7 & $+1,0$ & - & - & - \\
\hline & & $2 \ln 30$ & 19,8 & $-1,0$ & $08 \mathrm{ho0}$ & 23,6 & $-1,6$ \\
\hline & \multirow{2}{*}{20} & $22 \mathrm{~h} 30$ & 23,4 & $+1,3$ & $15 \mathrm{~h} 30$ & 30,6 & $+5,7$ \\
\hline & & $04 \mathrm{hOO}$ & 20,0 & $-2,3$ & $16 \mathrm{~h} 00$ & 35,2 & $-1,0$ \\
\hline \multirow{4}{*}{$0,4 \mathrm{H}$} & \multirow{2}{*}{10} & $03 \mathrm{hOO}$ & 18,4 & $+0,5$ & - & - & - \\
\hline & & $19 \mathrm{~h} 30$ & 20,2 & $-1,3$ & $18 \mathrm{~h} 30$ & 22,2 & $-2,0$ \\
\hline & \multirow{2}{*}{20} & $22 \mathrm{~h} 30$ & 23,2 & $+0,4$ & $13 \mathrm{~h} 00$ & 34,8 & $+5,5$ \\
\hline & & Olhoo & 21,0 & $-4,8$ & $\operatorname{lnh} 30$ & 32,6 & $-2,9$ \\
\hline \multirow{4}{*}{$0,6 \mathrm{H}$} & \multirow{2}{*}{10} & $04 h 30$ & 19,0 & $+0,5$ & - & - & - \\
\hline & & $19 \mathrm{~h} 00$ & 21,0 & $-1,1$ & $18 \mathrm{~h} 30$ & 22,4 & $-1,3$ \\
\hline & \multirow{2}{*}{20} & $22 \mathrm{~h} 00$ & 24,2 & $+0,7$ & $13 \mathrm{hOO}$ & 32,6 & $\div 5,4$ \\
\hline & & $04 h 00$ & 20,6 & $-3,0$ & $\operatorname{lnh} 30$ & 30,6 & $-2,5$ \\
\hline
\end{tabular}


Tabela 13. Coeficiente linear (a), angular (b) e de correlação $(r)$, teste $t$ e significância de "." e desvio pa drão da regressão para as regressões lineares entre a temperatura da folha e dó ar nos três ríveis de medição。

INIVEL

$$
\mathbf{T}_{f}=a+b \cdot \mathbf{T}_{a r}
$$

\begin{tabular}{lllllll}
$n$ & $a$ & $b$ & $r$ & $t(r)$ & $\begin{array}{llll}\text { Sig } \\
\text { "r" }\end{array}$ & Sy $x$ \\
\hline
\end{tabular}

$\begin{array}{crrrrrrr}0,2 \mathrm{H} & 70 & -3,5 & 1,17 & 0,97 & 33,7 & 1 \% & 1,33 \\ 0,4 \mathrm{H} & 70 & -2,6 & 1,09 & 0,97 & 32,3 & 1 \% & 1,44 \\ 0,6 \mathrm{H} & 70 & -4,0 & 1,17 & 0,97 & 30,7 & 1 \% & 1,37 \\ 0,2 \text { a } 0,6 \mathrm{H} & 210 & -3,2 & 1,13 & 0,97 & & 1 \% & 1,44\end{array}$

Existe correlação estatisticamente significante

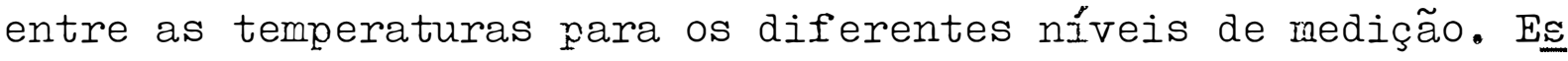
tes resultados concordam com IINACRE (1964), que mostrou a $\underline{e}$ xistência de relação linear entre estes parâmetros para diver sas cülturas. Os valores de "r" são iguais para ow três ní veis, mostrando que a temperatura da folha é igualmente cor relacionada com a temperatura do ar na curtu "a.

A representação gráfica da temperatura dás fo Thas e do ar, e das equações lineares de regressão entre estes dois parâmetros está mostrado na figura ll. As equações encon 
.50.

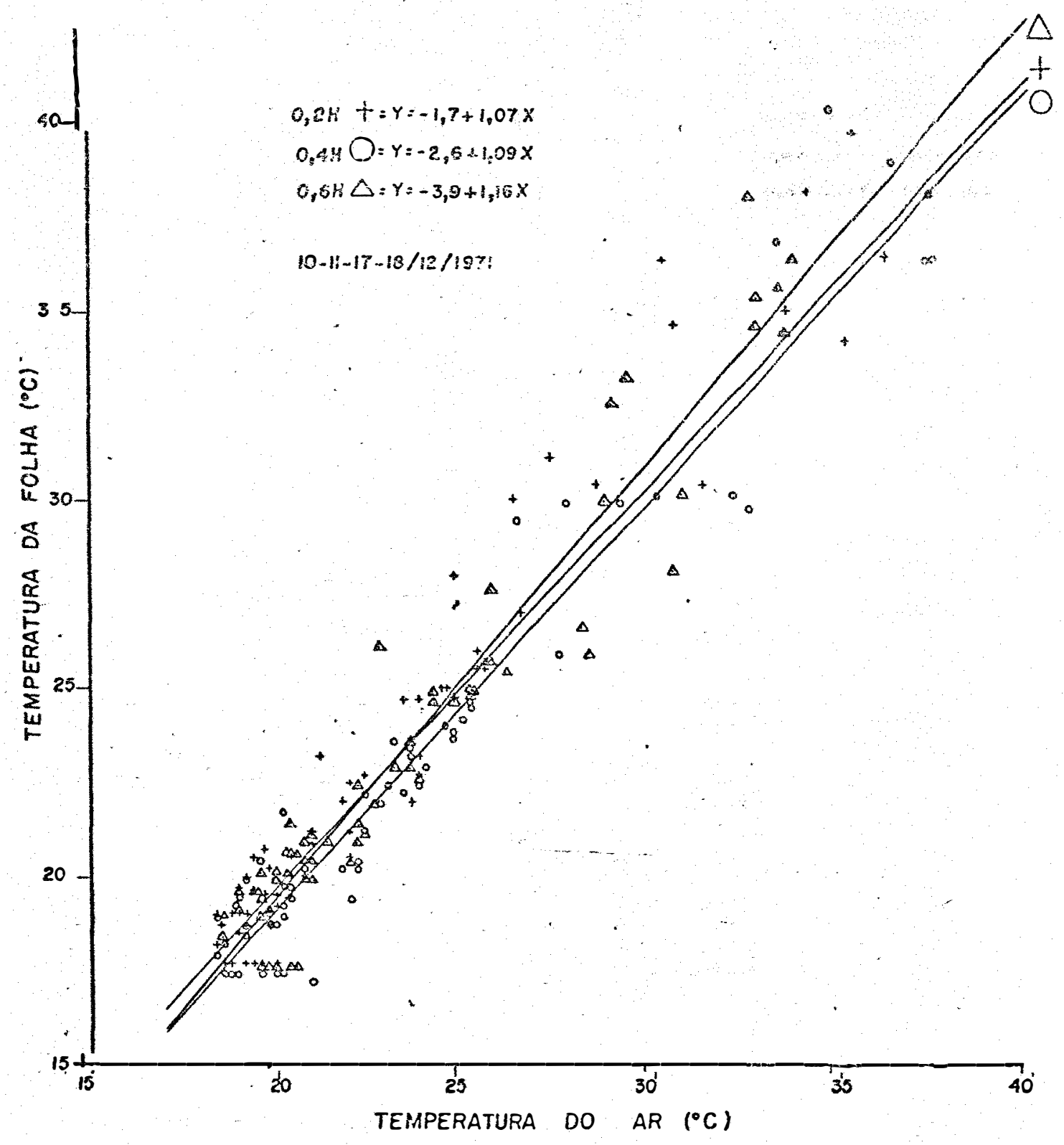

Figura 11. Diagrama de dispersão da temperatura das folhas e do ar e equações lineares de réc eessão nos três níveis da cultura. 
tradas interceptam a reta $y=x$. Acima da intersevg̃o, a tempe ratura das folhas ó maior que a do ar, e ab ixo dela ocorre o inverso. Seguncio IINACRE (1964) era de se esperar que a tempe ratura da folna fosse menor que a temperatura do ar acima do ponto de interseccão. Os dados obtidos revelom entretanto que acima deste ponto as temperaturas das folhas suplartaram as temperaturas do ar contrariando aqueleautor. Os dados obtidos neste trabalho encontram fundamento no fato de que as superfí cies receptoras de energia, folhas e solo, governant a temperatura do ar, aquecendo-se ou esfriando-se, e não o inverso.

o ponto de interseç̧ão deveria ocorrer a $33^{\circ} \mathrm{C}$ segundo IINACRE (1964). Entretanto ocorreu nas temperaturas de $23,8^{\circ} \mathrm{C}, 29,8^{\circ} \mathrm{C}$ e $23,6^{\circ} \mathrm{C}$, respectivamente para os níveis de. $0,2 \mathrm{H}, 0,4 \mathrm{H}$ e $0,6 \mathrm{H}$, mostrando qưe não apresenta um valor fixo pré-determinado, sendo função da temperetura média do ar e da temperatura média da folha, que variars conforme o rível no in terior da cultura.

6.1.4. Relações entre as Diferenças da Temceratura das Folhas e do Ar e Vento Percorrido

Com os valores dos desvios da temperatura das folhas em relação a temperatura do ar, calculados a partir das tabelas 3 e 4 e com os dados do vento percomido da tabela 5, pontuou-se a figura 12 .

Verificou-se que os destios, positivos e negati vos, não mostrarara relação com o vento percorrido. Isto mostra que a velocidade do vento não é fator predominanto no estabele 
.52.

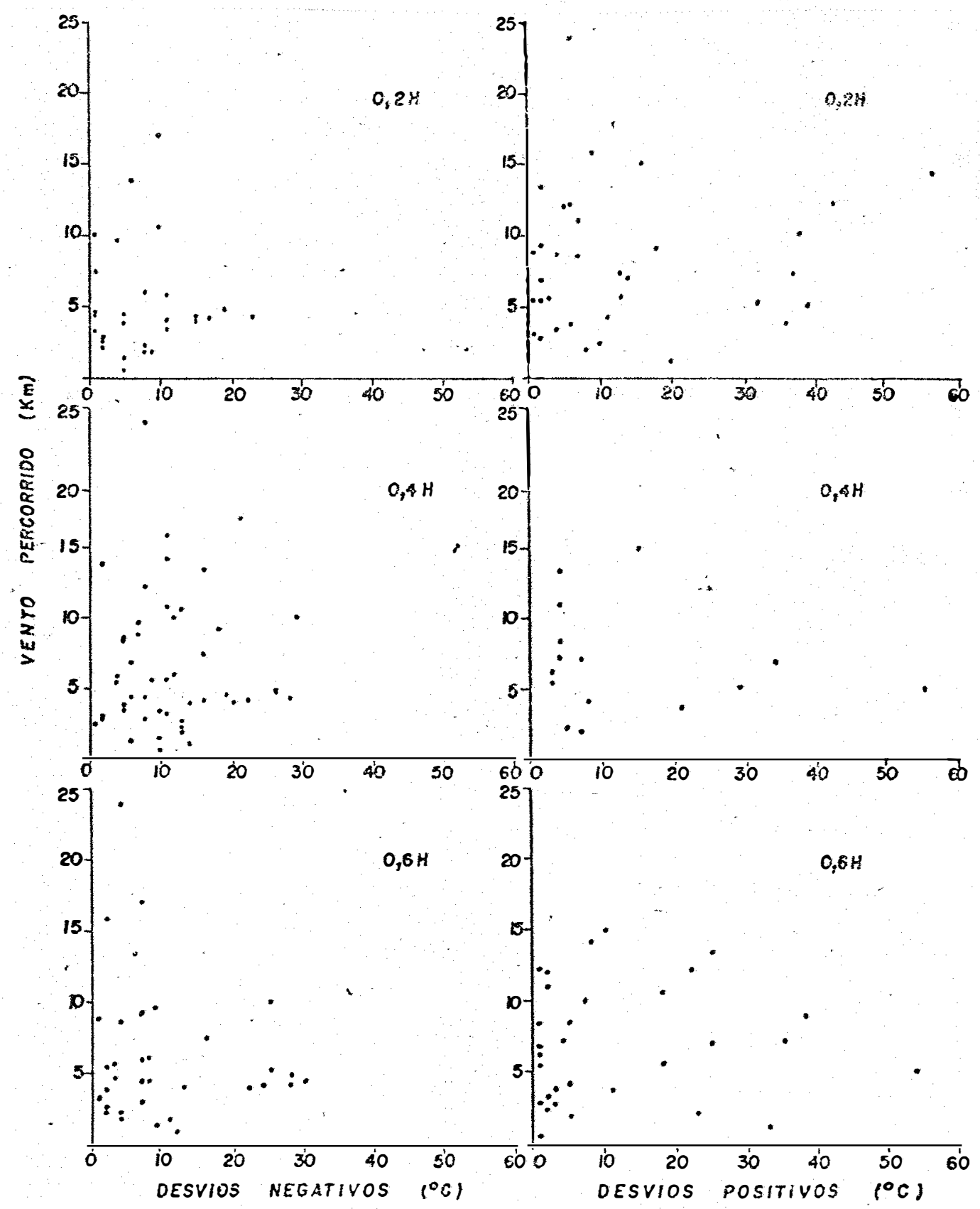

Figura 12. Diagrama de distribuição dos destios entre a temperatura das folhas e do ar em funçăo do vento percorrido。 
cimento dos desvios, sendo secundária sua imnortầ ta. Segundo GAIES (1965), SANIOS et alii (1958) e PRIESTim (1966) o fator deterninante àos desvios é o balanço ae radiação, a que também pode ser inferido na figura 1.1.

6.2. Temperatura do Ar no Cafezal

6.2.1. Curso Diário da Temperatura do Ar

o curso diário dos valores méaios horários da temperatura do ar no cafezal, mostrado na figura 13, foi cons truído com os dados da tabeia 7 .

A temperatura do ar no cafezal nä̃ sombreado tem um curso diário semelhante ao curso diário obtido nos pos tos meteorológicos. Este comportamențo também foi constatadó por KIRKPATRICK (1935), COSTA e SCHRÖDER (1956) para, café e MATTSSON (1961) para beterraba açucareira. A temperatura mini ma ocorre entre 05 e 06 horas e a máxima entre 14 e 15 horas.

No período notumo, os maiores valoies de tempe ratura do ar ocorrem de 0,6 a $0,8 \mathrm{H}$, decrescendo em direção ão solo e ao topo das plantas. Durante o dia a região mais quen te situa-se em tomo de $0,4 \mathrm{H}$, decrescendo pouco em iireção ao solo e mais intensamente em direção ao topo das plairtas.

o cruzamento do curso da temper tura nos dife rentes níveis se dá no período da manhã entre 08 e 10 horas, e no período da tarde entre 16 e 18 horas. Resultados semelhan tes foram obtidos por COSTA e SCHRÖDER (1965) em cultura de ca fé, quarido comparou as temperaturas ae 0,2 m e 4,06 mo Estes 


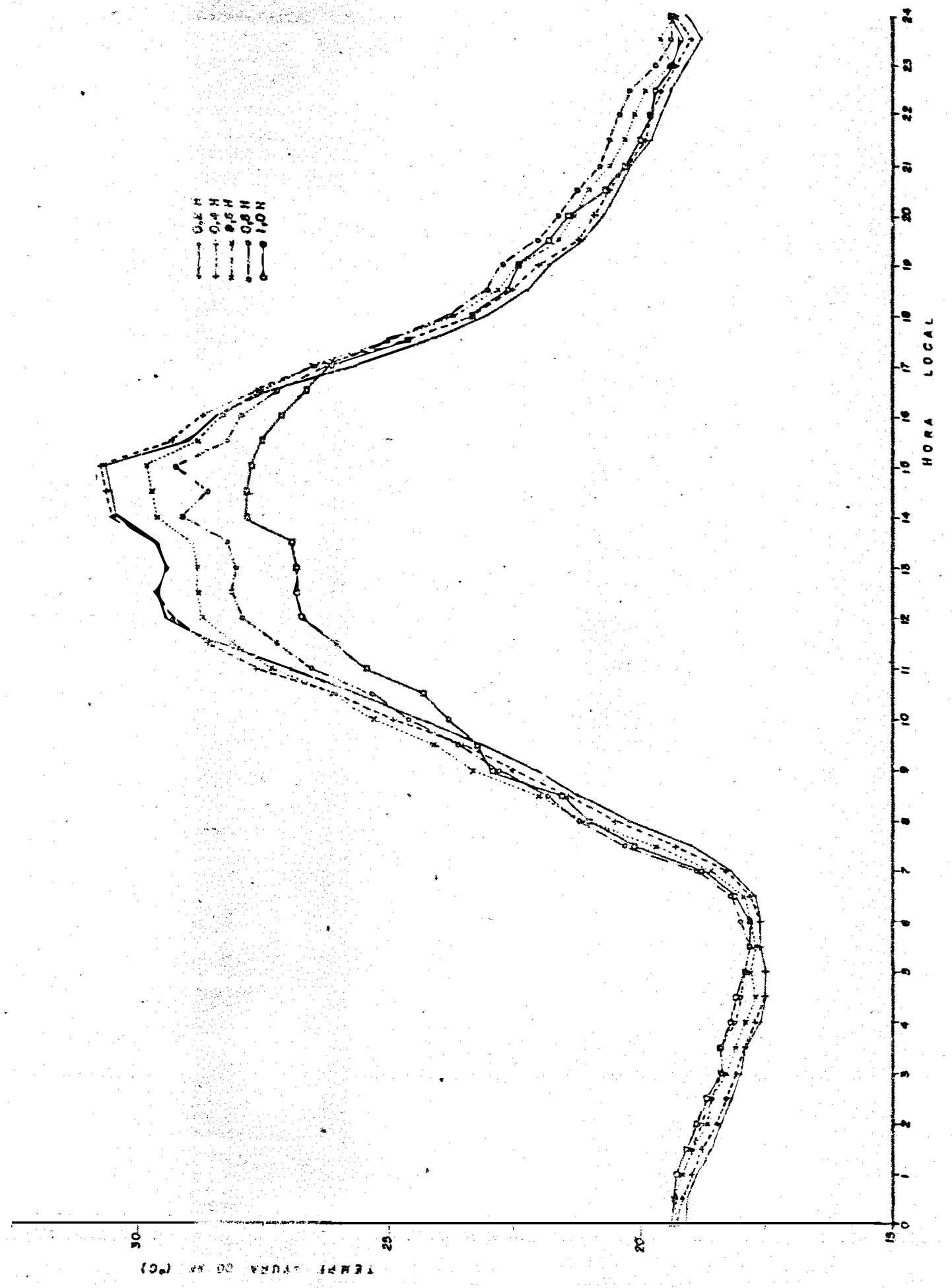

요

ฮี

잉

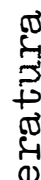

密

$+$

శึ

02

$20^{\circ}$

o 0

.

ब

ज व

थ 20

离

离

o2 0

○.

엉

त्-

○

\%

ปี

変

กำ

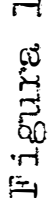


autores mostram os cruzamentos às 10 e 14 horas pare um perío do chuvoso, e 10 e 16 horas para um período eco. Os interva los de ocorrência das interseçöes dos cursos de temperatura nos diferentes niveis englobam os dois momentos determinados por COSTA e SCHRODER (1956), pois estes autores só vrabalhararn com dois níveis.

Durante o período notumo, a temperatura no ní vel $0,2 \mathrm{H}$ é menor e durante o período diumo é maior que o njé vel de I,OH. No período noturno, a diferença témices entre os níveis é pequena e relativamente constante, enquanto que em torno do meio do dia a diferença é grande, e apresenta maior variação.

6.2.2. Sequência Espacial da Temperatura do Ar

A sequência espacial da temperatura média horá ria do ar no cafezal, elaborada a partir dos dados contidos na tabela 7, é apresentada na Iigura 14. Esta seqû̃encia se as semelha à mostrada por GEIGER (1965) para alcachofra em um dia de verão e por MATTSSON (1961) para a cultura de trigo na pri mavera。

A figura 14 mostra o caminhamento das isotermas no decorrer do dia no interior da cultura, bem como os momen tos de ocorrência das temperaturas extremas. Ocorre um rápido incremento de temperatura entre às 07 e às 1.. hores, atingindo uma variação de praticamente $10^{\circ} \mathrm{C}$. Neste período as isotermas deslocam-se aproximadamente em paralelo, evidenciando um aque cimento semelhante em todos os níveis. No período entre às $I I$ 


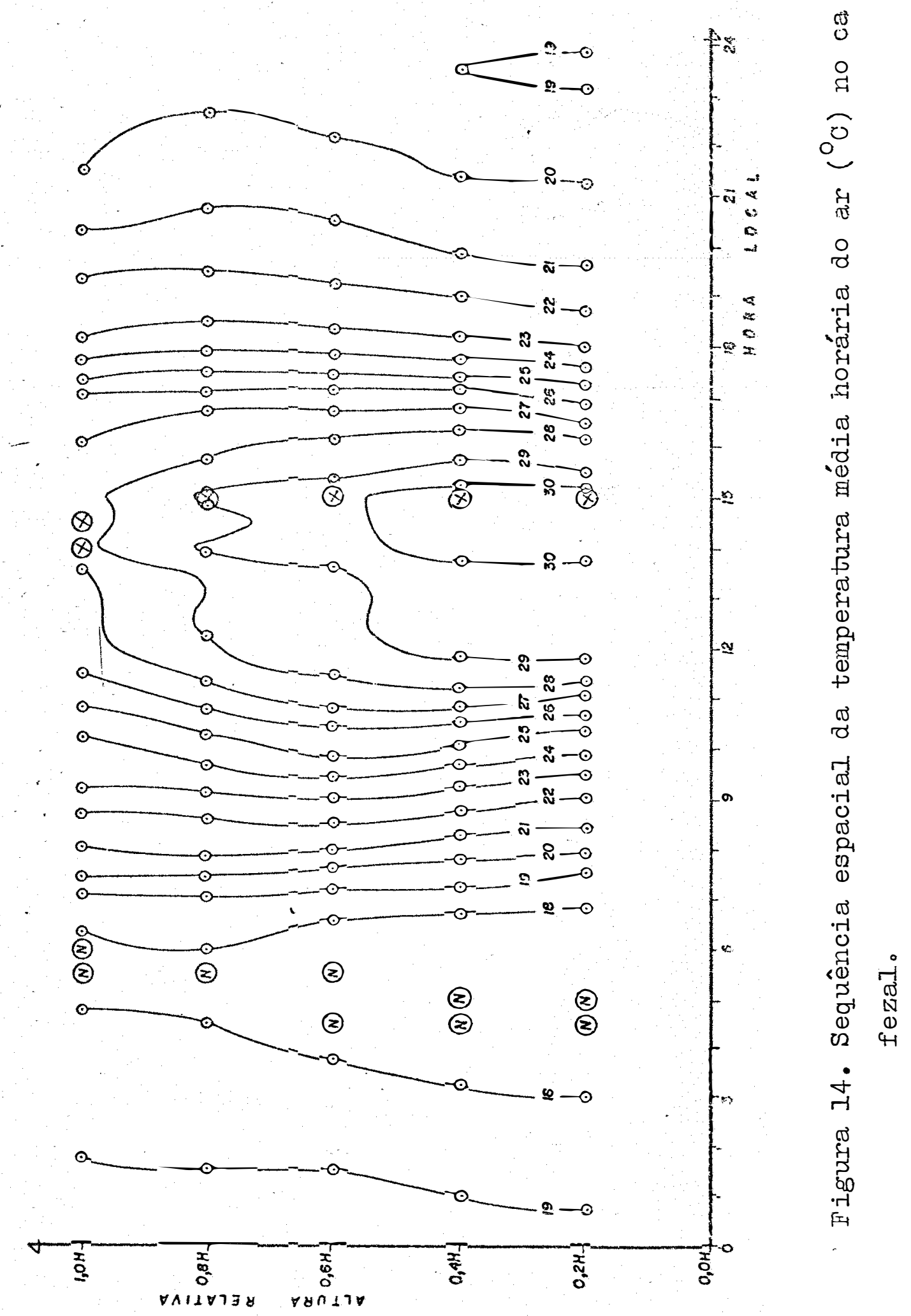


e às 16 horas ocorre uma pequena variação ảe temperatura, de aproximaảamente $3^{\circ} \mathrm{C}$. As isolinhas tendem a frrma elipsóides no interior da cuitura, com os maiores valores juxto aos ní veis de 0,2 e 0,4its evidenciando que nestes nívejs ocorrem os maiores ganhos de energia, condicionando a região de maior a quecimento。

A localização da região de maior aquecimento a parentemente difere da encontrada por KIRIPATRICK (1935)。Este autor constatou que, durante o dia, a temperatura do ar no to po das plantas de café foi em média $2^{\circ} \mathrm{C}$ major que a $1,30 \mathrm{~m}$ no interior da cultura. A discordância se deve ao fato do cafezal por ele estudado ser plantaco no espaçamento $2,4 \mathrm{x} 2,4 \mathrm{~m}$, que condiciona uma cultura fechada, de modo que o nível de maior recepção de energia localizar-se-á mais alto que no presente trabalho。

A partir das 16 horas, a temperatura sofre um rápido decréscimo até as 18 horas, ocorrendo uma variação de aproximadamente $5^{\circ} \mathrm{C}$. Neste período as isoternas deslocam-se a proximadamente em paralelo, evidenciando um resfrianento seme Thante em todos os níveis. Das 18 às 07 horas ocorre uma peque na e lenta variação de temperatura, da ordem de 4 C. Entre 23 e 24 horas as isotermas dão origem a um elipsóide, evidencian do que as menores temperaturas estão entre 0,2 e 0,4H, mostran do que esta região é a de maior perda de energia.

6.2.3. Sequência Diária dos Tautócro os Méios horá rios

A sequência diária dos tautócronos médios horá 
rios construída a partir da tabela 7, é apresentada na figu ra 15.

A sequência obtida assemelha-se as mostradas por MATTSSON (1961) e CHANG (1971) pera solo nu, cEIGER (1965) para solo nu, cana de açucar e aveia e COSrA e SGilÖDER (1956) para café.

A figura 15 mostra que as menores temperaturas ocorreram entre 04 e 06 horas e as maiores entre 14 e 15 ho ras, nos cinco níveis. No período mais frio do dia ocorre o perfil inverso de temperatura. A partir deste período, a tempe ratura do ar aumerita igualmente em todos os níveis até às 07 horas, porém persistindo a inversão. Entre às 07 e 08 horas, a medida que os raios solares vão penetrando no interior da cul tura, nota-se um maior aquecimento nos níveis de $0,6 \mathrm{H}$ e $0,8 \mathrm{H}$, causando un perfil inverso entre $0,2 \mathrm{H}$ e $0,6 \mathrm{H}$ e um perfil nor mal acima deste nível. Das 08 às 09 horas, ocorre um aquecimen to em todos os níveis, sendo entretanto mais pronunciado no ní vel de $0,6 \mathrm{H}$, e mantendo a mesma conformação do tautócrono da hora anterior. Entre 09 e 10 horas, a temperatura no nível de $0,2 \mathrm{H}$ torna-se maior que a $1, \mathrm{OH}$, persistindo um perfil inverso abaixo de 0,6H. Em torno das 11 horas, a região de maior aque cimento passa para $0,4 \mathrm{H}$, e o perfil continua inverso abaixo deste nível.

Após as 11 horas, a região de maion aquecimento desloca-se em direção ao solo, em função da incidẹncia direta dos raios solares sobre a superfície do solo. eliminando a ca mada de inversão, continuando esta condição até as 13 horas, quando ocorre isotermia entre os níveis de 0,2 e 0,4H. Embora a massa de ar no interior da cultura continue a sofrer um aque 
.59.

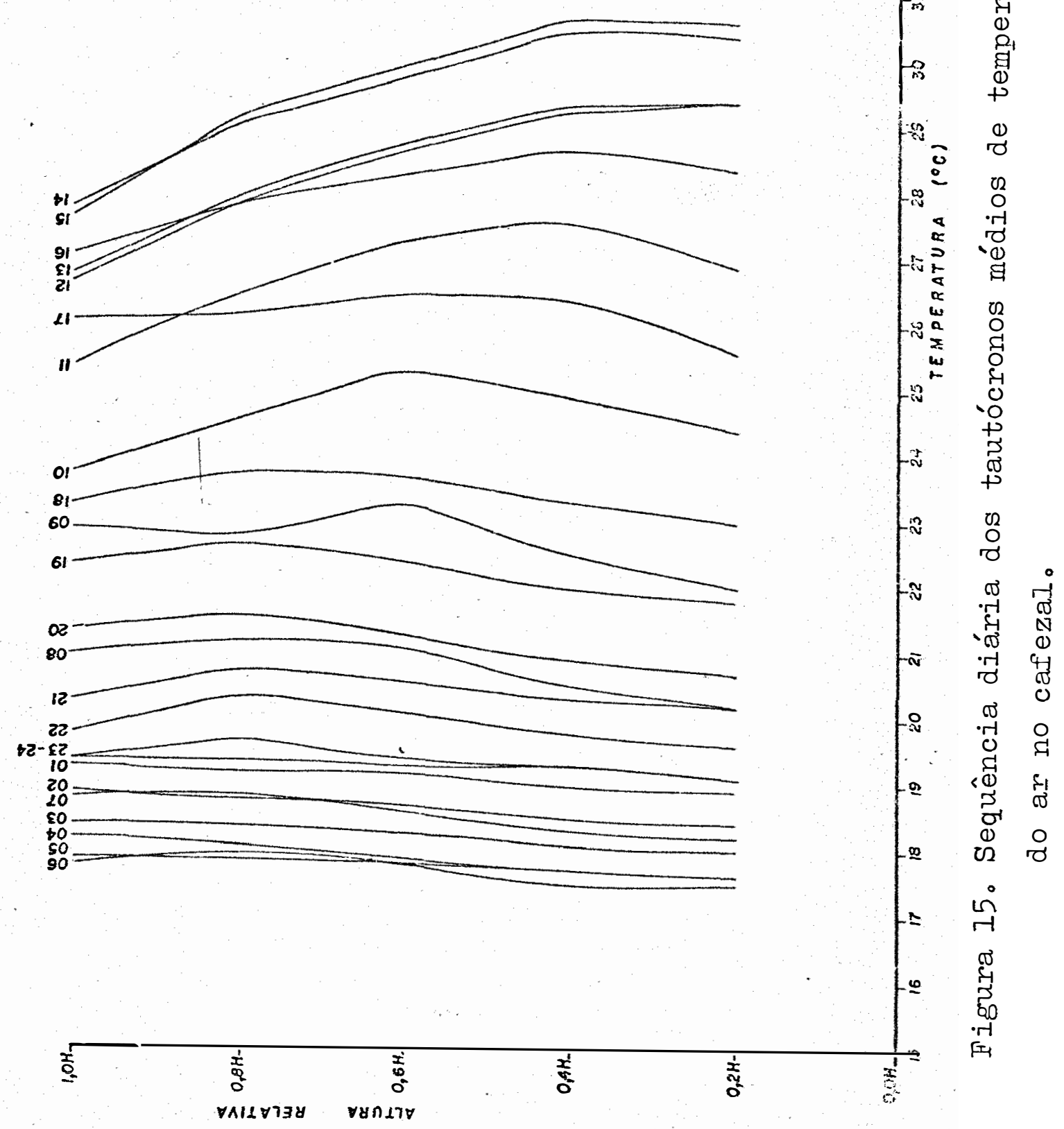


cimento, tem início o aparecimento de uma leve inversão de tem peratura entre os níveis de $0,2 \mathrm{H}$ e 0,4H. Dey dis das 15 horas, a massa de ar se resfria em todos os nívejs, porém mais acentu adamente nos níveis mais próximos ao solo devioo ao fato ds que os raios sojares näo mais incidem diretamente ro mesmo, Co mo consequência, a camada de inversão vai se pronunciando até às 16 horas no nível de $0,4 \mathrm{H}$, até às 17 horas no nível de $0,6 \mathrm{H}$, às 18 horas no nível de 0,8H. Entre 16 e 17 horas a tem peratura no nível de $0,2 \mathrm{H}$, toma-se menor que a $1,0 \mathrm{H}$.

A partir das 18 horas o ar se resfria como um todo, mantendo entretanto a forma do perfil, majs quente no ní vel de $0,8 \mathrm{H}$. Esta situação persiste até às 24 horas, com uma pequena taxa de queda de temperatura. Após às 24 horas, embora o ar continue se resfriando, existe uma pequena variação de temperatura entre os diferentes níveis, predominando um tênue perfil inverso, com a tendência dos maiores valores ocorrerem no nível de $1,0 H$.

A maior amplitude média ocorreu no nível de $0,4 \mathrm{H}$, com um valor de $13,2^{\circ} \mathrm{C}$, decrescendo para $13,1{ }^{\circ} \mathrm{C}$ no nível de $0,2 \mathrm{H}$ e $12,1^{\circ} \mathrm{C}, 11,4^{\circ} \mathrm{C}$ e $9,9^{\circ} \mathrm{C}$, respectivamente para $0,6 \mathrm{H}$, $0,8 \mathrm{H}$ e $\mathrm{I}, \mathrm{OH}$.

6.2.4. Perfis Verticais de Temperatura Miédia Diária

A figura 16 representa os per is verticais mé dios diários da temperatura do ar no cafezal, construídos atra vés dos valores da tabela 8. Para traçar estes perfis, adotouse o nível 1,OH como referência e calculou-se os äesvios dos 
.61.

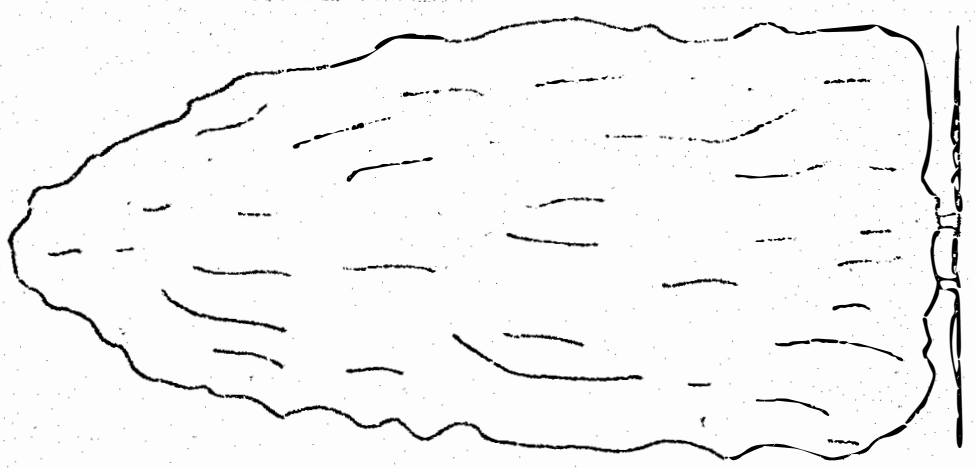

$\frac{7}{8}$

ટ્ધ

2

0

त्र

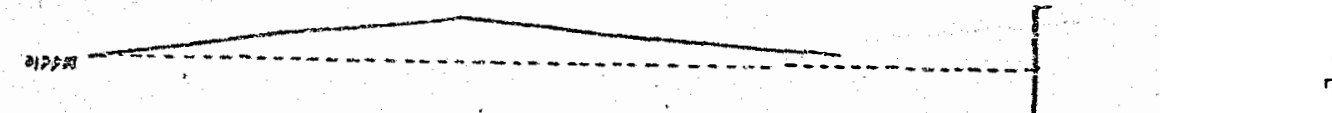

d

6

Co/so
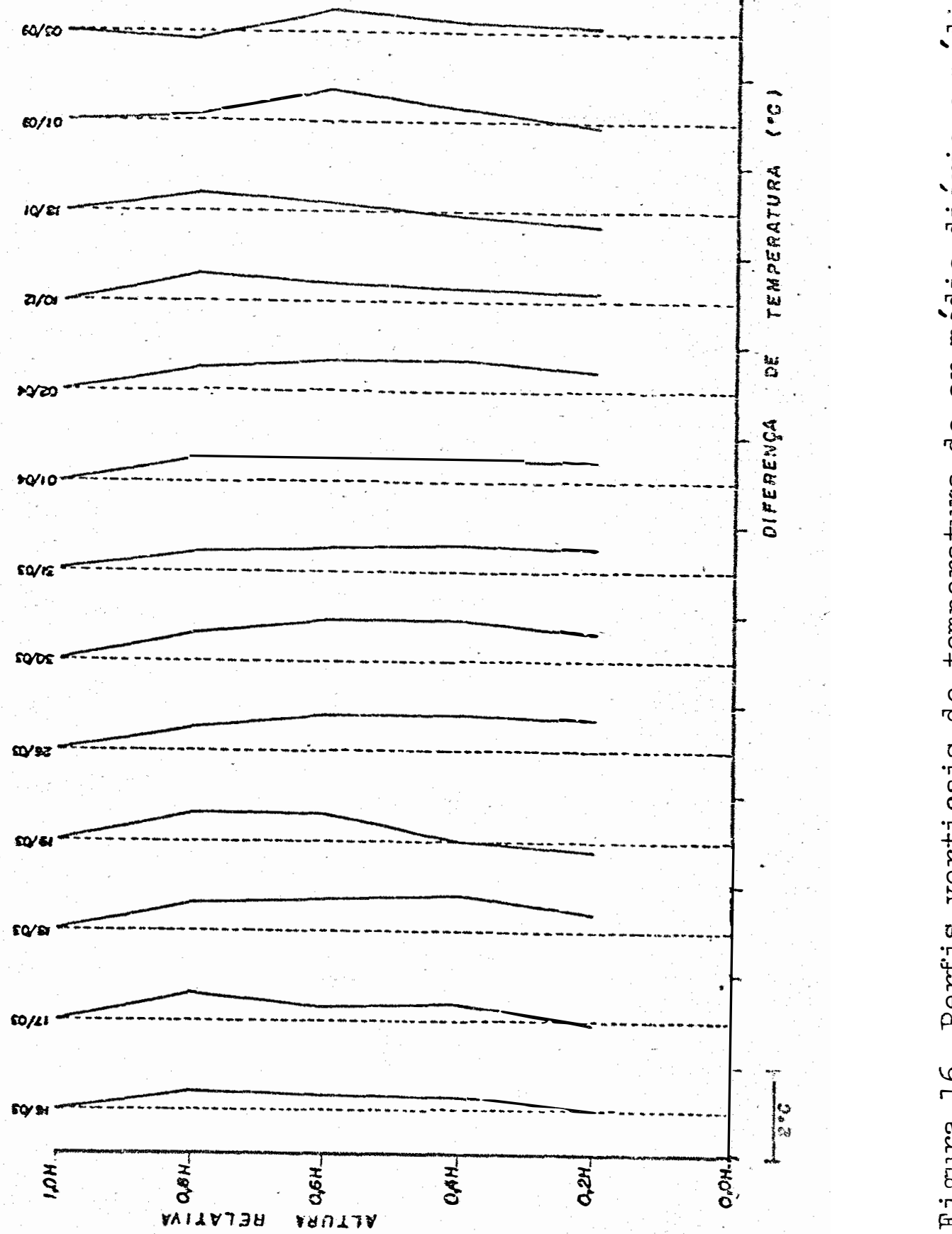
outros níveis em relação a êle。

A comparação entre os perfis revela que ocorreu un perfil inverso entre os níveis de $0,2 \mathrm{H}$ e $0,4 \mathrm{H}$ em todos os dias do período de ensaio. Entre os níveis de $0,4 i \mathrm{H}$ e $0,6 \mathrm{H}$ verí ficou-se cinco dias com gradiente negativo, cinco dias com gra diente neutro e apenas três dias com gradiente positivo, reve lando a predominância dos gradientes negativos e neutros. En tre os núveis de $0,6 \mathrm{H}$ e $0,8 \mathrm{H}$ ocorreram sete dias com gradiente positivo, dois dias com gradiente neutro e apenas quatro dias com gradiente negativo, evidenciando que nesta camada predomi na o gradiente positivo. Entre os níveis de $0,8 \mathrm{H}$ e $1,0 \mathrm{H}$ o gra diente foi sempre positivo com exceção de um único dia.

Do ponto de rista médio do ensaio, as frequên cias de gradiente vertical de temperatura estão resumidos na tabela 14. Infere-se desta tabela que predominam os gradientes

Tabela 14. Frequêrcia de ocorrência diária dos gradientes ver ticais de temperatura do ar na cultura

\begin{tabular}{lccccccc}
\hline \multirow{2}{*}{ NIVEL } & \multicolumn{2}{c}{ POSITIVO } & & \multicolumn{2}{c}{ NEUTRO } & \multicolumn{2}{c}{ NEGATIVO } \\
\cline { 2 - 5 } & no dias & $\%$ & & no dias & $\%$ & no dias & $\%$ \\
\hline $0,2 \mathrm{H}-0,4 \mathrm{H}$ & 0 & 0 & 0 & 0 & 13 & 100 \\
$0,4 \mathrm{H}-0,6 \mathrm{H}$ & 3 & 24 & 5 & 38 & 5 & 38 \\
$0,6 \mathrm{H}-0,8 \mathrm{H}$ & 7 & 54 & 2 & 1 & 4 & 31 \\
$0,8 \mathrm{H}-1, \mathrm{OH}$ & 12 & 92 & & 0 & 0 & 1 & 8 \\
\hline
\end{tabular}


negativos entre os níveis de 0,2 e $0,4 \mathrm{H}$, com $100 \%$ de frequên cia; neutro ou negativo, entre os níveis de $), 4$ e o,6H com 38\% de frequência cada e positivo entre os níveis de 0,6 a 1,0H com uma frequência de $54 \%$ e $92 \%$, respectivamente, entre os ní veis $0,6-0,8 \mathrm{H}$ e 0,8-1,0H。 De uma maneira geral, os gradientes são inversos abaixo de $0,4 \mathrm{H}$, normais acima de $0,6 \mathrm{H}$ e neutros ou negativos na parte média das plantas.

6.2.5. Análise de Variância da Temperatura Média Diá ria do Ar

A análise de variância dos valores ce temperatu彑 ra média diária do ar, contidos na tabela 8 , é mostrada na ta bela 15 .

Tabela 15. Análise de variância da temperatura méaia diária do ar na cultura.

Causa da Variação

G.I。

$S \cdot Q$ 。

$Q \cdot M$ 。

F

SIG

\begin{tabular}{lrrrrr} 
Tratamentos (níveis) & 4 & 2,52 & 0,63 & 16,83 & $5 \%$ \\
Blocos (dias) & 12 & 871,29 & 72,61 & 1936,86 & $5 \%$ \\
Resíduo & 48 & 1,80 & 0,04 & & \\
\hline TOTAL & 64 & 875,61 & & \\
\hline
\end{tabular}


A significância entre blocos mostra que o perío do de ensajo abrangeu dias com temperetura r dia distinta. Com respeito aos tratamentos, a significância indica que a tempera tura média diária variou com a altura na cultura.

A comparação das médias diárias da tabela 8, pe lo teste de DUNCAN ao nível de 5\% de probabilidade, mostrou que os 13 dias de ensaio englobaram 8 condições térnicas esta tisticamente diferentes conforme é mostrado na tabela 16. A comparação das temperaturas médias nos cinco níveis mostrou que não há diferença significativa entre os níveis de 0,4 a $0,8 \mathrm{H}$ e que estes valores diferem dos obtidos nos níveis de 0,2 e 1,OH. Para o período de ensaio às temperaturas médias foram: $22,3^{\circ} \mathrm{C}, 22,6^{\circ} \mathrm{C}$ e $22,1^{\circ} \mathrm{C}$, respectivamente para a saia, região central e tôpo da planta

6.2.6. Perfis Verticais de Temperatura Máxima Diária do Ar

Os perfis verticais de temperatura máxima diá ria do ar, construídos a partir da tabela 9 , estäo representą dos na figura 17 .

Esta figura mostra que durante o período de en saio houve uma gama muito grande de variação no vilor de tempe ratura máxima. Os perfis mostraram uma variabilidade muito grande de forma, não definindo rigidamente o nível de ocorrência dos maiores valores.

A análise da frequência de ocorrência das tempe raturas máximas, calculada da tabela 9, mostra que os maiores 


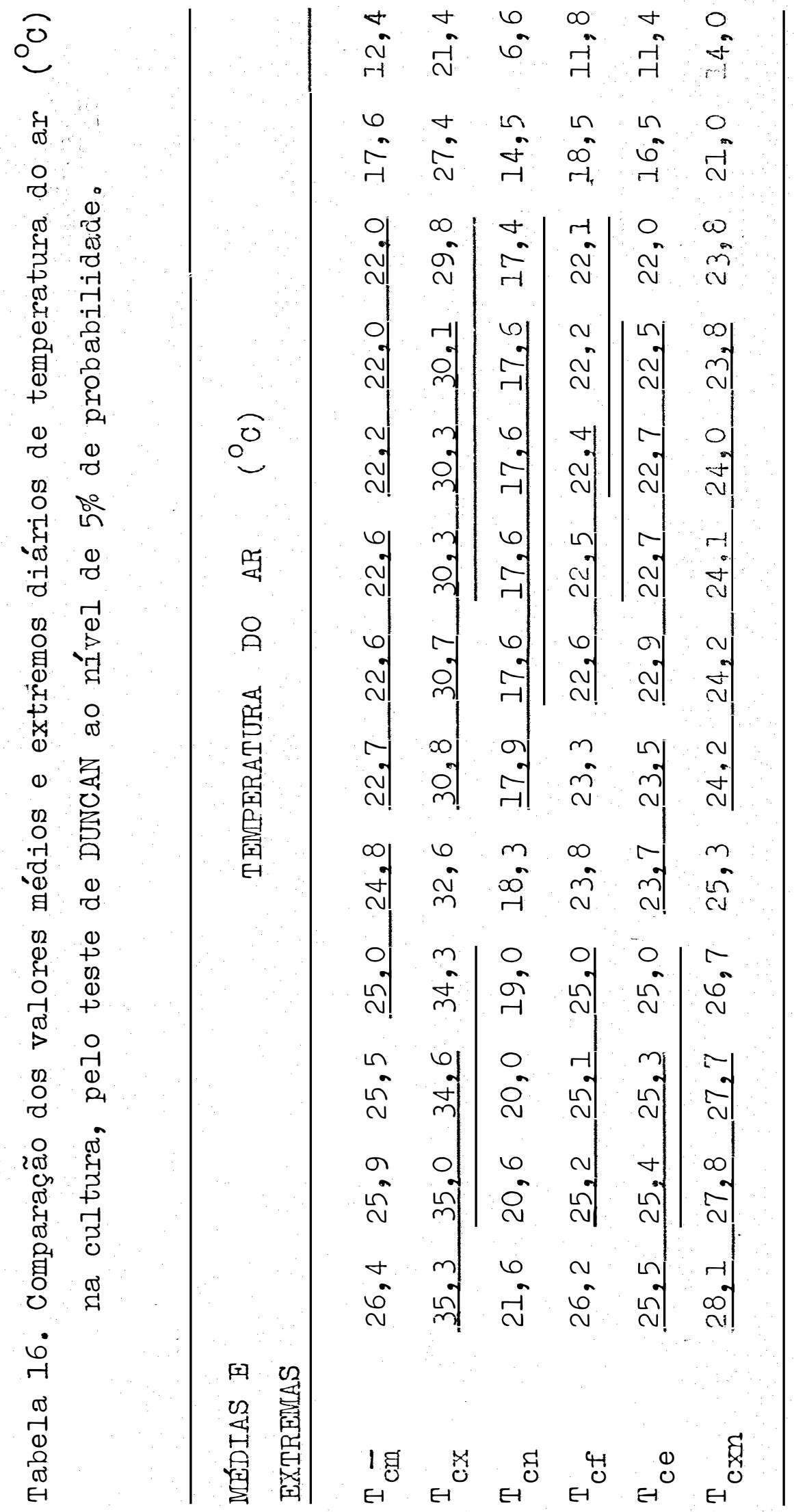


.66

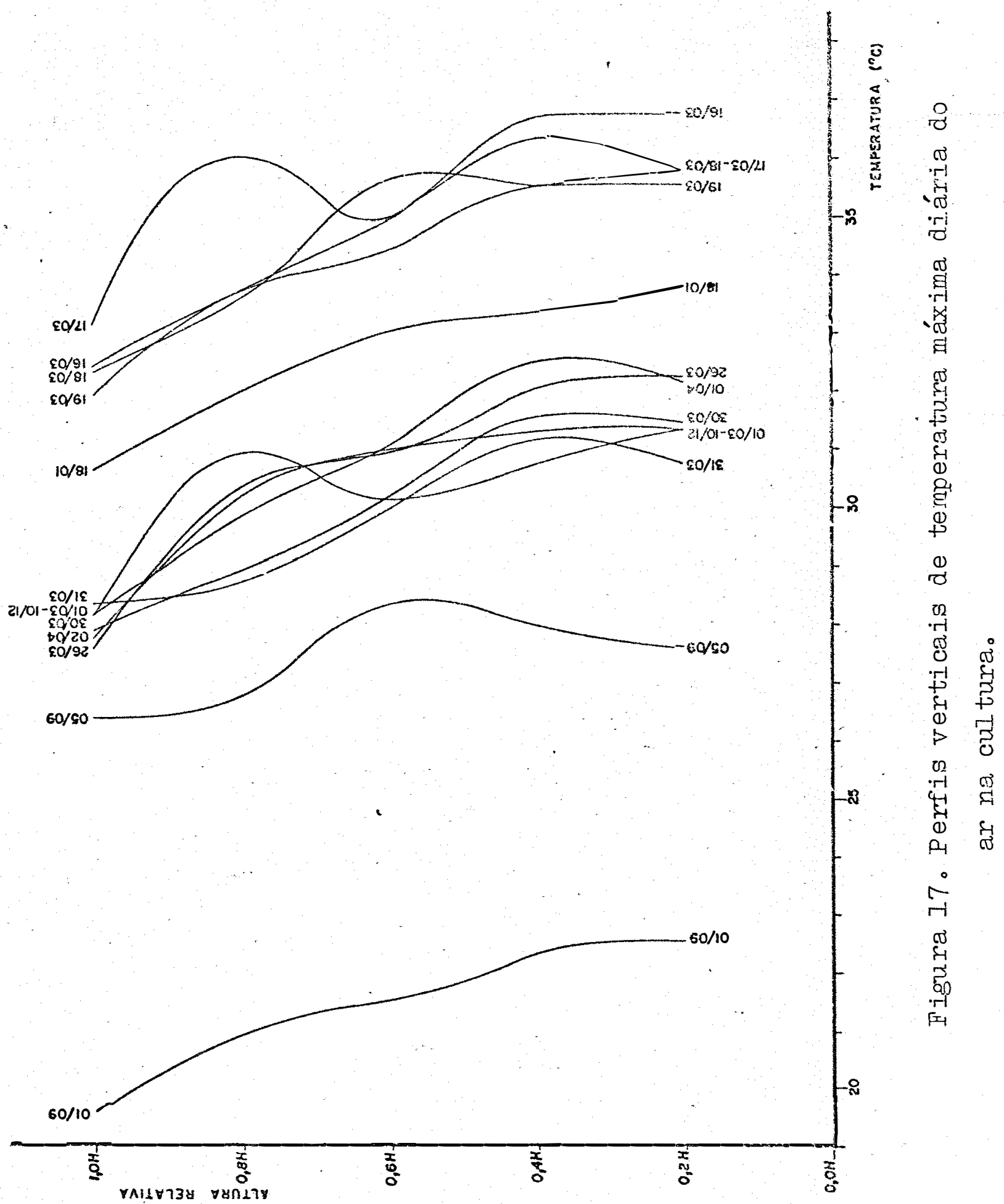


valores ocorreram no niveI de 0,2H ria proporg̃o ae 50\%; 44\% e 6\% ocorreram respectivamente para os nivejs 0,4H e 0, 6H. Valo res de segunda ordem ocorreram en 44\% dos dias no nível $\mathrm{O}, 4 \mathrm{H}$, 38\% no nível ảe 0,25, $12 \%$ no nível de $0,8 \%$ e $6 \%$ no nívei de 0,6H. Valores de terceira orâem na proporç̋̃o de 70\%, $15 \%$ : 15\%, respectivamente nos níveis $0,6 \mathrm{H}, 0,4 \mathrm{H}$ e 0,2H. Valores de quarta ordem ocorreram 85\% no nível 0,6H. Os menores valores de temperatura máxima ocorreram, em todos os aias; no nível de $1, \mathrm{OH}$.

Em ordem crescente de grandeza, as maiores tem peraturas máximas tem maior frequência de ocorrêncìa nos ní veis $0,8 \mathrm{H}, 0,6 \mathrm{H}, 0,4 \mathrm{H}$ e $0,2 \mathrm{H}$, mostrando em termos médios, um incremento positivo nas temperaturas máximas no sentido de $1, \mathrm{OH}$ para $\mathrm{\rho}, 2 \mathrm{H}$.

5.2.7. Análise de Variância da Temperatura Máxima Diá ria do Ar

A análise de variância dos valorés ciários de temperatura máxima do ar, contidos na tabela 9, é mostrada na tabela 17 .

A significância entre blocos mostra que os pẹ fis diários de temperatura máxima deferiram entre si, fato que também pode ser inferido na figura 17. A comparação das médias dos blocos entre si, pelo teste de DUNCAN, mostro que ocorreram 7 condições estatisticamente distintas de temperatura má xima média diária do ar na cultura, conforme mostre a tabela 16. 
Tabela 17. Análise de variância da temperatura máxima diária do ar na cultura.

Causa da Variação

G.I. S.Q.

Q.Mo

F SIG

Tratamentos (níveis)
Blocos (dias)
Resíduo

TOTAT

$\begin{array}{rrrrr}4 & 99,07 & 24,77 & 83,16 & 5 \% \\ 12 & 841,67 & 70,14 & 235,50 & 5 \% \\ 48 & 14,30 & 0,30 & & \end{array}$

64955,04

A significância de tratamentos indica que a tem peratura máxima diária variou com a altura na cultura. Comparan do-se estas temperaturas, pelo teste de DUNCAN, verifica-se que não há diferença significativa entre os níveis 0,2 e $0,4 \mathrm{H}$ e estes diferem dos demais níveis. Para o período de ensaio,as temperaturas máximas médias diárias foram $32,2^{\circ} \mathrm{C}$ para a região entre os níveis $0,2 \mathrm{H}$ a $0,4 \mathrm{H}, 31,3^{\circ} \mathrm{C}$ para 0 nível ce $0,6 \mathrm{H}$, $30,5^{\circ} \mathrm{C}$ para o nível de $0,8 \mathrm{H}$ e $28,8^{\circ} \mathrm{C}$ para o tôpo da planta.

6.2.8. Ferfis Verticais de Temperatura Nínima Diária do Ar

Os perfiis verticais de temperatura mínima diá ria do ar, construídos a partir da tabela 9 , estão representa dos na figura 1.8. 
.69.

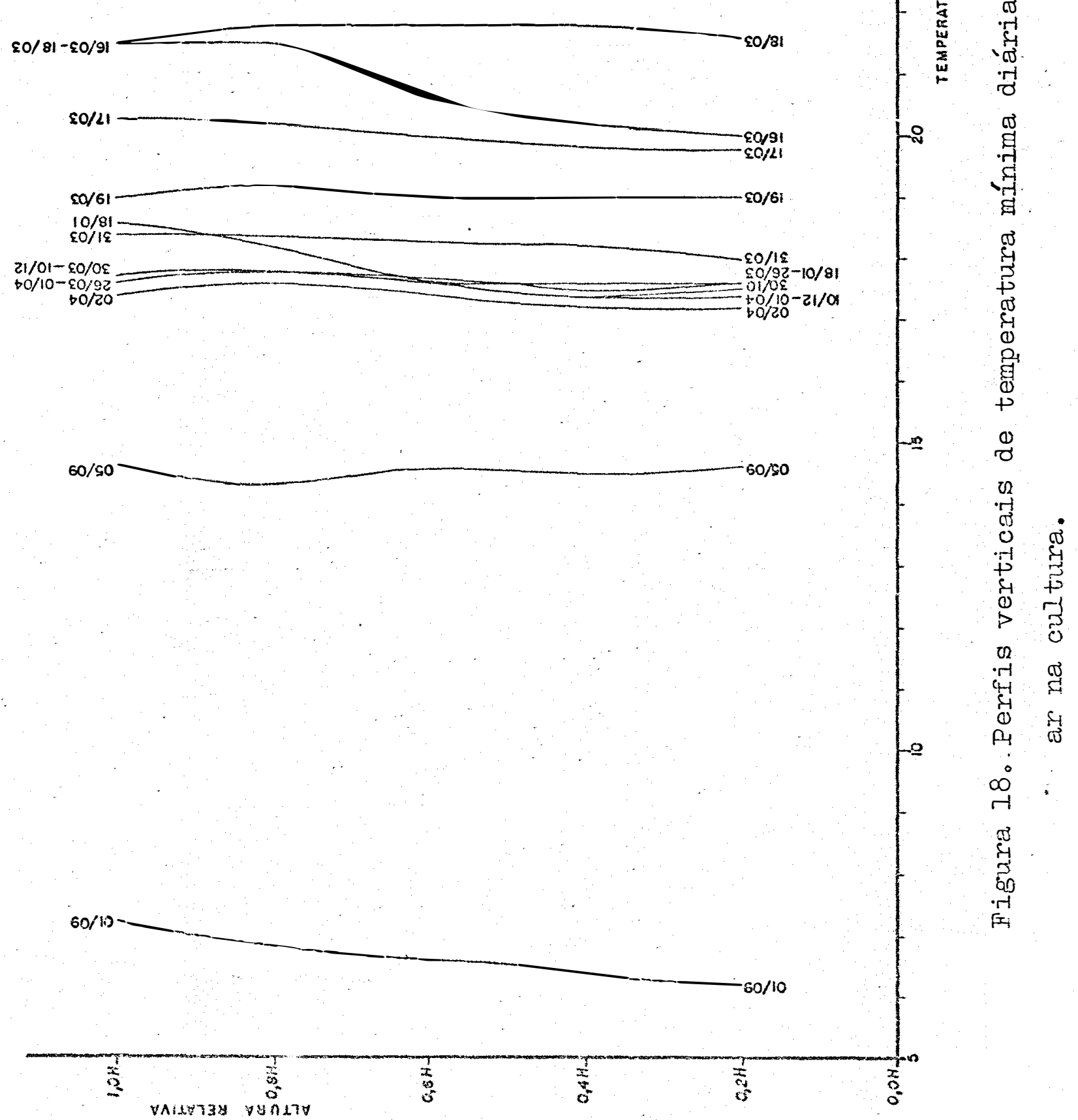


Esta figura mostra gue ocorreu uma grande gama de variøsão no valor da temperatura mínima. os perfis mostra ram pouca variação de forma, refletināo, em contraste aos de temperatura máxima, que as condições de ocorrêncie da tempera tura mínima foram bastante semelhantes entre os alas. A forma dos perfis mostra uma pequena taxa de variaçäo no valor da tem peratura mínima com a altura, indicando uma condiçấo homogienea de ocorrência.

A pequena variação nos valores de temperatura mínima no perfil gera uma grande variabilidade da ordem de 은 corrência daquela temperatura nos diferentes níveis. Contudo, em termos médios, os valores mais baixos de tempere.tura mínima de primeira e segunda ordem, ocorreram nos níveis 0,2 e $0,4 \mathrm{H}$ na mesma frequência. Valores de terceira ordem de grandeza o correram no nível de $0,6 \mathrm{H}$. Os de quarta ordem, no nível de l, OH. Valores de quinta ordem ocorreram no nível de $0,8 \mathrm{H}$.

Em ordem crescente de grandeza, as temperaturas mínimas tiveram maior frequência de ocorrência nos níveis de 0,2 e $0,4 \mathrm{H}, 0,6 \mathrm{H}, 1, \mathrm{OH}$ e $0,8 \mathrm{H}$.

\subsubsection{Análise de Variância da Temperetura Mínima Diá ria do Ar}

A análise de variância dos dados àe temperatura mínima diária do ar, contidos na tabela 9 , $\varepsilon$ mostrada na tabe 1 a 18. 
.71 。

Tabela 18. Análise de variância da temperatura mínima diária do ar na cultura.

Causa de Variação

G.I.

S.Q. Q。 Mo

F

SIG

Tratamentos (níveis)

4

1,41

0,35

7,50

$5 \%$

Blocos (dias)

12

812,09

67,67

1435,95

$5 \%$

Resíduo

48

2,26

0,05

TOTAL

$64 \quad 815,77$

A significância entre blocos indica que os per fis diárics de temperaturá mínima diferiram entre si. A compa ração das médias dos blocos entre si, pelo teste de DUNCAN, mostra que ocorreram 9 condições estatisticamente distintas de temperatura mínima média diária do ar na cultura, conforme é mostrado na tabela 16 。

A significância dos tratamentos mosira que as diferenças de temperatura mínima no perfil vertical são esta tisticamente significante. A comparação da distribuição vertitical de temperatura mínima, pelo teste de DUITCAN; nostra que os valores não diferiram entre os níveis $0,8 \mathrm{H}, 1,0 \mathrm{H}$ e 0,6H; entre os níveis $1,0 \mathrm{H}, 0,6 \mathrm{H}$ e $0,4 \mathrm{H}$ e entre os níveis $0,6 \mathrm{H}, 0,4 \mathrm{H}$ e $0,2 \mathrm{H}$, e que estas regiões diferiram entre si. Os menores va lores de temperatura mínima ocorreram na região meis kaixa da planta, aumentando em direção ao nível 0,8H e diminuindo em di reção a 1,OH. A temperatura mínima média do ensaico soi $17,2^{\circ} \mathrm{C}$ 
e $17,6^{\circ} \mathrm{C}$, respectivamente nos níveis $0,2 \mathrm{H}$ e $0,8 \mathrm{H}$.

6.2.10. Pstimativa da Temperatura Média Dínia do Ar na Cultura

A tabela 10 mostra os valores de temiperatura mé dia diária do ar, nos cinco níveis na cultura, caloulados uti lizando os modelos do Serviço Nacional de Nieteorologia, Insti tuto Agronômico de Campinas e temperaturas extremas:

Para cada sistema de cálculo da temperatura mé dia do ar, confeccionou-se uma análise de variâncił: semelhante aquela realizada para a temperatura média verdadeira, descrita em 6.2.5. A separação, pelo teste de DUNCAN, das médias dos blocos (dias) está mostrada na tabela 16 e das médìas dos tra tamentos (níveis) na tabela 19.

Tabela 19. Comparação entre a temperatura média diária do ar nos cinco níveis na cultura, pelo teste de DUNCAN ao nível de 5\% de probabilidade.

MÉDIAS TENRERATURA DO AR $\left({ }^{\circ} \mathrm{C}\right)$

\begin{tabular}{llllll}
\hline $\mathrm{T}_{\mathrm{cm}}$ & 22,6 & 22,6 & 22,5 & 22,3 & 22,1 \\
\cline { 2 - 6 } $\mathrm{T}_{\mathrm{cf}}$ & $\underline{22,6}$ & $\frac{22,6}{22,4}$ & 22,4 & 21,9 \\
$\mathrm{~T}_{\mathrm{ce}}$ & $\underline{22,4}$ & 22,4 & 22,3 & $\underline{22,2}$ & 21,9 \\
$\mathrm{~T}_{\mathrm{cxn}}$ & $\underline{24,7}$ & 24,7 & 24,4 & 24,0 & 23,2 \\
\hline
\end{tabular}


Tabela 20. Coeficiente linear (a), angular (b) e de correlação $(r)$, teste "t" e significância d "rn"e desvio pa drão, para as regressões Iineares entre os valores estimados e veraadeiros dé temperatura nédia ao ar na cultura.

\begin{tabular}{|c|c|c|c|c|c|c|c|c|}
\hline \multirow{2}{*}{$\begin{array}{c}\mathrm{y} \\
\left({ }^{\mathrm{O}} \mathrm{C}\right)\end{array}$} & \multirow{2}{*}{$\begin{array}{c}x \\
\left({ }^{O} \mathrm{C}\right)\end{array}$} & \multirow{2}{*}{ NIVEL } & \multicolumn{6}{|c|}{$y=a+b \circ x$} \\
\hline & & & $r$ & a. & 3 & $t(r)$ & sig & $\mathrm{Sy} \cdot \mathrm{x}$ \\
\hline \multirow[t]{5}{*}{$\mathrm{T}_{\mathrm{cm}}$} & \multirow[t]{5}{*}{$\mathrm{T}_{\mathrm{cf}}$} & $0,2 \mathrm{H}$ & 0,99 & 0,66 & 0,97 & 21,6 & $1 \%$ & 0,60 \\
\hline & & $0,4 \mathrm{H}$ & 0,98 & $-0,22$ & 1,01 & 18,4 & $1 \%$ & 0,71 \\
\hline & & $0,6 \mathrm{H}$ & 0,98 & $-0,03$ & 1,00 & 16,5 & $1 \%$ & 0,77 \\
\hline & & $0,8 \mathrm{H}$ & 0,99 & $-0,70$ & 1,03 & 24,4 & $1 \%$ & 0,56 \\
\hline & & $\mathrm{I}, \mathrm{OH}$ & 0,99 & $-0,53$ & 1,03 & 22,5 & $1 \%$ & 0,58 \\
\hline \multirow[t]{5}{*}{$\mathrm{T}$ cm } & \multirow[t]{5}{*}{$\mathrm{T}_{\text {ce }}$} & $0,2 \mathrm{H}$ & 0,98 & 1,58 & 0,93 & 17,8 & $1 \%$ & 0,73 \\
\hline & & $0,4 \mathrm{H}$ & 0,97 & 1,56 & 0,94 & 13,2 & $1 \%$ & 0,96 \\
\hline & & $0,6 \mathrm{H}$ & 0,98 & 2,35 & 0,91 & 15,2 & $i \%$ & 0,83 \\
\hline & & $0,8 \mathrm{H}$ & 0,98 & 1,62 & 0,93 & 18,7 & $1 \%$ & 0,72 \\
\hline & & $1,0 \mathrm{H}$ & 0,99 & 1,43 & 0,95 & 20,8 & $1 \%$ & 0,62 \\
\hline \multirow[t]{5}{*}{$\mathrm{T}_{\mathrm{cm}}$} & \multirow[t]{5}{*}{$\mathrm{T}_{\mathrm{cxn}}$} & $0,2 \mathrm{H}$ & 0,99 & $-2,48$ & 1,00 & 20,3 & $1 \%$ & 0,64 \\
\hline & & $0,4 \mathrm{H}$ & 0,98 & $-2,15$ & 1,00 & 18,8 & $1 \%$ & 0,69 \\
\hline & & $0,6 \mathrm{H}$ & 0,98 & $-1,50$ & 0,99 & 16,6 & $1 \%$ & 0,76 \\
\hline & & $0,8 \mathrm{H}$ & 0,98 & $-2 ; 69$ & 1,05 & 17,5 & $1 \%$ & 0,77 \\
\hline & & $I, 0 \mathrm{H}$ & 0,98 & $-2,37$ & 1,06 & 27,9 & $1 \%$ & 0,72 \\
\hline
\end{tabular}


Pela tabela 16 verifica-se que os modelos de cálculo discriminaram difexentenexte as diversas condições tér micas. Esta ocorreu tanto no número de condjõos quanto no a grupamento dos dias. Pela tabela 19 verificamse que o mesmo correu quando se compararam as condições térnicas nos diferen tes níveis. Isso mostra que as médias estimadas tiveram compor tamento diferente do da média verdadeira.

Com as tabelas 8 e 10 calcularam-se os desvios entre os valores estimados em relação ao valor verdadeiro, cu jos histogramas estão apresentados na figura 19.

Verifica-se, para a maioria dos dias, que as temperaturas médias estimadas sobre estimaram o valor verda deiro e os desvios diminuiram do nível de $0,2 \mathrm{H}$ pare o nível de 1, $\mathrm{OH}$. Dentre estes, o método das temperaturas extremas apresen tou os maibres desvios, cujos valores foram positivos.

Os resultados da análise de regressão linear en tre as temperaturas médias estimadas e a temperatura média ver dadeira estão contidos na tabela 20. As equações obtidas foram significantes ao nível de $1 \%$ de probabilidade, indicando que os dois parâmetros estão estreitamente correlacionados. Estas equações permitem estimar a temperatura média diária verdadei ra do ar em um determinado nível na cultura, através das leitú ras das 07, 14 e 21 horas ou através das leituras das 09 e 21 horas e temperaturas extremas ou somente através das temperatu ras extremas. 

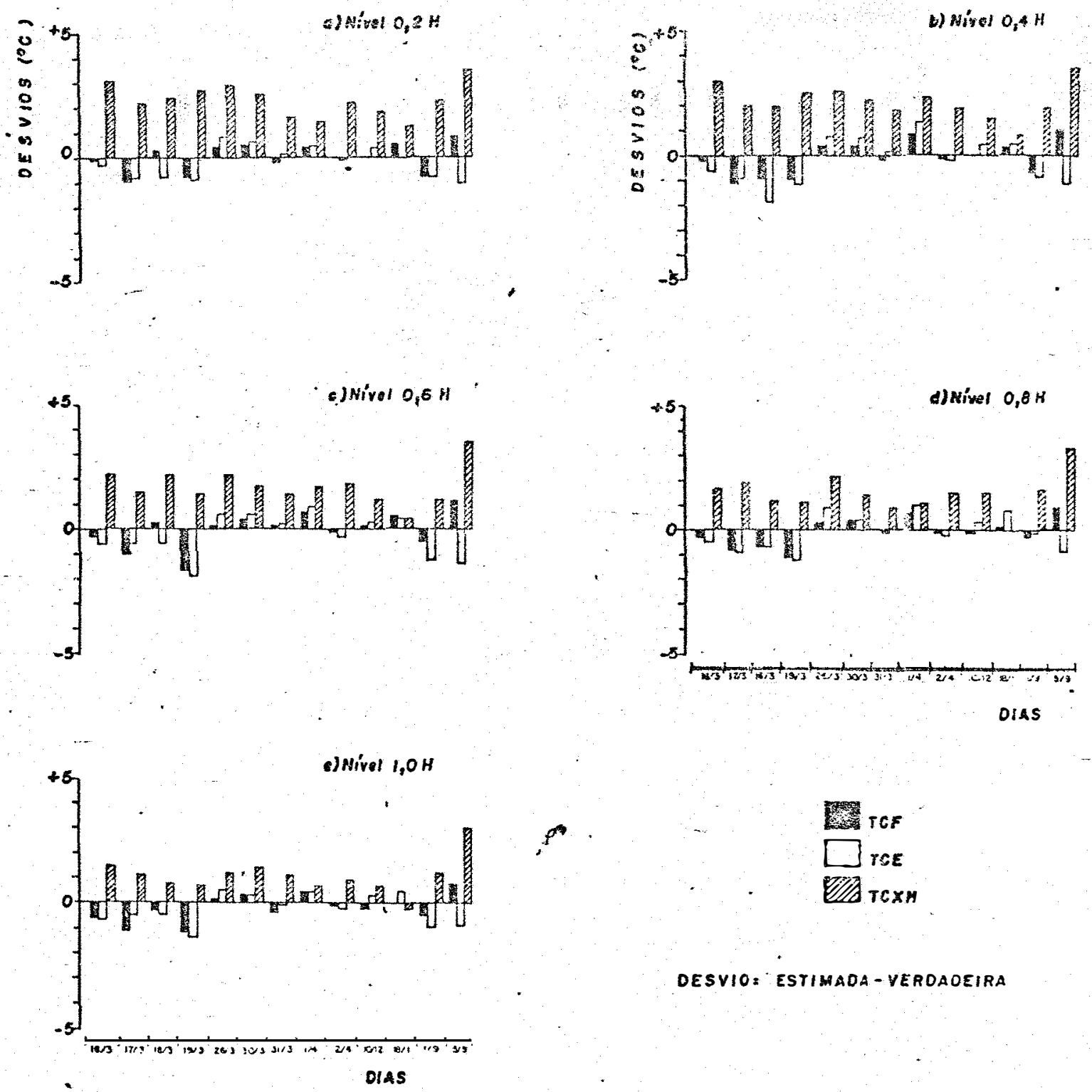

Figura 19. Histogramas dos desvios entre os valores estimados e verdadeiros da temperatura média do ar na cultu ra。 
6.3. Relações de Temperatura do Ar entre o Posto Meteorcló gico e a Cultura

\subsubsection{Temeraturas viéaiias}

Com as tabelas 8 e 11 calcularam-se os desvios entre os valores do posto em relação aos valores verdadeiros na cultura, cujos histogranas são apresentaāos na Figura 20.

Constatoume que quando se utiliza as temperatu: ras extremas do posto para o cálculo das nédias, ocorrem os maiores desvios, cujos valores são sempre positivos. Neste sis tema de cálculo, a temperatura média no posto mostra-se sempre superior a temperatura verdadeira na cultura em toóos os ní veis. Quando se emprega o modelo de cálculo do IAC, os desvios entre o posto e a cultura são.menores que no caso anterior,pre dominando os desvios positivos nos níveis de 0,2 e os negativos nos níveis $0,6 \mathrm{H}$ e 0,8H. Portanto, a temperatura do posto mostra-se menor que a temperatura da cultura na parte média, e maior nas regiões da saia e tôpo da planta. Os des vios entre as temperaturas estimadas no posto, pejos modelos do IAC e DENET e os valores verdadeiros na cultura diferem mui to pouco. Quando se usa o sistena de cálculo do DENET, ocorrem - predominio dos desvios positivos nos níveis de 0,2 e 1, OH, e negativos na região de 0,4 a 0,8H. Isto indica que a temperatu ra no posto mostra-se maior que o valor verdadeiro na saia e topo da planta e menor nos demais níveis.

A variação do comportamento dos desvios entre a temperatura estimada no posto, pelos diferentes métodos, e a temperatura verdadeira na cultura mostra que não e possível a 

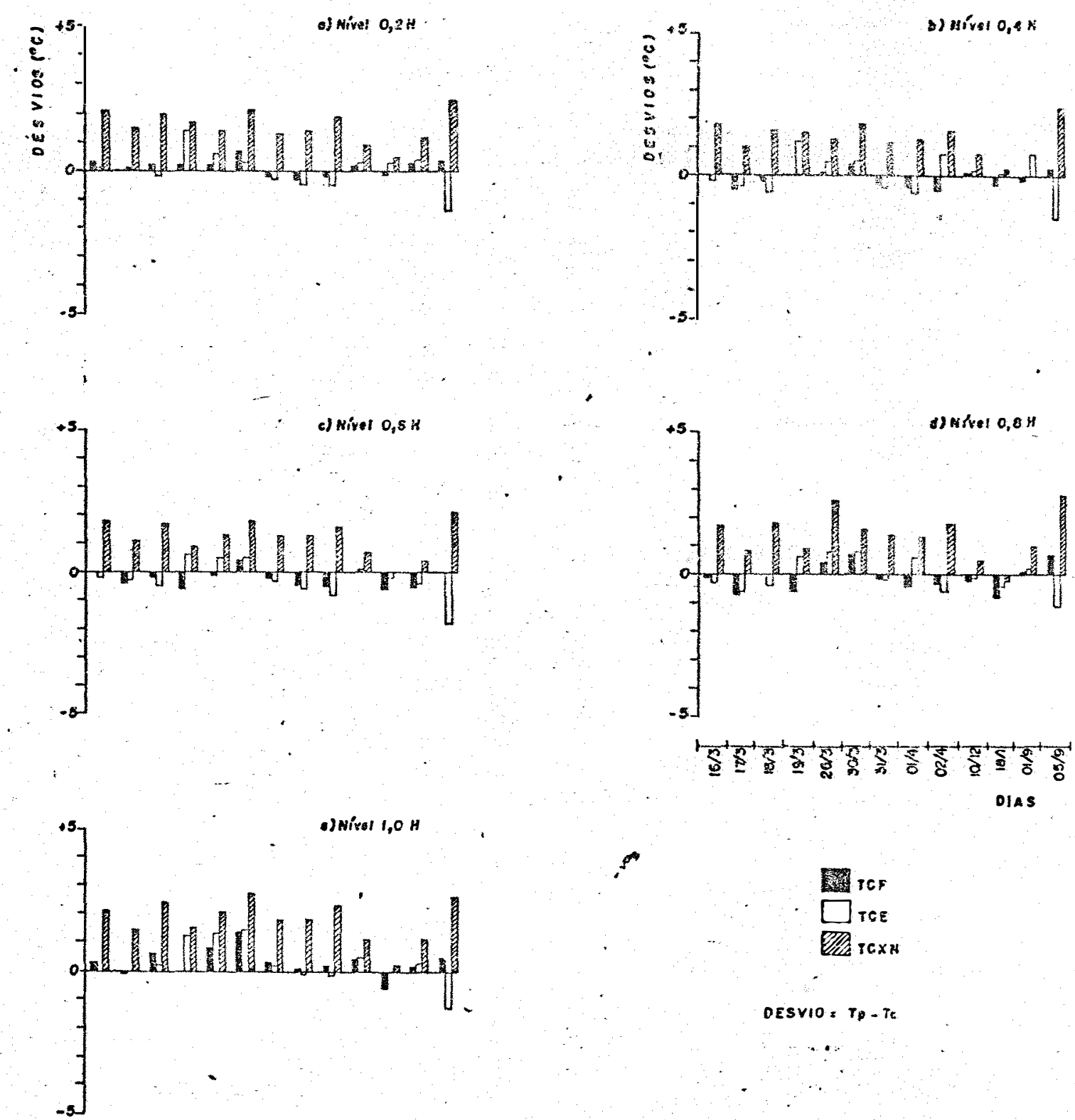

s.

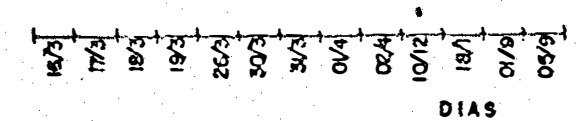

Figura 20. Histogramas dos desvios das temperaturas do ar mé dias diárias, calculados a partir de ofservações no posto meteorológico, em relação à temperatura do ar média verdadeira, em cinco níveis na cultura. 
simples transferência de valores, mas evidencia que pode exjs tir uma relação entre estas temperaturas.

Os resultados da análise de regressão linear das temperaturas médias estimadas no posto meteorológico e a temperatura méáia verdádeira na cultura estão contidos na tabe. la 2l. Os valores dos coeficientes de correlação são estatisti camente significantes indicando que a condição microclimática está bastante correlacionada com a condição macroclimática. ES tas equações permitem estimar a temperatura nédia verdadeira do ar no interior da cultura, em diferentes níveis, através das temperaturas do ar comunente lidas nos postos reteorológi$\cos$.

\subsubsection{Temperaturas Extremas}

Com as tabelas 9 e $I I$ calcularam-se os desvios entre os valores das temperaturas na cultura em relação ao pos to meteorológico, cujos histogramas estão apresentados na figu ra 21.

Verifica-se que a temperatura máxima na cultura foi sempre superior à máxima do posto, entre os níveis de 0,2 a $0,8 \mathrm{H}$, sendo que só em três dias a temperatura do posto su plantou a da cultura neste último nível. Para o nível de 1, OH, as temperaturas da cultura foram superiores às do posto em quatro dias e inferiores nos outros nove dia:s. Assim, a tempe ratura máxima diária atinge maiores valores na cultura que no posto meteorológico, com exceção do tôpo das plantas que tende a apresentar valores menores. 
Tabela 21. Coeficiente Iinear (a): anguiar (b) e de correlação (r): teste "t" e significância d "x" e desvio pa drão para as regressões lineares entre a temperatura média verdadeira na cuztura e as temperaturas iné dias no posto meteorológico segundo os nodelos do DENEI, IAC e tempera.turas extremas.

\begin{tabular}{|c|c|c|c|c|c|c|c|c|}
\hline $\mathrm{y}$ & & NIVEL & & $\mathrm{y}$ & $a+b$ & - $x$ & & \\
\hline$\left({ }^{\mathrm{O}} \mathrm{C}\right)$ & $\left({ }^{\mathrm{O}} \mathrm{C}\right)$ & & $r$ & $a$ & b & $t(x)$ & sigg & $S y \cdot x$ \\
\hline $\mathrm{T} \overline{\mathrm{cm}}$ & ${ }^{\mathrm{T}} \mathrm{pf}$ & $0,2 \mathrm{H}$ & 1,00 & $-0,46$ & 1,015 & 45,5 & $1,0 \%$ & 0,29 \\
\hline $\mathrm{T}$ cm & $\mathrm{T}_{\mathrm{pf}}$ & $0,4 \mathrm{H}$ & 1,00 & $-0,28$ & 1,017 & 44,5 & $1,0 \%$ & 0,30 \\
\hline$T_{c \cdot m}$ & $T_{p f}$ & $0,6 \mathrm{H}$ & 1,00 & $-0,37$ & 0,993 & 39,7 & $1,0 \%$ & 0,32 \\
\hline $\mathrm{T} \mathrm{cm}$ & $T_{n f}$ & $0,8 \mathrm{H}$ & 0,99 & $-1,16$ & 1,056 & 29,8 & $1,0 \%$ & 0,46 \\
\hline $\mathrm{T}$ cm & $\mathrm{T}_{\mathrm{pf}}$ & I, O H & 0,99 & $-0,56$ & 1,010 & 28,7 & $1,0 \%$ & 0,45 \\
\hline $\mathrm{T} \overline{\mathrm{cm}}$ & ${ }^{\mathrm{T}}$ pe & $0,2 \mathrm{H}$ & 0,99 & 1,27 & 0,939 & 19,0 & $1,0 \%$ & 0,68 \\
\hline $\mathrm{T}_{\mathrm{cm}}$ & $\mathrm{T}_{\mathrm{pe}}$ & $0,4 \mathrm{H}$ & 0,98 & 1,44 & 0,942 & 19,2 & $1,0 \%$ & 0,68 \\
\hline $\mathrm{T} \mathrm{cm}$ & $\mathrm{T}_{\mathrm{pe}}$ & $0,6 \mathrm{H}$ & 0,99 & 1,95 & 0,923 & 21,7 & $1,0 \%$ & 0,59 \\
\hline$T_{\mathrm{cm}}$ & $\mathrm{T}_{\mathrm{pe}}$ & $0,8 \mathrm{H}$ & 0,99 & 0,48 & 0,985 & 22,2 & $1,0 \%$ & 0,61 \\
\hline $\mathrm{T}$ cm & $\mathrm{T}_{\mathrm{pe}}$ & I,O H & 0,98 & 1,10 & 0,938 & 18,4 & $1,0 \%$ & 0,70 \\
\hline $\mathrm{T}_{\mathrm{cm}}$ & & $0,2 \mathrm{H}$ & 0,99 & $-1,10$ & 0,980 & 23,0 & $1,0 \%$ & 0,57 \\
\hline $\mathrm{T} \overline{\mathrm{cm}}$ & $\mathrm{T}_{\mathrm{p} \times n}$ & $0,4 \mathrm{H}$ & 0,99 & $-0,94$ & 0,983 & 23,3 & $1,0 \%$ & 0,56 \\
\hline $\mathrm{T} \overline{\mathrm{cm}}$ & & $0,6 \mathrm{H}$ & 0,99 & $-0,23$ & 0,958 & 20,9 & $1,0 \%$ & 0,61 \\
\hline $\mathrm{T}_{\mathrm{cm}}$ & $\mathrm{T}_{\mathrm{pxn}}$ & $0,8 \mathrm{H}$ & 0,98 & $-1,70$ & 1,015 & 16,9 & $1,0 \%$ & 0,80 \\
\hline $\mathrm{T}$ cm & $\mathrm{T}_{\mathrm{pxn}}$ & $\mathrm{I}, \mathrm{OH}$ & 0,98 & $-1,13$ & 0,983 & 17,6 & $1,0 \%$ & 0,73 \\
\hline
\end{tabular}



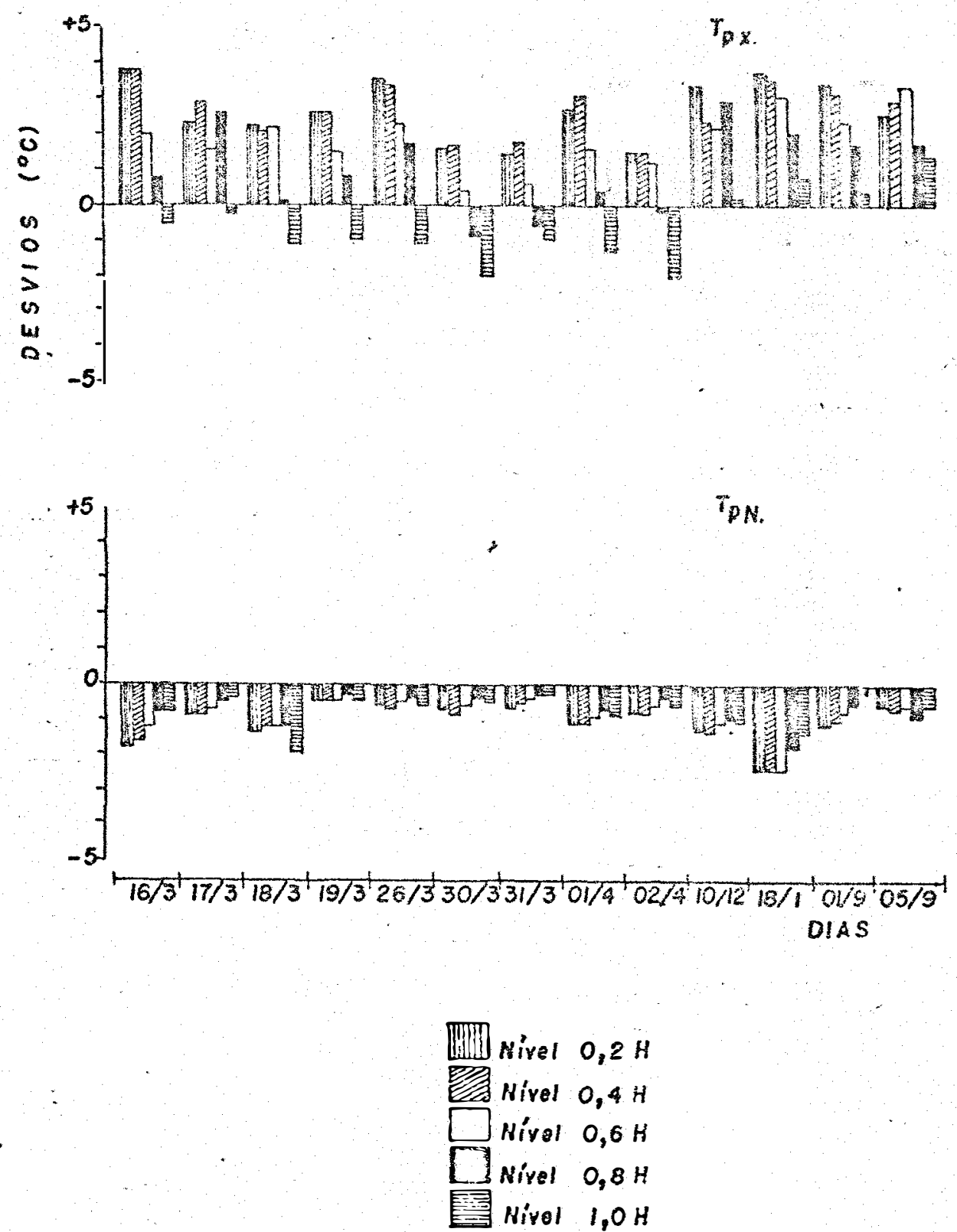

DESVIO $=T_{C}-T_{P}$

Figura 21. Histogramas dos desvios de temperaturas extremas na cuitura em re ação ao posto meteorológico. 
Observa-se que a iemperature mínima do ar na cultura foi sempre inferior aos valoxes obswedas no posto ine teorológico, com uma tenâencia aos desvios aumentaxem do topo para o interior da cultura. Dessa forma, as tempenaturas míni mas ocorridas na cultura são de valores menores que as observa das no posto.

Tabela 22. Coeficiente linear (a), angular (b) e de correlação $(r)$, teste "t" e significância de "rn" de desvio pa drão para as regressões lineares entre as temperatu ras extremas diárias observadas na cultura e no pos to meteorológico.

\begin{tabular}{|c|c|c|c|c|c|c|c|c|}
\hline \multirow{2}{*}{$\begin{array}{c}\mathrm{y} \\
\left({ }^{\mathrm{O}} \mathrm{C}\right)\end{array}$} & \multirow{2}{*}{$\begin{array}{c}\mathrm{x} \\
\left({ }^{\mathrm{O}} \mathrm{C}\right)\end{array}$} & \multirow{2}{*}{ NIVEI } & \multicolumn{6}{|c|}{$y=a+b \cdot x$} \\
\hline & & & $r$ & $a$ & $\mathrm{~b}$ & $t(r)$ & sig & $\mathrm{sy} \cdot \mathrm{x}$ \\
\hline $\mathrm{T}_{\mathrm{cx}}$ & ${ }^{\mathrm{T}} \mathrm{px}$ & $0,2 \mathrm{H}$ & 0,98 & 4.03 & 0,954 & 14,8 & $1,0 \%$ & 0,88 \\
\hline $\mathrm{T}_{\mathrm{cx}}$ & $\mathrm{T}_{\mathrm{px}}$ & $0,4 \mathrm{H}$ & 0,98 & 3,62 & 0,969 & 17,6 & $1,0 \%$ & 0,75 \\
\hline $\mathrm{T}_{\mathrm{cX}}$ & $\mathrm{T}_{\mathrm{px}}$ & $0,6 \mathrm{H}$ & 0,98 & 4,14 & 0,923 & 14,8 & $1,0 \%$ & 0,85 \\
\hline $\mathrm{T}_{\mathrm{cx}}$ & $\mathrm{T}_{\mathrm{px}}$ & $0,8 \mathrm{H}$ & 0,95 & 3,32 & 0,922 & 10,1 & $1,0 \%$ & 1,24 \\
\hline $\mathrm{T}_{\mathrm{cx}}$ & $\mathrm{T}_{\mathrm{px}}$ & $1,0 \mathrm{H}$ & 0,97 & 2,95 & 0,880 & 12,4 & $1,0 \%$ & 0,97 \\
\hline $\mathrm{T}_{\mathrm{cn}}$ & ${ }^{T}$ pn & $0,2 \mathrm{H}$ & 0,99 & $-0,50$ & 0,969 & 22,8 & $1,0 \%$ & 0,56 \\
\hline $\mathrm{T}_{\mathrm{cn}}$ & ${ }^{T}$ pn & $0,4 \mathrm{H}$ & 0,99 & $-0,45$ & 0,968 & 24,3 & $1,0 \%$ & 0,53 \\
\hline $\mathrm{T}_{\mathrm{cn}}$ & $\mathrm{T}_{\mathrm{pn}}$ & $0,6 \mathrm{H}$ & 0,99 & $-0,24$ & 0,965 & 3,8 & $1,0 \%$ & 0,53 \\
\hline $\mathrm{T}_{\mathrm{cn}}$ & $\mathrm{T}_{\mathrm{pn}}$ & $0,8 \mathrm{H}$ & 0,99 & $-0,27$ & 0,976 & 29,5 & $1,0 \%$ & 0,44 \\
\hline Ten & $\mathrm{T}_{\mathrm{pn}}$ & $\mathrm{I}, \mathrm{OH}$ & 0,99 & 0.57 & 0,958 & 27,7 & $1,0 \%$ & 0,43 \\
\hline
\end{tabular}


Desde que os desvios são positivos para a tempe ratura máxima e negativos para a temperatura mínima na cultura em relação ao posto, as amplitudes térmicas diárias são maio res na cultura. Considerando as variações àos àesvios com a aI tura da cultura, a amplitude térmica diária aumenta do topo em direção a saia das plantas.

Os resultados da análise de regressão linear en tre as temperaturas extremas observadas na cultura e no posto meteorológico estão inseridos na tabela 22. Todas as equações mostram-se significantes ao nível de $1 \%$ de probabilidade, indi cando que os dois parâmetros estão bastante correlacionados. Estas equações permitem estimar as temperaturas extremas diá rias na cultura, em função dos valores observados no posto me teorológico. 
.83.

\section{CONCLUSÕÉS}

O desenvolvimento deste trabalho, em safezal Mun do Novo cujas linhas tem orientação norte-sul e exposição oes te, plantado em terra roxa estruturada, com declividade de $8 \%$ em Botucatul-SP, permitiu chegar-se às seguintes conclusões:

7.1. Sobre a Temperatura das Folhas

a) A temperatura das folhas do cafeeiro, maior que a do ar circundande durante o período diumo e menor no período noturno. Inversões podem ocorrer em consequência da forração de orvalho e cobertura do céu.

b) A temperatura das folhas do cafeeiro depende da altura destas na cultura.

c) A maior temperatura máxima de folha e a me nor temperatura mínima ocorreram no nível co cespordente a 40\% da altura média das plantas.

d) A temperatura das foinas pode sex estimada 
a partir da temperatura do ar circundante na cultura, através de equações lineares de regressão.

c) O vento percorrido não se mostrou importante no estabelecimento dos desvios entre a temperatura das folhas e do ar.

7.2. Sobre a Temperatura do Ar no Cafezal

a) o curso diário da tempercitura do ar na cultü ra é semelhante ao curso diário da temperatura do ar num posto meteorológico。

b) A temperatura do ar na cultura aumenta com a altura durapte a noite e diminui durante o dia. As inversões dos gradientes ocorrem das 08 às 10 horas e das 16 às 18 horas.

c) A região da cultura onde ocorre o maior aque cimento e o maior resfriamento, abrange os níveis de 20\% a 40\% da altura das plantas.

d) A amplitude térmica diária decresce com a al tura.

e) Os gradientes verticais nédios diários de temperatura são inversos abaixo de 40\% da altura das plantas, normais acima de $60 \%$ e nevtros ou negativos ja perte média das plantas.

f) A temperatura média diária do ar na cultura varia com a altura。 
g) A temperatura máxima diária do ar na cultura ảecresce com a altura.

h) A temperatura mínima diária do ar na cultura cresce com a altura,

i) A temperatura do ar médic diária verdadeira na cultura pode ser estimada, através de equações lineares de regressão, em função da temperatura média, calcuisiáa pelos mo delos do DEMET, IAC ou das temperaturas extremas, a partir de temperatura do ar efetuadas na cultura.

7.3. Sobre as Relações da Temperatura do Ar entre o Posto Meteorológico e a cultura

a) A temperatura do ar média diária verdadeira na cultura, pode ser estimada através de equações lineares de regressão, em função da tenperatura média calculada pelos mode Ios do DEVIET, do IAC ou das temperaturas extremas, a partir de leituras de temperatura do ar efetuadas no posto metecroló gico.

b) As temperaturas do ar extremas diárias na cultura, podem ser estimadas através de equações lineares de re gressão, em função das leituras de temperaturas realizadas no posto meteorológico. 
.86.

\section{SUIMIARY}

This paper studies leaf and air thermal regimes in a coffee crop, with the end to achieve thermal relation ships between the crop and a meteorological station.

Coffee leaf temperature was measured at three levels, by copper-constantan thermocouples, inserted in the dorsal face nervure of the leaves. Air temperature was measu red, at five levels, by ventilated psychrometers, using mercu ry thermometers.

Coffee leaf temperature was higher than the surrounding air during the day and lower during the night. It may be evaluated from air temperature through linear regression equations。

Air temperature in the crop increased with height during the night and decreased during the day。 Gradient inversions occured between 08 and 10 hours and between 16 and 18 hours.

The crop region where heating was highest and 
cooling was lowest envolved the levels from $20 \%$ to $40 \%$ of plants height.

In a daily basis, mean air temperature decreased with height in the crop, maximum air temperature decreased and minimum air temperature increased. As a result, thermal amplitude decreased with height.

True daily mean air temperature in the crop may be evaluated, through linear regression equations, in function of mean temperature calculated by DEVIET, IAC or extreme temperatures models, from temperature observations in the crop or in the meteorological station. 
.88.

9. IITERATURA CITADA

ALVIM, P. e J.R. HAVIS, 1954. An improved jnfiltration series for studing stomatal opening as illustrated with coffee. Plaht. Physiol. Lancaster, 29: 97-98.

ANSARI, A。Q. e W。E。LOONIS, 1959. Leaf tenperatures. American Journal of Botany. Lancaster, 46: 713-717.

BRASIL. Miristério da Agricultura Escritório de Meteorclogia, 1969. Normais Climatológicas。 Rio de Janeiro, 74p。Vol。 IV。

BRASIL. Fundação Instituto Brasileiro de Geografia e Estatísti ca, 1969. Carta do Brasil. Rio de Janeiro. Folha SF22-R-IV-3。

BURKHOLDER, P.R., 1936. The role of light in the life of plants. Bot。Rev. Lancaster, 2: I-52, 97-Iו<.

CHANG, J.H., 1971. Climate and Agriculture. 2a Ed., Chicago. Aldine Publishing Company 304 p. 
COSTA, A.I. e R. SCHRÖDER, 1956。 o microclima em cafezais naõ sombreados no Estado de São Paulo. Instituta Agronômico de Campinas. Campinas. 131 p. ( 1 a parte).

GATES, D.M., 1965. Heat transfer in plants. Scientific Ameri cano $213: 76-84$ 。

GEIGER, R., 1965. The climate near the ground 4 a Ed.Cambridge. Harvard University Press. $611 \mathrm{p}$.

GODOY, H., 1957. Anuário Meteorológico. Secretaria da Agricul_ tura do Estado de São Paulo. Instituto Agronômico, Cam_ pinas. 85 p.

GOMES, F。P., 1966. Curso de Estatística Experimentel。 3aEd. Pi racicaba, Escola Superior de Agricultura "Luiz de Quei_ roz": $404 \mathrm{p}$.

GRANER, E.A., 1966. Estatística。2a Ed. São Paulo. Edições Me Ihoramentos. 183 po (Biblioteca Agronômica Melhoramen tos)。

HEAT, O.V.S. e B。ORCHARD, 1957. Midday closure of stomata tem perature effects on the minimun intercellular space car bon dioxide concentration. Nature. Iondon, 180: 180 182.

IDLE, D.B॰, 1968. The measurement of apparent surface tempera ture。In: WADSWORTH, R.M., coord. The measurement of environmental factors in terrestrial ecolos. Oxford, Blackwell Scientific Publications, p。 47-57. 
KIRKPATRICK, T.W., 1935. The climates and eco-climates of coffee plantations. Amani, Tanganyika. East African A griculture Research Station. $66 \mathrm{p}$. (Studies on the eco logy of coffee plantations in East African, 1).

IINACRE, E.T., 1964. A note on feature oI leaf ara air tempera tures. AgroNieteorol., Amsterdam, I: 66-72。

NAESTRI, M。 e R。 BARROS, 1975. Ecophysiology of Arabica Coffee. In: ALVIN, P.T., coord. Ecophysiology of troxical cropso. Bahia, Comunication Division of CEPIAC. Vol。 II, p. I36 。

MATTSSON, J.O., 1961. Microclimatic observations ir and above cultivated crops. Lund Studies in Geography. Sweden, The Royal University of Iund。 117 p. (Sér. A. Physical Geopraphy, no 16)。

MOTA, F.S., 1975. Meteorologia Agrícola. São Pauzo, Editora Nobel. 376 p. Biblioteca Rural.

NASCIMENTO, F.J.I., 1973. Estimativa da Formação de Orvalho e Molhamento Foliar em Cafezal (Coffea arabica L.) Não Sombreado. Botucatu, FCIIBB/UNESP. $125 \mathrm{p}$. (Nese de Douto ramerto)。

NOFFSINGER, T.I., 1961. Leaf and air temperature under Havaii conditiones.Pacific Science。 Honolulu, 40: 304-306. 
NUNES, M.A。, J.F. BIERHUIZEN, e C。PLOEGMAN, 1968, Studies on the productivity of coffee. I. Effect of Iight, temperature and $\mathrm{CO}_{2}$ concentration on photosynthesis of Coffea arabica. Acta Bot. Neerl. Amsterdam, 18: 420 424 。

ORTOLANI, A.A., 1973. Contribuição ao Estudo Ecológico da Fer. rugem do cafeeiro (Hemileia vastatrix Berk et Br.) em diferentes populações de Coffea arabica I。 da Região de Pindorama-SP, Brasil. Botucatu, FCMBB/NESP, 9lp。 ( $T$ ese de Doutoramento).

PRIESTLEY, C.H.B., 1966. The Limitation of Temperature by Eva poration in hot Climates. Agr. Meteorol. Aristerdam, 3: $241-246$ 。

ROBLEDO, A.J., 1975. El perfil del viento en cafeteles al sol. Cenicafé. Colombia, 27(3): 143-147.

SANTOS, J.M., E。SALATI e W。R。ACCORSI, 1958. Relatório preliminar das pesquisas realizadas em Campos do Jordão em julho de 1958 relativas ao fenômeno geada e sua influ ência em mudas de cafeeiros e anexos. Campinas, Instituto Agronômico. mimeografado。

SÃO PAULO. Secretaria da Agricultura. Coordenadoria de Assistência Técnica Integral, 1975。Cultura de Café。 Cam pinas. Ed. CATI, $82 \mathrm{p}$. 
SETZER, J., 1946. Contribuicão para o estudo do clima do Esta do de São Paulo. Separata atualizad do Boletim "D.E. R.", vols. IX a XI, outubro de 1943 a outubro de 1945. Escolas Profissionais Salesianas. 239 p.

SHAW, R.H., 1954. Leaf and air temperatures under freezing con ditions. Plant. Physiology. Lancaster, 29: 102-104.

TOSIN, W.A.C., C.R. ESPINDOLA, A.A. PACCOLA e J.I.G. SOUZA。 1973. Levantamento pedológico da Fazenda Experimental Lageado. Boletim Científico do Departamerto de Agrótec nia e Geologia da F.C.M.B.B. Botucatu, ano I, no I, 50 p。

TUBELIS, A., F.J.I. NASCINEENTO e L.I. FOLONI, 1975. Parâmetros cIimáticos de Botucatu - Precipitação e Temperatura do Ar. In: SANTOS, A.J., F.A. DOMINGUES e J.R. PEREIRA. Ed. BOTUCATI-75, Botucatu. p. 14-15.

WEAST, R.C., 1968/69. Handbook of Chemistry and Physics. 49 Ed. Cleveland, The Chemical Rubber Co. p. E I09. 